\title{
COMPORTAMENTO DE ARSÊNIO, FÓSFORO E METAIS PESADOS (CROMO, COBRE, CHUMBO E MERCÚRIO) EM SOLOS EXPOSTOS A CULTIVARES FRUTíFEROS, MUNICÍPIO DE JUNDIAÍ, SÃO PAULO
}

\author{
VALQUIRRIA DE CAMPOS
}

Orientador: Prof. Dr. Raphael Hypolito

TESE DE DOUTORAMENTO

\section{COMISSÃO JULGADORA}

Nome

Presidente: $\quad \operatorname{Prof}^{\text {a. }} \mathrm{Dr}^{\mathrm{a}}$. Lília Mascarenhas Sant'Agostino Examinadores: Prof. Dr. Bernardino Ribeiro de Figueiredo Prof. Dr. Joel Barbujiani Sígolo Prof. Dr. John Edmund Lewis Maddock Prof. Dr. Uriel Duarte

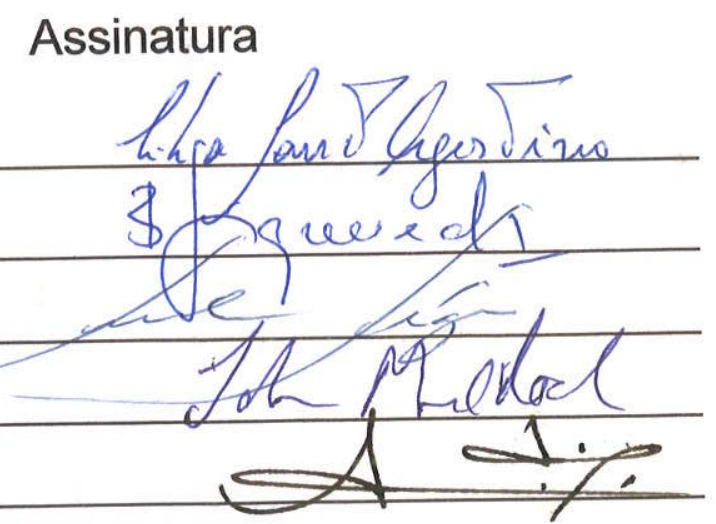

$$
\begin{gathered}
\text { SÃO PAULO } \\
2001
\end{gathered}
$$


UNIVERSIDADE DE SÃO PAULO

INSTITUTO DE GEOCIÊNCIAS

COMPORTAMENTO QUÍMICO DE ARSÊNIO, FÓSFORO E ME'TAIS PESADOS (CROMO, COBRE, CHUMBO E MERCÚRIO) EM SOLOS EXPOSTOS A CULTIVARES FRUTÍFEROS, MUNICÍPIO DE JUNDIAÍ, SÃO PAULO

Valquíria de Campos
Orientador: Prof. Dr. Raphael Hypolito

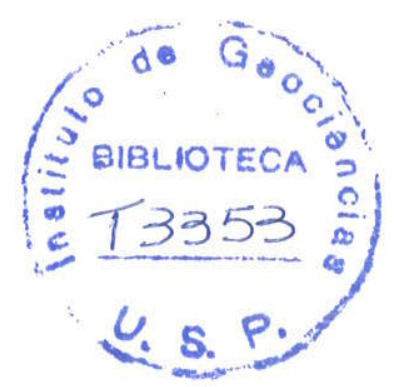

TESE DE DOUTORAMENTO

Programa de Pós-Graduação em Recursos Minerais e Hidrogeologia

São Paulo

2001

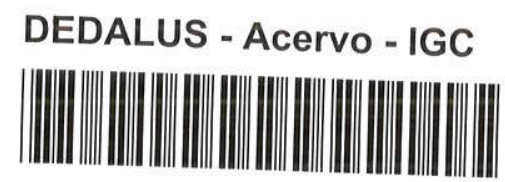

30900007066 


\section{CAMPOS, Valquíria}

Comportamento químico de arsênio, fósforo e metais pesados (cromo, cobre, chumbo e mercúrio) em solos expostos a cultivares frutíferos, Município de Jundiaí, São Paulo / Valquíria de Campos -São Paulo, 2001.

143 p.: il.

Tese (Doutoramento): IGc/USP

Orient.: Hypolito, Raphael

$\begin{array}{lll}\text { 1. Contaminação ambiental } & \text { 2. Agroquímicos } & \text { 3. Arsênio e metais }\end{array}$ pesados I. Título: Comportamento químico de arsênio, fósforo e metais pesados (cromo, cobre, chumbo e mercúrio) em solos expostos a cultivares frutíferos, Municínin de. Iundiaí

DOACAO SECAOAO DE
POS-GRADUACAOO
Data: $15 / 08 / 01$




\section{SUMÁRIO}

Agradecimentos

$i i i$

Lista de figuras $v$

Lista de tabelas ix

Lista de quadros $x i i$

Resumo xiii

Abstract $x i v$

1. Introdução 1

2. Objetivos 4

3. Fósforo, Arsênio e Metais Pesados (Cr, Cu, Pb e $\mathrm{Hg}$ ) 5

Fósforo 6

Arsênio 8

Cromo 13

Cobre 15

Chumbo

Mercúrio 19

4. Materiais e Métodos 21

5. Área de Estudo 27

6. Tratamento e Caracterização de Amostras 32

Rochas

Análise petrográfica e mineralógica 36

Análise química 
Solos

Análise textural

Análise mineralógica

Condutividade hidráulica

CTC e M.O.

$\mathrm{pH}$ 53

Análise química 54

Extrações com água e água/gás carbônico

Água

7. Comportamento Experimental de As e P no Solo 85

8. Caracterização dos Agroquímicos 90

Pesticidas

Calda sulfocálcica 96

Calcário 98

Fertilizantes sintéticos 98

9. Rocha Fosfática

10. Folhas e Frutos

11. Remediação(arsênio em água) 108

12. Conclusões 


\section{AGRADECIMENTOS}

Ao final desta etapa, abrigam-se inúmeros agradecimentos, entre àqueles que, de certa forma, contribuíram para a realização deste trabalho. Faz-se por destacar, no entanto, por sua orientação, o Prof. Dr. Raphael Hypolito.

Ao apoio financeiro da Fundação de Amparo à Pesquisa do Estado de São Paulo FAPESP (Processo n. 97/07129-4), que muito auxiliou para o enriquecimento do trabalho, não só pelos recursos concedidos mas, principalmente, pelas importantes sugestões propostas pelo Relator.

Sr. Antonio Clovis Marquezin e família, do Sítio São Roque, pela paciência e permissão para que pudessemos realizar este trabalho.

Ao Sr. Benedito Rosa e família do Município de Jarinú, onde nasce o Rio Jundiaí-Mirin, agradeço pela amizade.

Ao Engenheiro Isaac Jamil Sayeg do Laboratório de Microscopia Eletrônica de Varredura do Instituto de Geociências da USP, por seu profissionalismo e sugestões.

Ao Geólogo William Sallun Filho pela amostragem de solo, no interior do poço cacimba, destacando-se por sua audácia e coragem para tal feito.

Aos poceiros Carlos e Maurício, não só pelo trabalho efetuado na área de estudo, como também, pelo espírito de equipe.

Ao Dr. Edval Araújo da Escola Politécnica da Universidade de São Paulo, pela contribuição no que diz respeito aos materiais utilizados como adsorventes de arsênio.

Ao Professor Dr. Jose Moacir Vianna Coutinho pelo exame petrográfico das amostras coletadas em campo e, é claro, por sua simpatia.

Ao Geólogo Papa Amadou Gueye, pela amizade e Químico Abdoul Aziz Gueye, ambos do Senegal, pela assistência oferecida na caracterização de rochas fosfáticas.

Aos Professores Dr. Uriel Duarte e Dr. Joel Barbujiani Sígolo pelas críticas e sugestões apresentadas no Exame de Qualificação.

Ao Professor Dr. Bernardino Ribeiro de Figueiredo da Unicamp, agradeço pelo intercâmbio acadêmico proporcionado no correr do Workshop intitulado: "Arsênio e outros resíduos tóxicos da indústria mineral (...)" 
Ao Professor Dr. Jaime Vargas Mello, da UFV-MG, pela simpatia e boas discussões sobre agricultura biodinâmica.

Ao Professor Dr. Paulo César Giannini pela amizade e sugestões nas diversas fases do trabalho.

Ao Químico Nilton Pereira Alves e Raimundo Anchieta Costa do Laboratório Quimlab, pela presteza e agilidade na entrega dos resultados.

A Cerâmica Stéfani em nome do Presidente Sr. Mário Antonio Stéfani, pelo auxílio.

A Höganäs Brasil pelo fornecimento de pó de ferro, utilizado na execução dos ensaios de remediação, Sr. José de Queiroz Lemos e Sra. Sandra Rita Courbassier.

Dra. Débora Teixeira Fávaro do IPEN, pelo auxílio analítico prestado. bibliográfica.

A Maristela Severino, da biblioteca do Instituto de Geociências, pela revisão

Aos colegas do Instituto: Ana Paula e Magali da Seção de Pós-Graudação; Tadeu, Marlene, Brenda, Biotita, Nilva, Maurício, Samuel, Arthur; Sr. Walter e Serginho do CEPAS; Dna. Lourdes e Dna. Mara do Setor de Limpeza; às irmãs Cleide e Sueli; Manuel, Marquinhos e Clodoaldo da Manutenção; Sandra, Marinês, Ricardo, Flávio, Paulinho e João do GMG; Sr. Adalton, Claudionor e Henrique da Gráfica.

Aos colegas da Pós-Graduação: Luciana Ferrer, Alethéa, Shukair, Toni, Carbeny, Paula, Luciana, Márcio, Rolando, Mika, Iraldo, Leandro, Afonso, Sílvia, Sandra, Miriam, Cristiane e Janaína.

Ao Sr. Jamil Sayeg e Sra. Janete Catan Sayeg pelo apoio em todas as fases do trabalho.

Aos meus irmãozinhos Magali e Nestor pelos préstimos, de ordem geral, emocional etc., etc., etc....

Ao meu pai, Luiz Alberto de Campos, parceiro de campo, agradeço por tantas vezes ter carregado as bombas de vácuo "nas costas", mais do que isso, por ter me tranquuilizado e, ao mesmo tempo, me suportado nas tantas horas dificeis que passamos juntos.

A minha mãe, "vovó Lourdinha" e à tia Lú por tudo que fizeram por mim e por Paulina, "meu bebê que cresceu"... 


\section{LISTA DE FIGURAS}

Figura 3.1 Diagrama de pH em função do logarítimo da concentração das diferentes espécies de fosfato.

Figura 3.2 Diagrama de pH e Eh contendo diferentes espécies de arsênio 11

Figura 4.1 Método colorimétrico para determinação de arsênio. 25

Figura 5.1 Mapa de localização da área de estudo, Município de Jundiaí, São Paulo. 28

Figura 5.2 Sítio São Roque, Município de Jundiaí, São Paulo. 29

Figura 5.3 Bacia Hidrográfica do Rio Jundiaí-Mirím. 31

Figura 6.1 Vista geral da área de estudo: a. cultura de pêssego Latossolo; b. Estação Experimental II; c. procedimento de amostragem de água da zona nãosaturada; d. poço de monitoração II. 33

Figura 6.2 Mapa de localização dos pontos amostrados na área de estudo 34

Figura 6.3 Fluxograma de fases no tratamento de amostras de rochas e solos. 35

Figura 6.4 Imagens fotográficas do poço cacimba, durante a coleta de amostras e a perfuratriz utilizada na execução do poço de monitoração II.

Figura 6.5 Resultados de análises granulométricas da Estação I, com profundidade de até $150 \mathrm{~cm}$.

Figura 6.6 Resultados de análises granulométricas da Estação II, com profundidade de até $2200 \mathrm{~cm}$

Figura 6.7 Resultados de análises granulométricas da Estação III, com profundidade de até $1200 \mathrm{~cm}$

Figura 6.8 Diagrama de Classificação Textural de Solos, segundo modelo adotado no Instituto Agronômico de Campinas, com pontos amostrados nas Estações Experimentais. 
Figura 6.9 Resultados de capacidade de troca catiônica em horizontes correspondentes a cada Estação Experimental.

Figura 6.10 Resultados de matéria orgânica em horizontes correspondentes a cada Estação Experimental.

Figura 6.11 Diagrama indicando a concentração de fósforo disponível nas Estações Experimentais.

Figura 6.12 Gráficos representando concentração $\left(\mathrm{mg} \mathrm{kg}^{-1}\right)$ de $\mathrm{Cr}, \mathrm{Cu}$ e $\mathrm{Pb}$ em função da profundidade (cm), na Estação Experimental I

Figura 6.13 Gráficos representando concentração $\left(\mathrm{mg}^{-1} \mathrm{~kg}^{-1}\right)$ de $\mathrm{As}, \mathrm{Cr}, \mathrm{Cu}$ e $\mathrm{Pb}$ em função da profundidade (cm), na Estação Experimental II .59

Figura 6.14 Gráfico representando concentração $\left(\mathrm{mg} \cdot \mathrm{kg}^{-1}\right)$ de $\mathrm{Hg}$ em função da profundidade (cm) na Estação Experimental II

Figura 6.15 Gráficos representando concentração $\left(\mathrm{mg}^{\mathrm{kg}}{ }^{-1}\right)$ de $\mathrm{As}, \mathrm{Cr}, \mathrm{Cu}$ e $\mathrm{Pb}$ em função da profundidade $(\mathrm{cm})$ na Estação Experimental III........................61

Figura 6.16 Gráfico representando concentração $\left(\mathrm{mg} \cdot \mathrm{kg}^{-1}\right)$ de $\mathrm{Hg}$ em função da profundidade $(\mathrm{cm})$ na Estação Experimental III.

Figura 6.17 Resultados analíticos (elementos traço) das soluções finais após extrações com água $\left(\mathrm{mg} \cdot \mathrm{L}^{-1}\right)$

Figura 6.18 Resultados analíticos (elementos traço) das soluções finais após extrações com água e gás carbônico (mg. $\left.\mathrm{L}^{-1}\right)$.

Figura 6.19 Fluxograma de fases no tratamento de amostras em solução.

Figura 6.20 Projeção no Diagrama de Piper, em porcentagem de meq. $\mathrm{L}^{-1}$ das amostras de água do aqüifero, em diferentes meses. .76

Figura 6.21 Precipitação pluviométrica mensal do ano de 1998, na zona rural do Município de Jundaí 78 
Figura 6.22 Resultados analíticos de arsênio, chumbo, cromo e cobre presentes na água de superficie nos meses de abril, maio e julho de 98

Figura 6.23 Resultados analíticos de arsênio, chumbo, cromo e cobre presentes na água da zona não-saturada nos meses de abril, maio e julho de 98

Figura 6.24 Resultados analíticos de arsênio, chumbo, cromo e cobre presentes na água da zona saturada nos meses de abril, maio e julho de 98 .

Figura 7.1 Teores de fosfato e arsenato assimilados em função da concentração de partida.

Figura 7.2 Teores de arsênio assimilados pelo solo em função do aumento da concentração de fósforo

Figura 8.1 Resultados analíticos de arsênio e metais pesados nos pesticidas amostrados no Sítio São Roque

Figura 8.2 Resultados analíticos de arsênio e metais pesados em amostra do enxofre elementar $\left(\mathrm{mg}_{\mathrm{kg}} \mathrm{kg}^{-1}\right)$

Figura 8.3 Resultados analíticos de arsênio e metais pesados dos fertilizantes utilizados na área de estudo.

Figura 9.1 Resultados analíticos de fosforito marinho de Tobene Ouest, com predomínio do mineral crandallita.

Figura 9.2 Resultados analíticos de referência para depósito sedimentar segundo (ICS, 1999)

Figura 9.3 Resultados analíticos do carbonatito de Araxá, Brasil. 104

Figura 9.4 Resultados analíticos do piroxenito de Araxá, Brasil. 105

Figura 11.1 Micrografia eletrônica de varredura dos materiais utilizados na retenção de arsênio: (a) lã de aço; (b) ferro em pó, (c) zinco e (c) carvão ativado 
Figura 11.2 Projeção gráfica dos teores de arsênio adsorvidos em lã de aço, ferro em pó, zinco e carvão ativado.

Figura 11.3 Teores de ferro e zinco em solução, após $1,7,15$ e 30 dias de contato entre lã de aço e zinco com 0,25 mg.L. ${ }^{-1}$ de As............................................118

Figura 11.4 Representação esquemática da vela de filtro utilizada em filtros domésticos, desenho técnico fornecido pela Cerâmica Stéfani. 121 


\section{LISTA DE TABELAS}

Tabela 4.1 Constituintes químicos, métodos analíticos, equipamentos e laboratórios utilizados na determinação de cátions e ânions em amostras naturais e agroquímicos

Tabela 6.1 Composição química de material rochoso procedente das Estações Experimentais I, II e III

Tabela 6.2 Resultados analíticos de arsênio e metais pesados de material rochoso procedente das Estações Experimentais I, II e III

Tabela 6.3 Classificação visual de níveis estudados em cada Estação Experimental, a profundidade é dada em $\mathrm{cm}$

Tabela 6.4 Resultados de análises granulométrica, textural e coloração dos horizontes da Estação I, com profundidade de até $150 \mathrm{~cm}$

Tabela 6.5 Resultados de análises granulométrica, textural e coloração dos horizontes da Estação II, com profundidade de até $2200 \mathrm{~cm}$.

Tabela 6.6 Resultados de análises granulométrica, textural e coloração dos horizontes da Estação III, com profundidade de até $1200 \mathrm{~cm}$

Tabela 6.7 Composição mineralógica da Estação I com amostragem em diferentes níveis de profundidade.

Tabela 6.8 Composição mineralógica da Estação II com amostragem em diferentes níveis de profundidade

Tabela 6.9 Composição mineralógica da Estação III com amostragem em diferentes níveis de profundidade

Tabela 6.10 Resultados do ensaio por condutividade hidráulica com carga variável......48

Tabela 6.11 Resultados de análises, porosidade total $(\eta)$ e condutividade hidráulica saturada $\left(\mathrm{K}_{\mathrm{s}}\right)$

Tabela 6.12 Valores de capacidade de troca catiônica e de matéria orgânica dos solos das Estações Experimentais. 
Tabela 6.13 pH de solo nos horizontes dos perfis estudados: $\mathrm{pH}_{\mathrm{H} 2 \mathrm{O}}$ refere-se a leitura em meio aquoso e $\mathrm{pH}_{\mathrm{KCl}}$ em solução potássica e respectivos $\Delta \mathrm{pH}\left(\mathrm{pH}_{\mathrm{H} 2 \mathrm{O}}-\right.$ $\mathrm{pH}$

Tabela 6.14 Composição química (óxidos) de material terroso procedente das Estações Experimentais I, II, e III, segundo demarcação visual em horizontes com teores expressos em (\%). 54

Tabela 6.15 Resultados analíticos de arsênio e metais pesados encontrados nos solos da Estação Experimental I, a profundidade é dada em $(\mathrm{cm})$. .56

Tabela 6.16 Resultados analíticos de arsênio e metais pesados encontrados nos solos da Estação Experimental II, a profundidade é dada em $(\mathrm{cm})$ .56

Tabela 6.17 Resultados analíticos de arsênio e metais pesados encontrados nos solos da Estação Experimental III, a profundidade é dada em $(\mathrm{cm})$. 57

Tabela 6.18 Resultados analíticos das soluções, produtos das extrações com água (mg.L).

Tabela 6.19 Valores de pH (inicial e final) de soluções resultantes de extrações em soxhlet $\left(\mathrm{H}_{2} \mathrm{O} / \mathrm{CO}_{2}\right)$

Tabela 6.20 Resultados analíticos (elementos traço e fósforo) das soluções finais após extrações com água e gás carbônico (mg. $\left.\mathrm{L}^{-1}\right)$.

Tabela 6.21 Resultados analíticos das águas pluvial, de superfície e aqüífero amostradas em abril de 1998 .68

Tabela 6.22 Resultados analíticos das águas pluvial, de superfície e aqüífero amostradas em maio de 1998

Tabela 6.23 Resultados analíticos das águas pluvial, de superficie e aqüífero amostradas em julho de 1998

Tabela 6.24 Resultados analíticos da água da zona não-saturada amostradas em abril de 1998

Tabela 6.25 Resultados analíticos da água da zona não-saturada amostradas em maio de 1998.

Tabela 6.26 Resultados analíticos da água da zona não-saturada amostradas em julho de 1998 
Tabela 6.27 Limites máximos de tolerância para contaminantes inorgânicos em águas potáveis em mg. $\mathrm{L}^{-1}$

Tabela 6.28 Resultados analíticos da água de chuva em $\left(\mu \mathrm{g} \cdot \mathrm{L}^{-1}\right)$, amostrada nos meses abril, maio e julho de 1998 .

Tabela 8.1 Resultados analiticos dos pesticidas estocados no Sítio São Roque .94

Tabela 8.2 Resultados analíticos de arsênio e metais pesados em amostra de calcário dolomítico.

Tabela 10.1 Resultados analíticos de frutos (polpa e casca) e folhas do pessegueiro (mg. $\mathrm{kg}^{-1}$ ) 106

Tabela 10.2 Limites máximos de tolerância para contaminantes inorgânicos em alimentos em mg. $\mathrm{kg}^{-1}$ 107

Tabela 11.1 Informações gerais sobre processos de tratamento de água para remoção de arsênio 


\section{LISTA DE QUADROS}

Quadro 6.1 Classificação das águas da zona saturada para os meses amostrados, segundo diagrama de Piper

Quadro 8.1 Calendário de aplicação de agroquímicos em culturas de pêssego, no Sítio São Roque

Quadro 8.2 Produtos químicos utilizados nas culturas do Sítio São

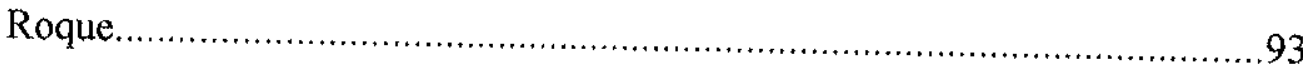

Quadro 11.1 Informações gerais sobre processos de tratamento de água para remoção de arsênio. 


\section{RESUMO}

CAMPOS, V. (2001) Comportamento químico de arsênio, fósforo e metais pesados (cromo, cobre, chumbo e mercúrio) em solos expostos a cultivares frutiferos, Município de Jundiaí, São Paulo. São Paulo, 143 p. Tese (Doutoramento) - Instituto de Geociências, Universidade de São Paulo.

Em áreas agrícolas, o uso indiscriminado de agroquímicos leva ao comprometimento da qualidade ambiental. A aplicação contínua de fertilizantes sintéticos e pesticidas resulta no acréscimo de constituintes tóxicos no solo e, conseqüentemente, na água subterrânea. Estudos realizados em área agrícola de Jundiaí, São Paulo, revelaram presença de teores significativos de arsênio na água dos poços monitorados. A ingestão de arsênio inorgânico pode causar câncer, principalmente, de pele e pulmonar. No solo verificou-se, além de arsênio, a existência de cromo, cobre, chumbo e mercúrio proveniente de produtos químicos utilizados na lavoura. Os produtos químicos utilizados no tratamento de cultivares frutiferos, apresentaram arsênio e metais pesados em sua composição. A adubação fosfatada constitui-se a principal fonte de contaminação de arsênio no solo, em razão da alta dosagem empregada. A presença desse constituinte nos fertilizantes deve-se ao minério fosfático utilizado na produção do adubo químico. A mobilidade de arsênio foi evidenciada com ensaios de competitividade aniônica entre arsenato e fosfato, onde a adsorção de arsenato pelo solo decresce na presença de fosfato. A constatação de arsênio na água levou a realização de experimentos de remediação. A lã de aço foi utilizada na remoção de arsênio (III e V) da água. Assim, como sugestão, para áreas rurais desprovidas de sistema de tratamento de água, recomenda-se o uso de talha terracota contendo, como meio filtrante, de carvão ativado e lã de aço. A principal vantagem desse processo deve-se ao baixo custo e de aplicação residencial. 


\begin{abstract}
This study investigated the occurrence and behaviour of arsenic and heavy metals (chromium, copper, lead and mercury) in the soil. Special attention is given to the anthropogenic impact, such as the effects of agriculture on soil quality and drinking water contamination. Arsenic and heavy metals may accumulate in soil through the application of fertilizers and pesticides. Studies were carried out in an area of Jundiai, São Paulo, with high arsenic in levels natural water from domestic wells. Ingestion of inorganic arsenic can cause skin and lung cancers. The deterioration of soil and groundwater quality as a result mainly of fertilizer use due to excessive $\mathrm{P}$ application, overdosing of soil with phosphate, undesirable additions of arsenic and trace elements. Phosphate fertilizers are a potential source of arsenic. The concentration of arsenic in the fertilizer will vary with the source rock for to produce the synthetic manure. Based on data from the laboratory experiments, arsenate and phosphate sorption, displayed similar adsorption. Nevertheless, arsenate adsorption by soil decreased in the presence of phosphate; thus increasing the mobility of arsenic in the soils. Based on results from laboratory studies, steel-wool was utilized in remotion of arsenic (III and V) from drinking water, because it offer high adsorption capacity. The combination of granular actived carbon and steel-wool can effect. As removal up to $100 \%$. A major advantage of this process is due to the low-cost and residential application (terra cotta filter).
\end{abstract}




\section{INTRODUÇÃO}

A utilização de recursos hídricos subterrâneos vem sendo cada vez mais ameaçada, resultante de impactos advindos de atividades antrópicas. O lançamento in natura de efluentes industriais bem como a intensificação do uso de fertilizantes sintéticos e pesticidas na agricultura têm, em escala cada vez maior, posto em risco a qualidade ambiental.

Em áreas rurais, os problemas decorrentes do uso intenso de agroquímicos continuam a desenhar um quadro de gravidade que diz respeito tanto a intoxicação de trabalhadores expostos aos produtos, como na contaminação ambiental desencadeada pelas aplicações indiscriminadas, muitas vezes, desprovidas de efetiva orientação e acompanhamento técnico. O contato com a temática ambiental ligada ao uso de agroquímicos também depara-se com a qualidade da água e dos alimentos.

A importância e atualidade da questão dos agroquímicos no Brasil, pode ser constatada diante da atenção dada ao tema no documento construído para a "Agenda 21 Brasileira", em especial, no tópico temático dedicado à Agricultura Sustentável.

O documento dedica-se a diagnosticar os problemas decorrentes do uso da tecnologia química, trazendo diretrizes quanto a redução e fiscalização do uso desses produtos, visando o manejo sustentável dos sistemas produtivos. Um dos relatórios produzidos como subsídios à composição da agenda aponta que "não é de se espantar que em torno dos agrotóxicos se desenvolvam as mais acesas polêmicas, quando se trata da relação entre agricultura e meio ambiente. Em primeiro lugar, a magnitude dos interesses em jogo é gigantesca...o setor faturou, em 1997, quase US\$ 2,2 bilhões, sendo US\$ 200 milhões a mais que no ano anterior." (ABRAMOVAY, 1999).

A implantação da prática do que se convencionou chamar de "receituário agronômico", a partir da aprovação da legislação federal (Lei n 7.802 de 11 de julho de 1989) que regulamenta o uso dos agroquímicos no país, representa uma 
tentativa de controle da comercialização e da utilização desses produtos, buscando minimizar os efeitos negativos no meio agrícola (BRASIL, 1989).

A constatação dos problemas gerados pelo consumo de agrotóxicos, torna-se ainda mais evidente ao analisar o contexto da potencialidade dos novos produtos: “... a indústria registra princípios ativos que não serão captados pela capacidade laboratorial existente. As substâcias proibidas continuam a ser monitoradas, mas nunca mais, após 1984, houve a consolidação dos dados estatais a esse respeito"(ABRAMOVAY, 1999; FERREIRA, 1999).

A maioria dos pesticidas agrícolas é constituída por compostos orgânicos, que, além da toxicidade inerente, pode apresentar em sua composição química elementos metálicos nocivos à saúde humana. Nas culturas, a aplicação de macronutrientes como o nitrogênio, fósforo e potássio é uma prática usual, bastante difundida entre os agricultores. Os teores de fósforo comumente aplicados a cada cultivo são superiores àqueles necessários e assimilados pelas plantas, em razão de sua alta retenção pelo solo. O fornecimento de macronutientes, entretanto, pode acarretar também a adição indireta de metais pesados e semi-metais ao solo. Esses produtos podem ser fontes geradoras de elementos contaminantes e o fator de risco acha-se associado à mobilidade desses elementos até aquíferos, comprometendo a qualidade das águas.

O comportamento físico-químico dos metais pesados é influenciado por numerosas propriedades do solo como o pH, textura, composição mineralógica, capacidade de troca catiônica, matéria orgânica, competitividade iônica, temperatura e umidade do solo, além da atividade microbiana. Todos estes fatores controlam a solubilidade química, característica de cada substância e, conseqủentemente, a mobilidade iônica no meio (MARSCHNER, 1995).

$A$ adição de arsênio nas culturas pode ocorrer com o uso de inseticidas contendo arsenato de cálcio $\left[\mathrm{Ca}_{3}\left(\mathrm{AsO}_{4}\right)_{2}\right]$ e arsenato de chumbo $\left[\mathrm{Pb}_{3}\left(\mathrm{AsO}_{4}\right)_{2}\right]$ (WOOLSON et al. 1971). O ácido arsênico $\left(\mathrm{H}_{3} \mathrm{AsO}_{4}\right)$, ácido dimetilarsínico - DMA 
$\left[\left(\mathrm{CH}_{3}\right)_{2} \quad \mathrm{AsO}_{2} \mathrm{H}\right]$ e arsenato de sódio $\left(\mathrm{Na}_{3} \mathrm{AsO}_{4}\right)$ são utilizados como desfoliantes; enquanto o disódio metanoarsonato - DSMA $\left(\mathrm{CH}_{3} \mathrm{AsO}_{3} \mathrm{Na}_{2}\right)$, monosódio metanoarsonato - MSMA $\left(\mathrm{CH}_{3} \mathrm{AsO}_{3} \mathrm{HNa}\right)$ e ácido monometilarsonico - MAA $\left(\mathrm{CH}_{3} \mathrm{AsO}_{3} \mathrm{H}_{2}\right)$ são aplicados como herbicidas (ABERNATHY, 1983; MILLER JUNIOR, 1990; MCCONNELL et al. 1993).

$O$ arsênio pode ser retido no solo por mecanismos de adsorção, principalmente, na presença de argilominerais, óxidos hidratados de $\mathrm{Fe} e$ trihidróxidos de $\mathrm{Al}$ como caulinita $\left[\mathrm{Al}_{2} \mathrm{Si}_{2} \mathrm{O}_{5}(\mathrm{OH})_{4}\right]$, goethita $(\alpha$-FeO.OH) e gibbsita $\left[\gamma-\mathrm{Al}(\mathrm{OH})_{3}\right] . \mathrm{O}$ arsênio, entretanto, também pode manter-se disponivel, mediante a competitividade aniônica como, por exemplo, na presença de $\mathrm{H}_{2} \mathrm{PO}_{4}{ }^{2 *}$.

A reflexão quanto a esta problemática, motivou a realização deste trabalho, ocupando-se do comportamento de arsênio e metais pesados, assim como, da mobilidade e fixação dessas espécies em função das condições químicas e físicoquímicas dominantes em solos agrícolas. Para tanto, escolheu-se uma área de plantio no Município de Jundiaí, considerada exemplar no uso e manejo do solo. 


\section{OBJETIVOS}

Realizar a monitoração de uma área agrícola, contendo cultivares frutíferos, com implicações ambientais diante do uso de agroquímicos.

Estudar o comportamento químico de arsênio, cromo, cobre, chumbo e mercúrio diante de perfil hidríco constituído das zonas não-saturada e saturada; levando em conta a competitividade aniônica entre fosfato e arsenato no solo. A presença desses elementos também será detectada em superfície, nas águas, folhas e frutos.

A presença desses elementos também será determinada em superficie: nas águas, folhas e frutos.

Testar meios de purificação de água para consumo doméstico, buscando atender às necessidades de áreas agrícolas, desprovidas de rede de abastecimento de água. 


\section{FÓSFORO, ARSÊNIO E METAIS PESADOS (Cr, $\mathrm{Cu}, \mathrm{Pb}$ e Hg)}

\section{CONSIDERAÇÕES GERAIS}

A maior parte dos elementos químicos, em particular os metais pesados, tem papel único sobre a saúde humana; alguns são considerados essenciais, pelo menos dentro de certos níveis de ingestão, enquanto outros são considerados tóxicos, em maior ou menor grau, dependendo do elemento e dos níveis ingeridos. Assim, enquanto zinco e cálcio são considerados essenciais; chumbo, cádmio e mercúrio (independente do estado de oxidação) são tóxicos. Já o cromo (VI) e arsênio (III), são reconhecidamente cancerígenos.

Quando em solução, os metais pesados podem sofrer diferentes processos de sorção/reação em partículas sólidas do solo que incluem adsorção, quimiosorção, adsorção e troca iônica, além da formação de complexos com matéria orgânica. Segundo MARSCHNER (1995), os complexos metálicos com ácidos fúlvicos são mais solúveis quando comparados aos ácidos húmicos, por apresentarem alta acidez e pesos moleculares relativamente baixos.

No solo, a aplicação de macronutrientes como o nitrogênio, fósforo e potássio é uma prática freqüente e bastante difundida entre os agricultores. Da mesma forma, o fornecimento de micronutrientes como zinco, manganês e cobre tem em vista o aumento da produção agrícola.

$\mathrm{Na}$ literatura, o termo metal pesado apresenta uma variedade de definições, entretanto, para este estudo considerou-se como metal pesado o elemento químico com densidades superiores a $5 \mathrm{~g} . \mathrm{cm}^{-3}$. Com densidades superiores a $5 \mathrm{~g} . \mathrm{cm}^{-3}$, também pertencem os semi-metais ou metalóides como, por exemplo, o arsênio com $\mathrm{d}=5,72 \mathrm{~g} . \mathrm{cm}^{-3}$ e os não-metais, como o selênio. Os metais pesados são elementos químicos que freqüentemente estão associados à toxicidade e a contaminação de organismos e ambiente. 


\section{FÓSFORO}

O minério fosfático é considerado como principal fonte comercial do elemento fósforo, primordial no desenvolvimento da agricultura mundial. Macronutrientes primários como fósforo, nitrogênio e potássio são essenciais ao crescimento orgânico; quando o solo encontra-se deficiente em relação a esses nutrientes faz-se necessária sua adição para restabelecer a fertilidade. Desta forma, o crescimento da agricultura no mundo depende de forma sensível da disponibilidade de fertilizantes fosfatados. Em 1994, a demanda de rocha fosfática foi de aproximadamente 130 milhões de toneladas, sendo $90 \%$ do montante consumido pela produção de ácido fosfórico e fertilizantes fosfatados (GUEYE, 1998).

De modo geral, os teores de fósforo aplicados a cada cultivo são superiores àqueles necessários e assimilados pelas plantas em razão da alta retenção pelos constituíntes do solo. À medida que entra em solução, o fósforo pode manter-se disponível, móvel ou sofrer fixação.

CAMPOS (1996) verificou experimentalmente que os óxidos hidratados de ferro são os principais responsáveis pela fixação de fósforo em solos de natureza ácida, da mesma forma que adsorvem mais fosfato quando comparados a gibbsita $[\gamma$ $\left.\mathrm{Al}(\mathrm{OH})_{3}\right]$ e caulinita $\left[\mathrm{Al}_{2} \mathrm{Si}_{2} \mathrm{O}_{5}(\mathrm{OH})_{4}\right]$. Por outro lado, em dimensões reduzidas, os minerais na fração argila apresentam-se com elevada superfície específica o que, de certa forma, aumenta o poder de troca iônica. MCBRIDE (1989) considera que a adsorção de fosfato em filossilicatos do tipo 1:1 deve-se ao aparecimento das cargas elétricas diante das faces quebradas e dissociações entre grupos de $\mathrm{Si}-\mathrm{OH}$ e $\mathrm{Al}-\mathrm{OH}$, com as cargas influenciadas pelo $\mathrm{pH}$ do meio. A troca aniônica pode ser resultante da combinação de ânions com íons de ligações rompidas e expostas nas bordas de partículas de argilominerais ou, principalmente, pela substituição de hidroxilas. Os fosfatos apresentam semelhança geométrica (tetraédrica) favorável à ocupação nas 
camadas silicáticas dos argilominerais como, por exemplo, da caulinita que pode reter fosfato de forma praticamente irreversível.

No meio natural, para a maioria dos solos, os valores de $\mathrm{pH}$ ficam entre 3,6 e 10,4. Diante dessa variação, o diagrama de $\mathrm{pH}$ em função do logarítimo da concentração mostra, com boa aproximação, as espécies estáveis nessa faixa de pH.

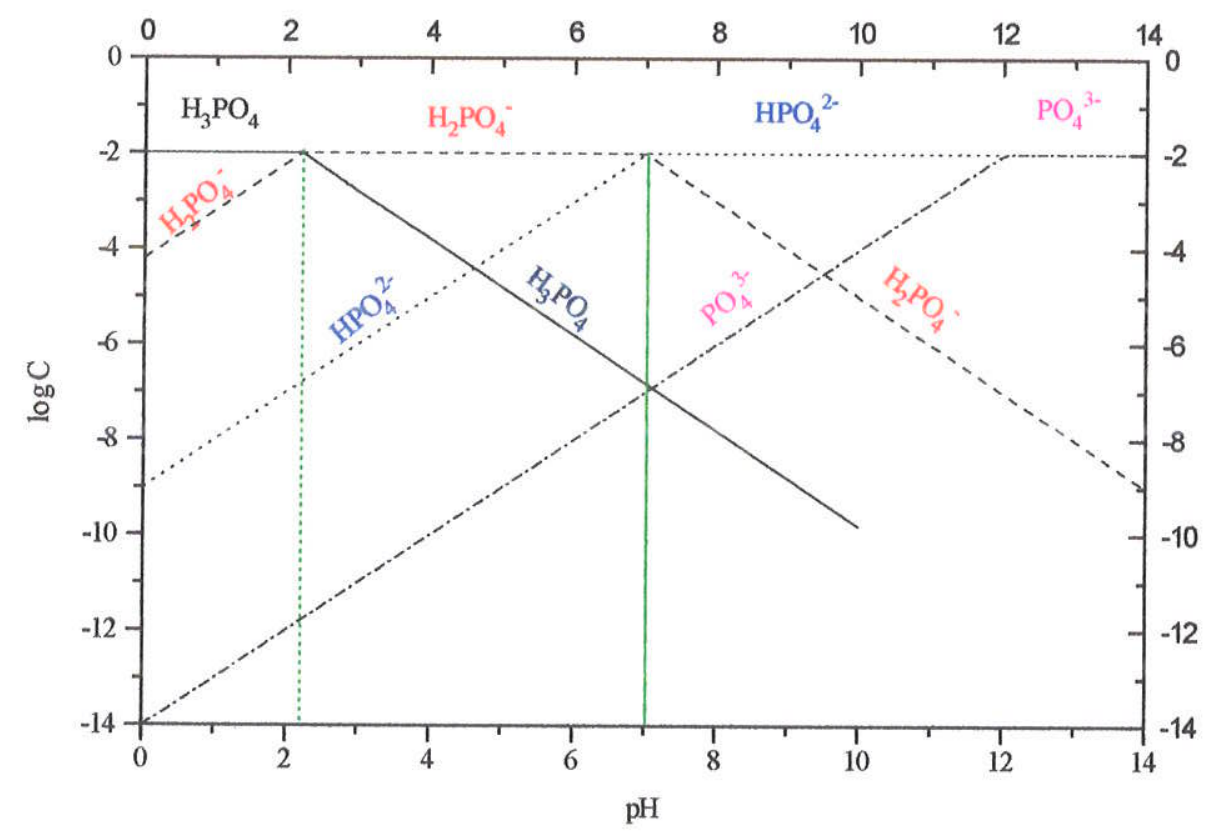

FIGURA 3.1. Diagrama de $\mathrm{pH}$ em função do logarítimo da concentração das diferentes espécies de fosfato 


\begin{abstract}
ARSÊNIO
$\mathrm{O}$ arsênio é encontrado, como elemento traço, em sulfetos como a pirita $\left(\mathrm{FeS}_{2}\right)$, calcopirita $\left(\mathrm{CuFeS}_{2}\right)$, esfarelita $(\mathrm{ZnS})$, galena $(\mathrm{PbS})$ arsenopirita $(\mathrm{FeAsS})$, enargita $\left(\mathrm{Cu}_{3} \mathrm{AsS}\right)$ e tenantita $\left[\left(\mathrm{Cu}_{4} \mathrm{Fe}\right)_{12} \mathrm{As}_{4} \mathrm{~S}_{13}\right]$. Compostos de arsênio, principalmente $\mathrm{As}_{2} \mathrm{O}_{3}$, podem ser obtidos como subproduto da exploração de minérios de cobre, chumbo, zinco, prata e ouro.

A lavra e beneficiamento mineral de depósitos auríferos produzem rejeitos que contêm elementos tóxicos, como o arsênio. $O$ manuseio e a estocagem inadequadas destes rejeitos podem provocar contaminação ambiental e, conseqüentemente, abalar a saúde humana, principalmente quando estes depósitos situam-se próximos a vilarejos (BHUMBLA \& KEEFER, 1994).

A principal aplicação de arsênio é na indústria química e agroindústria, neste caso, utilizado como ingrediente ativo em muitos pesticidas. $\mathrm{O}$ uso de pesticidas iniciou-se com os compostos arseniacais desenvolvidos pelos chineses em 900 d.C. Posteriormente, foram utilizados compostos naturais como nicotina, piretrina e rotenona (MARICONI apud CELESTE 1986).

As atividades humana interferem no acréscimo e distribuição espacial do arsênio, provenientes de processos como combustão de carvão, fundição, refino de metais, produção de zinco e aço, incineração de lixo, mineração etc (CHILVER \& PETERSON, 1987).

Dependendo das condições químicas do meio como $\mathrm{pH}$, potencial redox, e atividade microbiana, o arsênio assume diferentes estados de oxidação com valências + 5 , +3, 0 e -3, $\left(\mathbf{H}_{3} \mathbf{A s O}_{\mathbf{4}}, \mathbf{H}_{3} \mathbf{A s O}_{3}\right.$, $\mathbf{A s}$ e $\mathbf{A s H}_{3}$, respectivamente). Arsênio metálico, arsina $\left(\mathrm{AsH}_{3}\right)$ e formas metiladas de arsênio são termodinamicamente estáveis em sistemas redutores, entretanto o $\mathrm{H}_{2} \mathrm{AsO}_{4}{ }^{-}$e $\mathrm{H}_{3} \mathrm{AsO}_{3}$ predominam em sistemas oxidantes (FERGUSON \& GAVIS, 1972). No solo, quando em solução, a concentração de $\mathrm{H}_{2} \mathrm{AsO}_{4}{ }^{-}$é controlada primeiramente por reações de adsorção sobre
\end{abstract}


óxidos e hidróxidos de ferro, alumínio, e manganês (ANDERSON et al., 1975; OSCARSON et al., 1983; BELZILE \& TESSIER, 1990).

SMITH et al. (1995) relatam que espécies como $\mathrm{H}_{2} \mathrm{AsO}_{4}{ }^{*}$ e $\mathrm{H}_{3} \mathrm{AsO}_{3}$ podem adsorver cátions e sofrer precipitação. Diante de condições ácidas e moderadamente redutoras $(0$ a $0,1 \mathrm{~V})$, o arsenito pode co-precipitar ou ser adsorvido por óxidos hidratados de ferro e manganês. $O$ arsenito também encontra-se presente em sistema aquoso sob condições redutoras e apresenta forte afinidade com enxofre podendo ser adsorvido ou precipitar sob a forma de sulfeto. $O$ arsenito, por sua vez, sofre reações similares de adsorção, embora em menor escala quando comparado ao arsenato (PIERCE \& MOORE, 1982). Os ânions contendo arsênio também exibem vários graus de protonação e de valência que dependem do $\mathrm{pH}$.

Segundo DEUEL \& SWOBODA (1972), o arsenito, sob condições moderadamente oxidantes $(>0,1 \mathrm{~V})$, converte-se em 4 dias em arsenato, enquanto o processo inverso, de arsenato para arsenito, requer várias semanas (TAKAMATSU et al. 1982).

No meio natural, o arsênio é encontrado, principalmente, como $\mathrm{As}^{3+}{\mathrm{e} \mathrm{As}^{5+}}^{5}$. O As (III) é mais solúvel e considerado espécie mais tóxica. O As (V), por sua vez apresenta maior grau de oxidação sendo, normalmente, menos móvel quando comparado ao arsenito. Quando na forma de $\mathrm{H}_{2} \mathrm{AsO}_{4}{ }^{-}$, apresenta comportamento similar ao fosfato, podendo ser adsorvido pelos minerais do solo. A presença de fosfato, especialmente a partir da fertilização química do solo, pode favorecer a competição aniônica entre ambos. Os óxidos e hidróxidos de ferro e alumínio, matéria orgânica e ácidos húmicos contribuem significativamente para retenção de arsênio. Segundo MOK \& WAI (1994), o arsenato em águas superficiais é transportado com o material sólido em suspensão associado a compostos de ferro, alumínio e manganês. Diante do contexto granulométrico, as frações mais finas são as que mostram teores mais elevados de metais adsorvidos. Esses metais normalmente decrescem com o aumento da fração granulométrica. 
A espécie predominante de arsênio em águas de superfície é usualmente o arsenato, entretanto, os microorganismos podem reduzi-lo a arsenito, além de outras formas metiladas. $\mathrm{O}$ arsenato também pode ocorrer em água subterrânea adsorvido em minerais de ferro (WELCH et al. 1988, BHUMBLA et al. 1994). Pode-se, de maneira geral, considerar que os fatores que mais fortemente influenciam esses processos são $\mathrm{pH}$, potencial redox, competitividade aniônica, complexação orgânica, presença de argilominerais e óxidos hidratados, concentração de sulfetos e salinidade, além da distribuição e composição da biota. De acordo com MASSCHELEYN et al. (1991), o arsenato é mais fortemente retido pelos solos quando comparado ao arsenito, diante de processos de adsorção, formando espécies imóveis com minerais contendo $\mathrm{Fe}, \mathrm{Al}, \mathrm{Ca}$ e $\mathrm{Mn}$.

Os campos de estabilidade das principais espécies de arsênio encontram-se no diagrama de $\mathrm{pH}=\mathrm{f}(\mathrm{Eh})$, na figura 3.2 . 


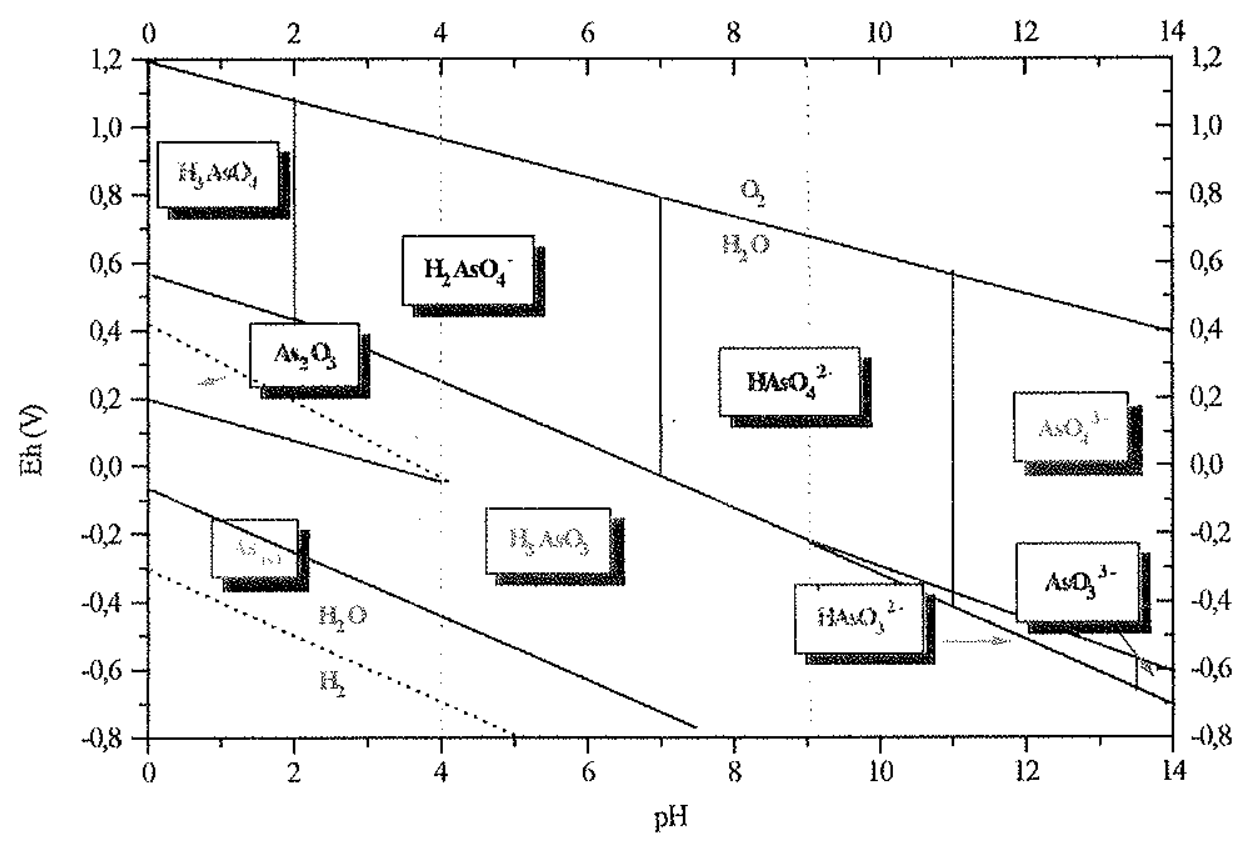

FIGURA 3.2. Diagrama de pH e Eh contendo diferentes espécies de arsênio (BROOKINS, 1988)

$\mathrm{O}$ arsênio apresenta alto grau de toxicidade e ao atingir as águas naturais pode ser ingerido por espécies vivas causando efeitos adversos à saúde humana. (GORBY, 1994). Estudos realizados em Cordoba, na Argentina, registraram alta incidência de mortes entre 1949 e 1959 associada a ingestão de água contendo, em média, $600 \mu \mathrm{g} . \mathrm{L}^{-1}$ de arsênio. Da mesma forma, estudos com a população de Taiwan mostraram correlações entre os niveis de As na água e incidência de câncer (RENZONI et al., 1994). Em Bangladesh e Bengala os habitantes chegam a ingerir água contendo até $2 \mathrm{mg} \cdot \mathrm{L}^{-1}$ e, a partir da década de 80 , começaram a apresentar sintomas visíveis como manchas escuras na pele, verrugas e distúrbios neurológicos 
(FOLHA DE SÃO PAULO, 1998). Em 1984, a WORLD HEALTH ORGANIZATION (WHO) descreveu as manifestações de efeitos clínicos quando da ingestão de arsênio envolvendo os sistema respiratório, gastrointestinal, cardiovascular e nervoso. $O$ arsênio é conhecido pela sua carcinogenicidade e de acordo com INTERNATIONAL AGENCY FOR RESEARCH ON CANCER IARC (1980), o arsênio é enquadrado como substância carcinogênica do grupo 1. A toxicidade do arsênio para o organismo humano pode variar segundo o tipo de exposição, aguda ou crônica (via de absorção) e o tempo total de exposição.

A intoxicação por arsênio causa diversas doenças, além de vários tipos de câncer, principalmente, de pele e pulmonar. Em áreas contaminadas com arsênio, tem sido observado maior número de ocorrências de abortos espontâneos. Os limites de tolerância de arsênio em água para consumo humano tem sido revisado e reduzido no decorrer dos anos. No Brasil, Estados Unidos e Comunidade Européia, a concentração máxima permitida para água doce é de $50 \mu \mathrm{g} . \mathrm{L}^{-1}$. A OMS, por sua vez, recomenda $10 \mu \mathrm{g} . \mathrm{L}^{-1}$ de arsênio em água potável; já a USEPA sugere, para 2001, concentração máxima de $5 \mu \mathrm{g} . \mathrm{L}^{-1}$.

Para CHENG (2000), compostos derivados do arsênio, como o trióxido de arsênio $\left(\mathrm{As}_{2} \mathrm{O}_{3}\right)$, podem inibir fortemente o desenvolvimento de HIV-1 in vitro, aumentando as possibilidades de novas drogas à base de arsênio, no tratamento da AIDS. 


\section{CROMO}

O cromo apresenta-se no meio ambiente em diferentes estados de oxidação, sendo o $\mathrm{Cr}$ (VI) reconhecidamente carcinogênico. Entre os estados de oxidação estáveis, os compostos de $\mathrm{Cr}$ (II) são iônicos e fortemente redutores, oxidando-se a $\mathrm{Cr}$ (III) quando expostos ao ar; o estado (+II) pode ser estabilizado pela formação de complexos. Os compostos de Cr (III) são os mais estáveis; em meio alcalino, contudo, o $\mathrm{Cr}$ (III) oxida-se facilmente a $\mathrm{Cr}$ (VI), tornando-se fortemente oxidante e principal responsável pelos danos à saúde humana (MOORE, 1991; GODGUL et al. 1995). Os sais de cromo hexavalente são largamente utilizados pelas indústrias de couro, tinta, corante, explosivos, papel e cerâmica, além dos processos galvânicos.

Os efeitos negativos do cromo hexavalente sobre o organismo dependem da forma de contato ou via de assimilação. Trata-se de forte agente oxidante, podendo provocar lesões de pele como dermatites, ulcerações e eczemas. No sistema digestivo pode provocar gastroenterocolitese; sobre o sistema respiratório, perfurações de septo nasal, bronquite e asma. A ingestão de cromo pode provocar mutagenicidade (TIGLEA, 1995). O cromo é apontado como agente cancerígeno e de acordo com INTERNATIONAL AGENCY FOR RESEARCH ON CANCER IARC (1980) é enquadrado como substância carcinogênica do grupo 1.

No solo, a maior parte do cromo ocorre na forma de cromo trivalente. Em pH 5,0 é pouco solúvel e seus compostos são muito estáveis, tornando-se móveis em meios muito ácidos. O cromo hexavalente, por sua vez é facilmente mobilizado tanto em solos ácidos como alcalinos. $O$ teor de cromo em solos, principalmente, nas camadas superficiais, tem aumentado devido a diversas fontes poluidoras, como os resíduos gerados por galvanoplastia, curtimento, esgotos domésticos e atividades agrícolas. A presença de fósforo e matéria orgânica tem sido efetiva na redução da mobilidade de cromo em solos contaminados (MATTIAZZO-PREZOTTO, 1994). 
O cromo hexavalente, como os íons cromato $\left(\mathrm{CrO}_{4}{ }^{2-}\right)$ e dicromato $\left(\mathrm{Cr}_{2} \mathrm{O}_{7}{ }^{2-}\right)$ são as espécies mais encontradas. A estabilidade do $\mathrm{Cr}$ (VI) e $\mathrm{Cr}$ (III) depende das condições de Eh e pH. O ion cromato predomina em pH 6 e sob altas condições oxidantes, já o $\mathrm{Cr}^{3+}$ predomina em baixos valores de $\mathrm{pH}$. O Cr (VI) precipita com cátions metálicos como $\mathrm{Ba}^{2+}, \mathrm{Pb}^{2+}$ e $\mathrm{Ag}^{2+}$. A adsorção de $\mathrm{Cr}(\mathrm{VI})$ sobre superfícies de óxidos de ferro e alumínio ocorre somente em $\mathrm{pH}$ ácido ou neutro. $\mathrm{O} \mathrm{Cr}$ (III) é menos tóxico e tende a ser adsorvido sobre argilas em $\mathrm{pH}$ abaixo de 4 . Acima de $\mathrm{pH}$ 5, a imobilidade do cromo é atribuída a formação de $\mathrm{Cr}(\mathrm{OH})_{3}$ e entre $\mathrm{pH} 4$ e 5 ocorrem reações de adsorção e precipitação. O Cr (III) também forma complexos com amônio, sulfato e matéria orgânica, podendo aumentar sua mobilidade (CHROTOWSKI et al. 1991; GODGUL et al. 1995).

O Cr (VI) reduz-se a Cr (III) na presença de ferro (II), compostos orgânicos, particularmente do grupo sulfidril. O Cr (III), por sua vez oxida-se a $\mathrm{Cr}$ (VI) na presença excessiva de $\mathrm{MnO}_{2}$; a oxidação pelo oxigênio ocorre lentamente sob condições naturais da água. 


\section{COBRE}

$\mathrm{O}$ cobre $(\mathrm{Cu})$ encontra-se na natureza no estado elementar, como sulfeto, arsenato, cloreto e carbonato. A forma mais freqüente acha-se no estado de oxidação (II), formando um grande número de sais, a maioria solúvel, além de uma variedade de complexos (GIESY, 1984).

O uso industrial do cobre está associado a muitos setores, entre eles podemos destacar o têxtil, o eletro-eletrônico, o de galvanoplastia e o químico, entre outros. $\mathrm{Na}$ agricultura, os óxidos e sulfatos de cobre têm sido utilizados como adubo e fungicida. No tratamento de água os compostos de cobre são utilizados como algicidas.

O teor de cobre no solo pode variar entre 2 e $100 \mathrm{mg} \cdot \mathrm{kg}^{-1}$, com concentrações médias de 20 a $30 \mathrm{mg} \cdot \mathrm{kg}^{-1}$, como observado em solos provenientes de rochas basálticas. Entre os minérios de cobre, a cuprita $\left(\mathrm{Cu}_{2} \mathrm{O}\right)$ destaca-se por apresentar $88 \%$ do elemento. Segundo MATTIAZO-PREZOTTO (1994), a variação do teor total de cobre em solos do Estado de São Paulo situa-se entre 23 a 126 mg.kg-1 . O cobre normalmente encontra-se na camada superficial do solo, o acúmulo ocorre em consequeência de práticas agrícolas, podendo alcançar teores de até $1500 \mathrm{mg} \cdot \mathrm{kg}^{-1}$.

$\mathrm{O}$ cobre é considerado nutriente para os vegetais e no corpo humano atua como catalisador de reações, além de funções na síntese da hemoglobina oxidando $\mathrm{Fe}^{2+}$ para $\mathrm{Fe}^{3+}$. A ingestão diária de alimentos e água contendo $2 \mathrm{mg} . \mathrm{L}^{-1}$ não deve causar nenhum efeito adverso ao corpo humano, visto que a ingestão inferior a este nível pode ocasionar anemia, neutropenia e desmineralização de ossos em crianças. Em níveis superiores a $5 \mathrm{mg} . \mathrm{L}^{-1}$, o cobre transfere à água coloração particular e sabor amargo desagradável (WORLD HEALTH ORGANIZATION, 1999).

$\mathrm{O}$ cobre, a exemplo de outros metais, normalmente encontra-se em concentrações muito baixas em corpos aquáticos, em níveis próximos a $10 \mu \mathrm{g} . \mathrm{L}^{-1}$ 
(COMPANHIA DE SANEAMENTO BÁSICO DO ESTADO DE SÃO PAULO, 1994). No entanto, em ambiente aquático o elemento pode apresentar-se tóxico devido ao fato de ser bioacumulável. Em peixes é absorvido principalmente pelas mucosas da brânquias e nas algas pelas células superficiais, podendo inibir mecanismos enzimáticos (GARDNER \& RAVENSCROFT, 1991). 


\section{CHUMBO}

O chumbo $(\mathrm{Pb})$ apresenta estados de valência 2 e 4 , sendo $\mathrm{Pb}^{2+}$ a forma mais comumente encontrada. Este elemento ocorre na crosta em concentração média de $14 \mathrm{mg} \cdot \mathrm{kg}^{-1}$ e no solo o teor estimado é de $29 \mathrm{mg} \cdot \mathrm{kg}^{-1}$ (SALOMONS \& FÖRSTNER, 1984). O enriquecimento de chumbo ocorre por atividades relacionadas à mineração, indústria e agricultura.

No solo, os teores de $\mathrm{Pb}$ podem ser acrescidos a partir do emprego de agroquímicos. Segundo KABATA-PENDIAS \& PENDIAS (1984), concentrações naturais de chumbo nas camadas superficiais variam de 3 a $189 \mathrm{mg} \cdot \mathrm{kg}^{-1}$, enquanto a maioria dos valores está entre 10 a 67 e a média de $32 \mathrm{mg} \cdot \mathrm{kg}^{-1}$. Para a COMPANHIA DE SANEAMENTO BÁSICO DO ESTADO DE SÃO PAULO CETESB (1999), altas concentrações de chumbo, acima de $100 \mathrm{mg} \cdot \mathrm{kg}^{-1}$, refletem os efeitos de poluição ambiental. A CETESB estabelece $70 \mathrm{mg} \cdot \mathrm{kg}^{-1}$ como limite superior à concentração de chumbo em solos.

O chumbo é fortemente retido no solo e muito pouco é transportado até a zona de saturação. Em condições de $\mathrm{pH} 6$ a 8 , o chumbo precipita-se na forma de carbonato $\left(\mathrm{PbCO}_{3}\right)$, fosfato $\left(\mathrm{PbPO}_{4}\right)$ e sulfato $\left(\mathrm{PbSO}_{4}\right)$, formando compostos de baixa solubilidade, embora o sulfato de chumbo seja espécie mais solúvel quando comparado a carbonato e fosfato. $\mathrm{O}$ chumbo também pode formar complexos estáveis com compostos inorgânicos $\left(\mathrm{Cl}^{-}, \mathrm{CO}_{3}{ }^{2-}\right)$ e orgânicos (ácidos húmico e fúlvico) tanto nos solos quanto em ambiente aquático. Em pH de 4 a 6 , complexos orgânicos contendo chumbo podem ser lixiviados (SMITH et al. 1995).

Como a maioria dos metais pesados, o chumbo pode causar sérios riscos à saúde humana. $O$ chumbo tende a se acumular no organismo no sistema nervoso central. Os sintomas causados pela ingestão ou inalação de chumbo estão relacionados a perda de apetite, anemia, dor de cabeça, irritação e insônia. O efeito 
mais pronunciado ocorre em crianças, com a redução do desenvolvimento e a performance intelectual. A exposição do chumbo geralmente ocorre por inalação do ar atmosférico, por ingestão de alimentos (principalmente, vegetais e frutas) e água que esteja contaminada pelo elemento (BUENO, 1999).

Segundo WORLD HEALTH ORGANIZATION (1995), o homem ingere teores próximos a $2 \mathrm{mg} \cdot \mathrm{L}^{-1}$ de $\mathrm{Pb}$ diariamente. Uma vez no organismo humano, sua eliminação ocorre através da urina, unhas e cabelos. De modo geral, os efeitos do chumbo sobre a saúde humana dependem da intensidade e duração à exposição, sendo as crianças mais vulneráveis quando comparadas aos adultos. Segundo UNITED STATES ENVIRONMENTAL PROTECTION AGENCY - USEPA (1999), estudos em seres humanos não demonstraram a possibilidade do chumbo causar câncer, entretanto pesquisas em ratos revelam a relação entre a ingestão de altas doses do metal e o desenvolvimento de tumores. 


\section{MERCÚRIO}

Naturalmente, o mercúrio ocorre associado a outros elementos, sendo mais comum com o enxofre formando o mineral cinábrio (HgS). Outras contribuições naturais são provenientes de erupções vulcânicas e minas de mercúrio, sendo responsáveis pela emissão de até 6000 t.ano ${ }^{-1}$ (CLARKSON apud CANELA 1995).

A intervenção antrópica pode ocorrer mediante a queima de combustíveis fósseis, na produção de cloro-soda e de acetaldeído, incinerador de lixo, polpa de papel, tinta, pesticida, mineração de ouro, entre outros. Em função dessas atividades estima-se a emissão de mercúrio emitidas para atmosfera em 3000 t.ano ${ }^{-1}$. No total, mais de 200000 toneladas de $\mathrm{Hg}$ foram emitidas para atmosfera desde 1890, com $95 \%$ retido em solos, $3 \%$ nas águas oceânicas e $2 \%$ na atmosfera (OSA, 1994). O mercúrio elementar apresenta alta volatilidade, permitindo uma atmosfera saturada em concentrações de $18 \mathrm{mg} \cdot \mathrm{m}^{-3}$ a temperatura de $24^{\circ} \mathrm{C}$, favorecendo a disseminação do metal nos diversos compartimentos ambientais (PORCELLA et al. 1995).

A acumulação de mercúrio nos solos é controlada principalmente pela formação de complexos orgânicos. Assim, a mobilidade de $\mathrm{Hg}$ requer processos de dissolução e degradação biológica de componentes organomercuriais (KABATAPENDIAS \& PENDIAS, 1984). Na camada superficial do solo, o mercúrio pode também ser volatizado para atmosfera, reação mediada por bactérias presentes no solo, esse processo é condicionado pela espécie química presente, temperatura e constituição textural do solo, geralmente as perdas por volatilização ocorrem em solos com textura arenosa (PORCELLA et al. 1995).

$\mathrm{O} \mathrm{Hg}_{2}{ }^{2+} \mathrm{e} \mathrm{Hg}^{2+}$ sob condições oxidantes são formas mais estáveis do mercúrio metálico. Diante de condições moderadamante redutoras, ambas espécies orgânicas e inorgânicas podem reduzir-se $\mathrm{Hg}^{0}$ que, por sua vez converte-se rapidamente para 
metil ou etil-mercúrio, através de processos bióticos e abióticos. Metil e etilmercúrio são formas muito tóxicas. O mercúrio (II) pode formar complexos com $\mathrm{Cl}^{-}$, $\mathrm{CO}_{3}{ }^{2-}, \mathrm{SO}_{4}{ }^{2-}, \mathrm{F}^{*}, \mathrm{Br}^{-}, \mathrm{I}^{-}, \mathrm{S}^{2-}$ e $\mathrm{PO}_{4}{ }^{3-}$.

$\mathrm{O} \mathrm{Hg}$ no meio aquático pode ocorrer na forma orgânica e inorgânica. $\mathrm{Na}$ forma inorgânica encontra-se sob três estados de oxidação: o mercúrio elementar $\left(\mathrm{Hg}^{0}\right)$, principalmente na forma de gás; o mercúrio (I) $\left(\mathrm{Hg}_{2}{ }^{2+}\right)$, pouco estável em meio natural e o íon mercúrio (II) $\left(\mathrm{Hg}^{2+}\right)$. Na forma orgânica, como metilmercúrio, dimetilmercúrio e fenilmercúrio além de ligantes orgânicos naturais (TÜMPLING et. al. 1993). O metilmercurio é a espécie predominante em $\mathrm{pH}$ ácido, enquanto em condições alcalinas, o principal composto é o dimetilmercúrio que, por causa de sua volatilidade e baixa hidrossolubilidade é facilmente perdido na interface água/ar.

A toxicidade do mercúrio depende das diferentes espécies existentes no meio natural. A espécie orgânica é extremamente tóxica para o organismo humano e toda biota, entrando rapidamente na corrente sangüínea, causando danos irreparáveis ao sistema nervoso central. Em incidentes por intoxicação, constatou-se que a vida intrauterina é mais suscetível aos danos cerebrais causados pelo metilmercúrio, uma vez que parece interferir nos processos de divisão celular. O mercúrio elementar evidencia baixa toxicidade, no entanto, na forma de vapor, como é liberado na maior parte em garimpos de ouro é absorvido pelo organismo humano através dos pulmões. SILVA (1994) constatou em casos de exposição severa do feto, má formação cefálica, além da clara transferência do mercúrio da mãe. 


\section{MATERIAIS E MÉTODOS}

$\mathrm{Na}$ área de estudo foram coletadas amostras de rocha, solo, água, folhas e frutos, além de fertilizantes sintéticos e pesticidas, sendo caracterizados quimicamente quanto aos teores de metais pesados e arsênio.

Para minimização dos erros analíticos no correr dos experimentos, foram realizadas determinações em paralelo. Os resultados analíticos representam valores médios de duas ou três determinações.

$\mathrm{A}$ análise química das rochas foi efetuada por fluorescência de raios $\mathrm{X}$ Phillips WDS PW2404 pelo método TBL na Escola Politécnica.

As análises de rochas fosfáticas foram concedidas pela "Industries Chímiques du Sénégal" e os íons determinados por Espectrometria de Absorção Atômica Varian AA - 1475; o mercúrio inorgânico foi determinado com uso de Gerador de Hidretos Varian VGA - 76.

Para monitoração da zona não-saturada, foram instalados lisímetros de sucção da Apager. A pressão de sucção foi aplicada por bomba de vácuo da Tecnal TE-058.

As amostras indeformadas foram coletadas com Amostrador de Uhland e submetidas a ensaios de condutividade hidráulica no Laboratório de Física do Solo do Instituto de Pesquisas Tecnológicas. O amostrador de Uhland, equipamento composto por sistema de percussão e cilindro amostrador, possibilita a retirada de amostras sem destruir a estrutura do solo.

As análises granulométricas por pipetagem e peneiramento foram realizadas no Laboratório de Geoquímica do Instituto de Geociências da USP.

A capacidade de troca catiônica (CTC) foi realizada pelo método de GILLMAN (1979) e a matéria orgânica (M.O.) pelo método de WALKLEY \& BLACK (1934), realizados no Laboratório de Ciência do Solo da Escola Superior de Agricultura "Luiz de Queiroz". 
$\mathrm{O}$ fósforo disponível, na forma de $\mathrm{P}_{2} \mathrm{O}_{5}$, foi determinado por extração com resina trocadora Amberlite IR-420 (RAIJ \& QUAGGIO, 1983).

A condutividade hidráulica $(\mathrm{K})$ foi determinada no campo (método de carga variável) e laboratório (método de carga constante).

As águas destinadas às análises químicas foram filtradas em membrana de acetato de celulose $(0,45 \mu \mathrm{m})$ da Millipore, aciduladas com $0,2 \%$ de $\mathrm{HNO}_{3}$ (conforme recomendação do. Activation Laboratories Ltd) e refrigeradas a $4{ }^{\circ} \mathrm{C}$.

Os parâmetros como pH e Eh foram medidos com potenciômetro Digimed DM 21, após calibrações com tampões 4,00 e 7,00 para pH e 97 e $263 \mathrm{mV}$ (quinidrona) para $\mathrm{Eh}$. A condutividade elétrica foi lida em aparelho Orion 295, com sensor de temperatura normalizando as medidas para $25^{\circ} \mathrm{C}$. As leituras foram efetuadas após 2 minutos, para garantir a temperatura da solução medida.

A coleta de águas pluviométricas foi efetuada através de um coletor de deposição total, de construção caseira.

Para medição do nível d'água, utilizou-se medidor manual elétrico com dispositivo luminoso, construido no Instituto de Geociências da Universidade de São Paulo.

Os pesticidas foram analisados no Instituto de Química da Universidade de São Paulo por Espectrometria de Absorção Atômica Spectro Flame.

O calcário dolomítico, procedente da Minercal Agrícola, foi analisado quanto aos teores de metais pesado e metalóide.

$\mathrm{Na}$ determinação de arsênio em enxofre, utilizou-se para abertura de amostra o método proposto pela BRITISH PHARMACOPOEIA (1973), que consiste no aquecimento, em banho-maria, de $5 \mathrm{~g}$ de enxofre, com precisão de quatro casas, por 60 minutos em solução de $\mathrm{NH}_{4} \mathrm{OH}$. Após o período, a solução foi filtrada e o sólido tratado com solução de $\mathrm{Na}_{2} \mathrm{CO}_{3}$, em constante agitação e aquecimento, adicionandose, gota-a-gota, solução $\mathrm{Br}_{2}$ até coloração amarela. A solução foi acidulada e o 
excesso de bromo removido com adição de $\mathrm{SnCl}_{2} \cdot 2 \mathrm{H}_{2} \mathrm{O}$. Para determinação de metais pesados, o enxofre foi calcinado a $300^{\circ} \mathrm{C}$ e o resíduo (cinzas) solubilizado para análise via absorção atômica.

No Instituto Adolfo Lutz realizaram-se análises em folhas e frutos do pessegueiro com determinações de arsênio e metais pesados. As determinações de cobre, cromo e chumbo foram realizadas por Espectrofotometria de Absorção Atômica com Chama da Perkin Elmer 3110. Para arsênio e mercúrio, as amostras foram tratadas por via úmida $\mathrm{e}$ as leituras realizadas por Espectrofotometria de Absorção Atômica Perkin Elmer 3110 com sistema de injeção em fluxo - FIAS 200.

Arsênio e cromo foram determinados, em todas amostras, como constituintes totais.

No estudo experimental de remediação do arsênio em água para consumo humano utilizou-se, como material adsorvente, o ferro em pó Triffer DS $205(\phi \mathrm{m}=$ $97 \mu \mathrm{m}$ ), fornecido pela Höganäs; a lã de aço obtida no comércio e zinco granular p.a da Merck. $O$ carvão ativado granular e vela filtrante foram fornecidos pela Cerâmica Stéfani S.A, localizada no Município de Jaboticabal.

A determinação de ferro e zinco das águas purificadas foi realizada por espectrometria de Absorção Atômica de Chama (Varian AA 1475).

Os constituintes químicos, métodos empregados, equipamentos e Laboratórios foram reunidos na tabela 4.1. No corpo do trabalho, são indicados os limites de deteç̧ão e quantificação. 
TABELA 4.1 - Constituintes químicos, métodos analíticos, equipamentos e laboratórios utilizados na determinação de cátions e ânions em amostras naturais e agroquímicos

\begin{tabular}{|c|c|c|c|}
\hline ion & método & equipamento & laboratório \\
\hline $\mathrm{Na}^{+}$ & ICP-MS & Perkin Elmer Elan 6000 & ACTLABS \\
\hline $\mathbf{K}^{+}$ & ICP-MS & Perkin Elmer Elan 6000 & ACTLABS \\
\hline $\mathrm{Ca}^{2+}$ & ICP-MS & Perkin Elmer Elan 6000 & ACTLABS \\
\hline $\mathbf{M g}^{2+}$ & ICP-MS & Perkin Elmer Elan 6000 & ACTLABS \\
\hline $\mathbf{A} \mathbf{s}_{(t)}$ & ICP-MS & Perkin Elmer Elan 6000 & ACTLABS \\
\hline $\mathbf{A s} \mathbf{s}_{(t)}$ & Colorimetria & HP $8451 \mathrm{~A}$ & QUIMLAB \\
\hline$C \mathbf{r}_{(t)}$ & ICP-MS & Perkin Elmer Elan 6000 & ACTLABS \\
\hline $\mathbf{C r}_{(t)}$ & AAS & Varian AA1475 & QUIMLAB \\
\hline $\mathrm{Cu}^{2+}$ & ICP-MS & Perkin Elmer Elan 6000 & ACTLABS \\
\hline $\mathrm{Cu}^{2+}$ & AAS & Varian AA1475 & QUIMLAB \\
\hline $\mathbf{P b}^{2+}$ & ICP-MS & Perkin Elmer Elan 6000 & ACTLABS \\
\hline $\mathbf{P b}^{2+}$ & AAS & Varian AA1475 & QUIMLAB \\
\hline $\mathbf{H g}^{2+}$ & ICP-MS & Perkin Elmer Elan 6000 & ACTLABS \\
\hline \multirow[t]{2}{*}{$\mathrm{Hg}^{2+}$} & CVAAS & Gerador de Vapor Perkin & QUIMLAB \\
\hline & & Elmer & \\
\hline $\mathrm{Cl}^{-}$ & Cromatografia Î́nica & Dionex DX100 & ACTLABS \\
\hline $\mathrm{SO}_{4}{ }^{2-}$ & Cromatografia Íônica & Dionex DX100 & ACTLABS \\
\hline $\mathrm{PO}_{4}{ }^{3-}$ & Cromatografia Íônica & Dionex DX100 & ACTLABS \\
\hline $\mathrm{NO}_{3}^{-}$ & Cromatografia lônica & Dionex DX100 & ACTLABS \\
\hline $\mathrm{HCO}_{3}^{-}$ & Alcalinidade & Titulação com $\mathrm{H}_{2} \mathrm{SO}_{4}$ & CAMPO \\
\hline
\end{tabular}
Absorção Atômica com Vapor Frio); ICP-MS (Espectrometria de Massa com Plasma Indutivamente Acoplado) 
$\mathrm{O}$ arsênio total foi determinado por espectrometria na forma de arsina $\left(\mathrm{AsH}_{3}\right)$, a partir da dissolução de $\operatorname{AgSCSNC}\left(\mathrm{C}_{2} \mathrm{H}_{5}\right)_{2} \mathrm{em} \mathrm{C}_{5} \mathrm{H}_{5} \mathrm{~N}$. Na figura 4.1 é apresentado esquema do dispositivo utilizado para esta determinação.

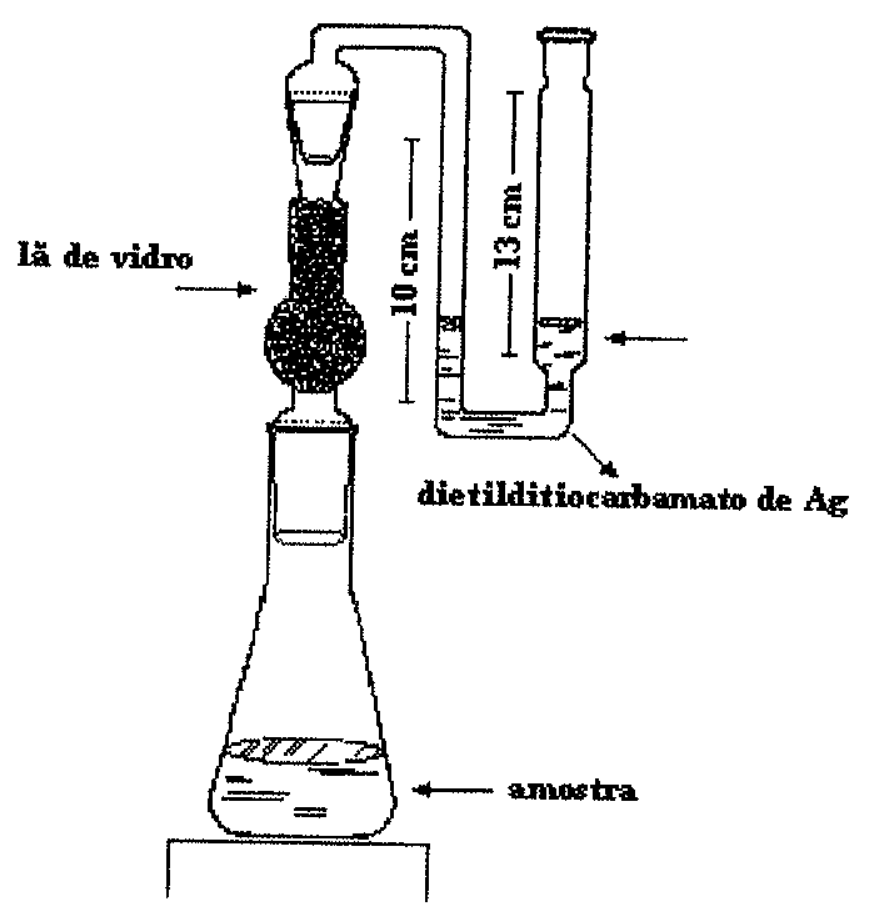

FIGURA 4.1. Método colorimétrico para determinação de arsênio, modificado de AGGET \& ASPELL (1976) 
Os difratogramas de raios $\mathrm{X}$ foram obtidos mediante difratômetro Siemens $\mathrm{D}$ 5000, com apoio de software de identificação mineralógica Eva 2.0.

As análises de morfologia de superficie dos materiais foram efetuadas em microscópio eletrônico de varredura, modelo $440 \mathrm{i}$ da Léo, no Laboratório de Microscopia Eletrônica de Varredura do Instituto de Geociências da USP.

O Mapa de Localização dos Pontos Amostrados - Sítio São Roque (1:1000) foi efetuado em software Arcview 3.0. 


\section{5. ÁREA DE ESTUDO}

A área de estudo foi escolhida no Município de Jundiaí, por apresentar uma zona rural de grande expressividade. Jundiaí localiza-se às margens da rodovia Anhangüera (SP-330), distante $60 \mathrm{~km}$ da Capital de São Paulo (figura 5.1). A Toca, porção nordeste do Município, é um bairro tradicional de imigrantes italianos ligados a lavoura e a viticultura. A partir da década de 80 , muitos agricultores diversificaram suas produções para linha mais ampla de frutas de mesa, orientados por um regime econômico voltado à comercialização de seus produtos. Para compor um quadro mais próximo da realidade fundiária da zona rural de Jundiaí, segundo o tamanho dos estabelecimentos, nota-se o predomínio de pequenas propriedades (20 ha), representando $74 \%$ da área total do município.

O trabalho de campo foi desenvolvido, no ano de 1998, no Sítio São Roque pertencente a A.C. Marquezin. O sítio foi recomendado pela Casa da Agricultura por tratar-se de propriedade muitas vezes envolvida em projetos experimentais com o Instituto Agronômico de Campinas e Escola Técnica de Agricultura, ambos em Jundiaí. No local, desenvolvem-se atividades ligadas à fruticultura, onde observa-se a crescente preocupação do agricultor no sentido de aplicar de maneira racional os agroquímicos, seguindo sempre as recomendações técnicas da Casa da Agricultura. Os resultados apresentados neste trabalho conduzem a um diagnóstico de campo dentro do sistema convencional de manejo do solo. 


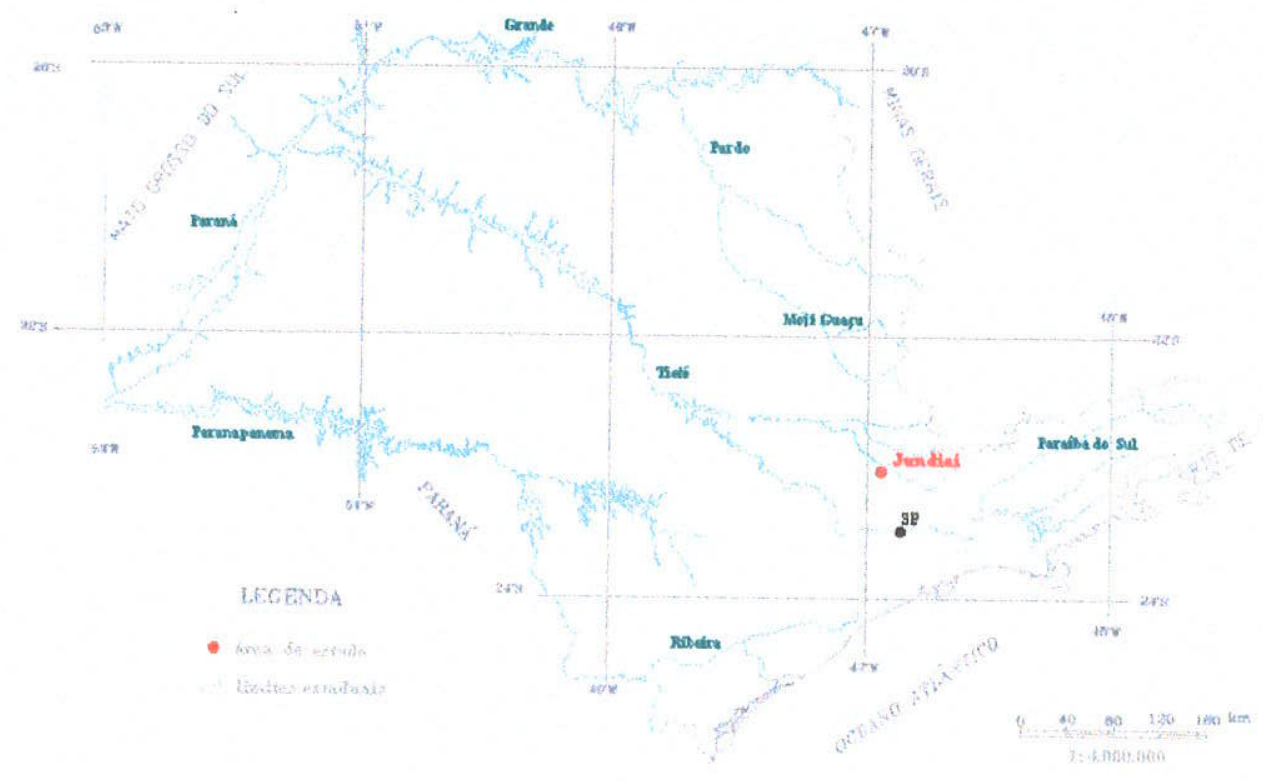

FIGURA 5.1. Mapa de localização da área de estudo, Município de Jundiaí, São Paulo (EVANS, 1996)

A área de estudo pertence ao Planalto de Jundiaí, com predomínio de morros em forma de "meia laranja", com topos arredondados e perfis convexos. O clima apresenta variações ligadas à altitude e ao relevo, refletindo na distribuição das chuvas e oscilações de temperatura. O clima é classificado como "tropical de altitude" com verões chuvosos, invernos relativamente secos e temperaturas de verão abrandadas pela altitude. As temperaturas médias nos meses de verão são de $22{ }^{\circ} \mathrm{C}$ e para os meses de inverno em torno de $17^{\circ} \mathrm{C}$. A precipitação média anual varia entre 1300 a $1500 \mathrm{~mm}$, com umidade relativa do ar próximo de $74 \%$ (GOVERNO DO ESTADO DE SÃO PAULO, 1986). 
No sítio São Roque, a área em estudo corresponde a 6,0 ha e estima-se a produção de 4000 pés de uva, 1600 pés de pêssego além de 200 pés de nectarina e ameixa. Nesse local, aréa de experimentação para culturas, foram instalados equipamentos tendo em vista a monitoração das zonas saturada e não-saturada além das águas atmosférica e superficial.

A área de estudo é constituída por Latossolo Vermelho-Amarelo e Cambissolo Háplico (GOVERNO DO ESTADO DE SÃO PAULO, 1999), distribuídos ao longo da encosta frontal. A área ensaiada, no sítio São Roque, situase em encosta de morrote, com declividade maior que $12 \%$ (figura 5.2).

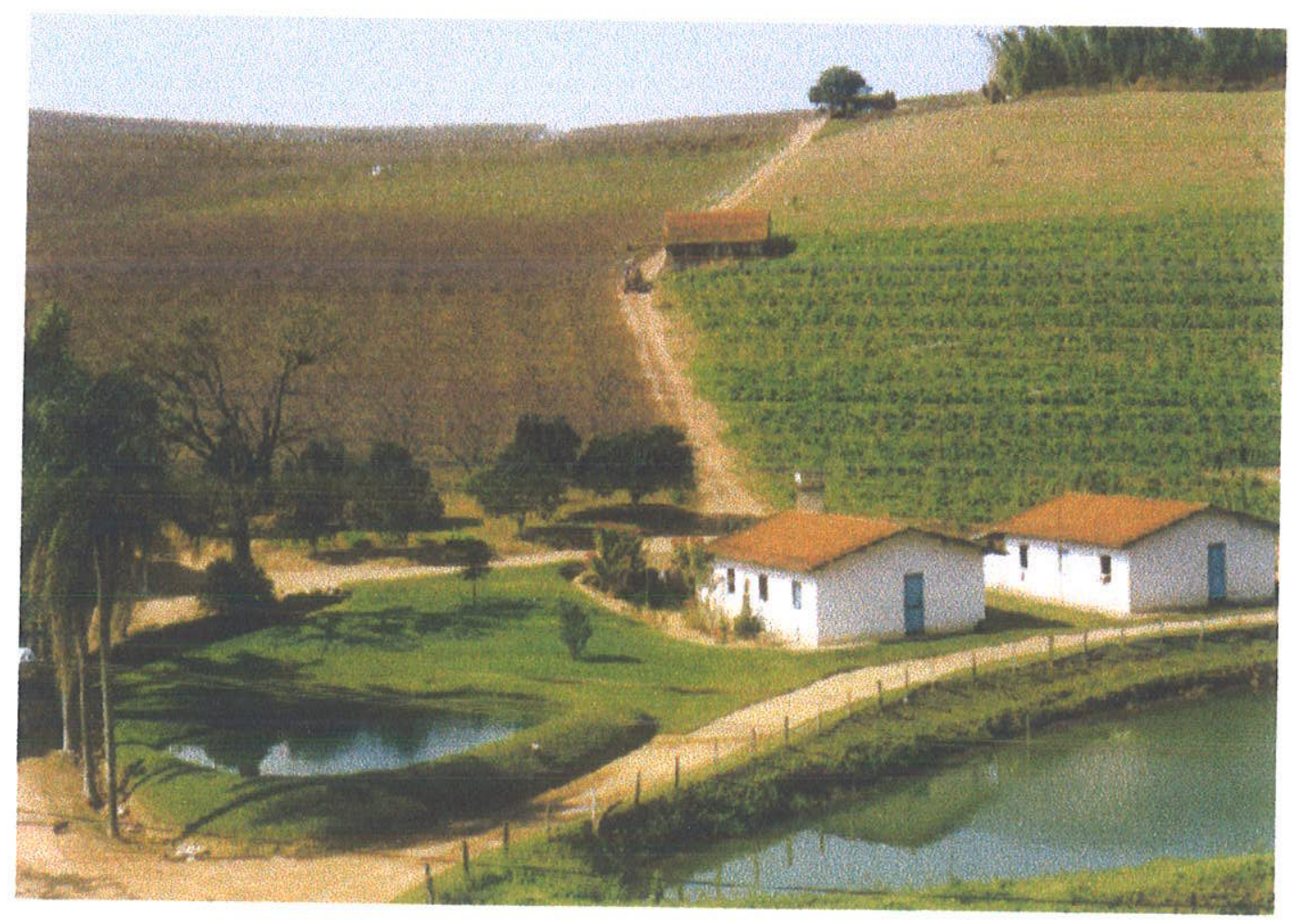

FIGURA 5.2. Sítio São Roque, Município de Jundiaí, São Paulo 
A área de estudo pertence ao Sistema Aqǘfero Cristalino, no domínio das rochas cristalinas do Embasamento Pré-Cambriano. O Aqüífero Cristalino, cujas altitudes máximas de seus divisores situam-se entre 800 e 1000 metros, é formado por duas unidades de características hidrogeológicas distintas. A unidade hidrogeológica da área corresponde ao aqüífero de manto de alteração, de natureza livre, apresentando espessura média da ordem de 25 metros. Neste trabalho, não foi investigada a possibilidade de ocorrência como aqǘfero fraturado.

$O$ local de estudo pertence a Bacia Hidrogeológica do Jundiai-Mirim, afluente do rio Jundiai pela sua margem direita e principal manancial de abastecimento de água do município (figura 5.3). Da nascente até a foz, o rio Jundiaí percorre cerca de $120 \mathrm{~km}$ até a confluência com o rio Tietê, no Município de Salto. 


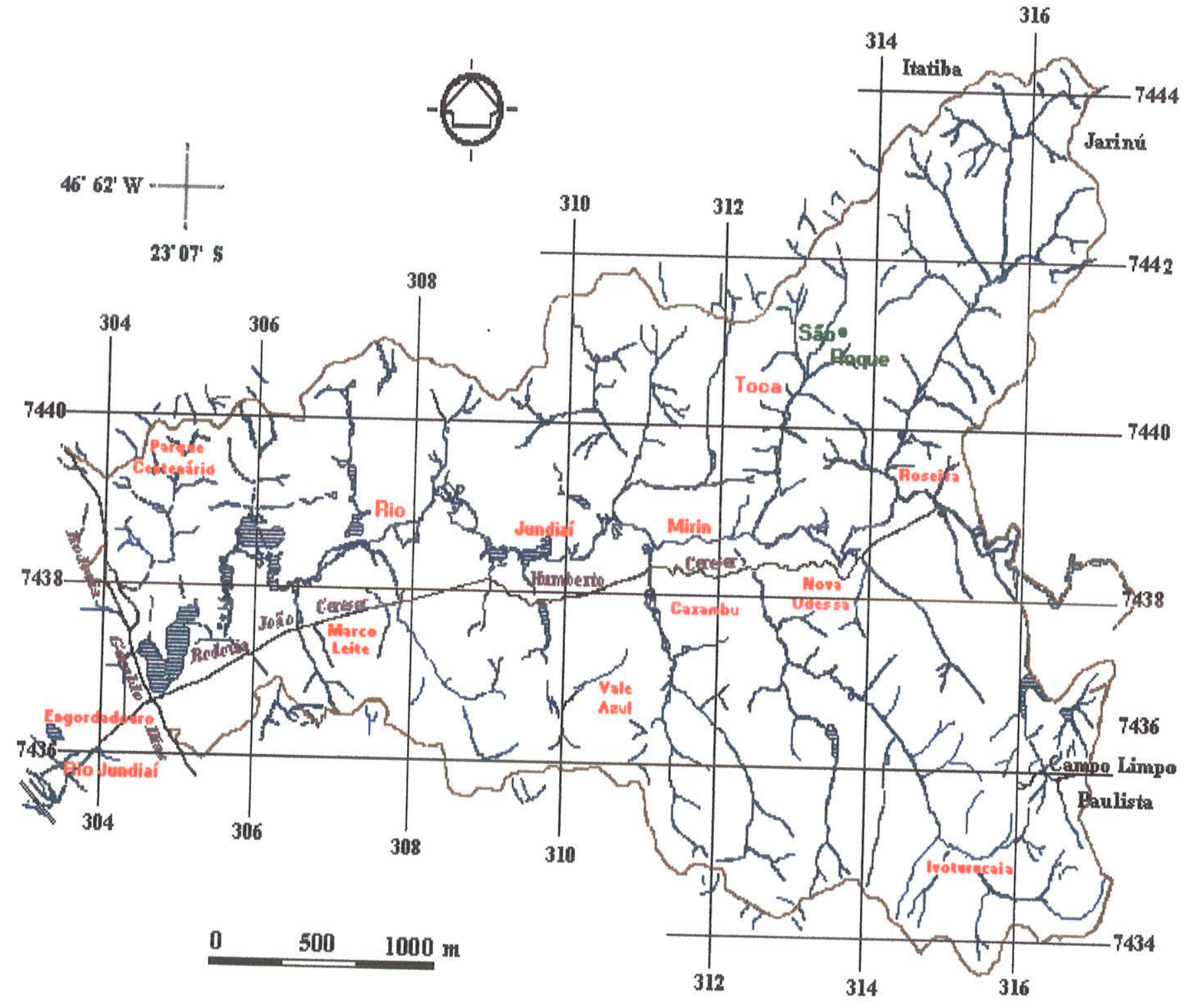

FIGURA 5.3. Bacia Hidrográfica do Rio Jundiaí-Mirim (PREFEITURA DO MUNICÍPIO DE JUNDIAÍ, 1998) 


\section{TRATAMENTO E CARACTERIZAÇÃO DAS AMOSTRAS}

Ao longo das quadras de plantio foram instaladas três estações: a primeira, Estação Experimental I $\left[\mathrm{EE}_{(\mathrm{l})}\right]$, corresponde ao ponto de referência (branco) denominada Bambuzeiro - área isenta de tratamento químico; a segunda, Estação Experimental II $\left[\mathrm{EE}_{(\mathrm{II})}\right]$, escolhida pelo plantio de pêssego em Cambissolo, e a última, Estação Experimental III [ $\left.\mathrm{EE}_{(\mathrm{III})}\right]$, escolhida pelo plantio de pêssego em Latossolo.

Em locais escolhidos estrategicamente, foram abertas trincheiras $(120 \times 120 \times 150 \mathrm{~cm})$ para coleta de material deformado $\mathrm{e}$ indeformado. Para realização de ensaios laboratoriais, coletou-se também material representativo de modo a abranger todos os horizontes de interesse. O material foi quarteado, transferido para sacos plásticos, rotulados e armazenados para transporte.

Nas Estações Experimentais, baseando-se na profundidade média das raízes de pessegueiros, foram instalados lisímetros de sucção, com 50 e $100 \mathrm{~cm}$ de profundidade. Próximo às Estações encontram-se os poços de monitoração [PM(I) $\mathrm{e}$ $\left.\mathrm{PM}_{(\mathrm{III})}\right]$, além de poço cacimba, também na Estação III [ $\left.\mathrm{PC}_{(\mathrm{III})}\right]$, possibilitando coletas periódicas de água do aqǘfero. As perfurações dos poços $\mathrm{PM}_{(\mathrm{II})}$ e $\mathrm{PC}_{(\mathrm{III})}$ permitiram o levantamento do perfis pedológicos de 2200 e $1200 \mathrm{~cm}$, respectivamente. Para os experimentos, efetuou-se coleta de material inconsolidado (solos), representativo de horizontes característicos de cada Estação Experimental. A amostragem de águas de superfície corresponderam aos três reservatórios $\left(R_{1}, R_{2} e\right.$ $\mathrm{R}_{3}$ ), a nascente São Roque (SR) e ao córrego da Toca (CT).

$\mathrm{Na}$ figura 6.1 encontram-se imagens fotográficas da área de estudo,a saber: a. cultura de pêssego em Latossolo; b. Estação Experimental II; c. procedimento de amostragem de água da zona não-saturada e d. poço de monitoração (II). A representação cartográfica da área de estudo em escala 1:1000, com mapa de localização dos pontos amostrados do sítio São Roque encontra-se na figura 6.2 . 

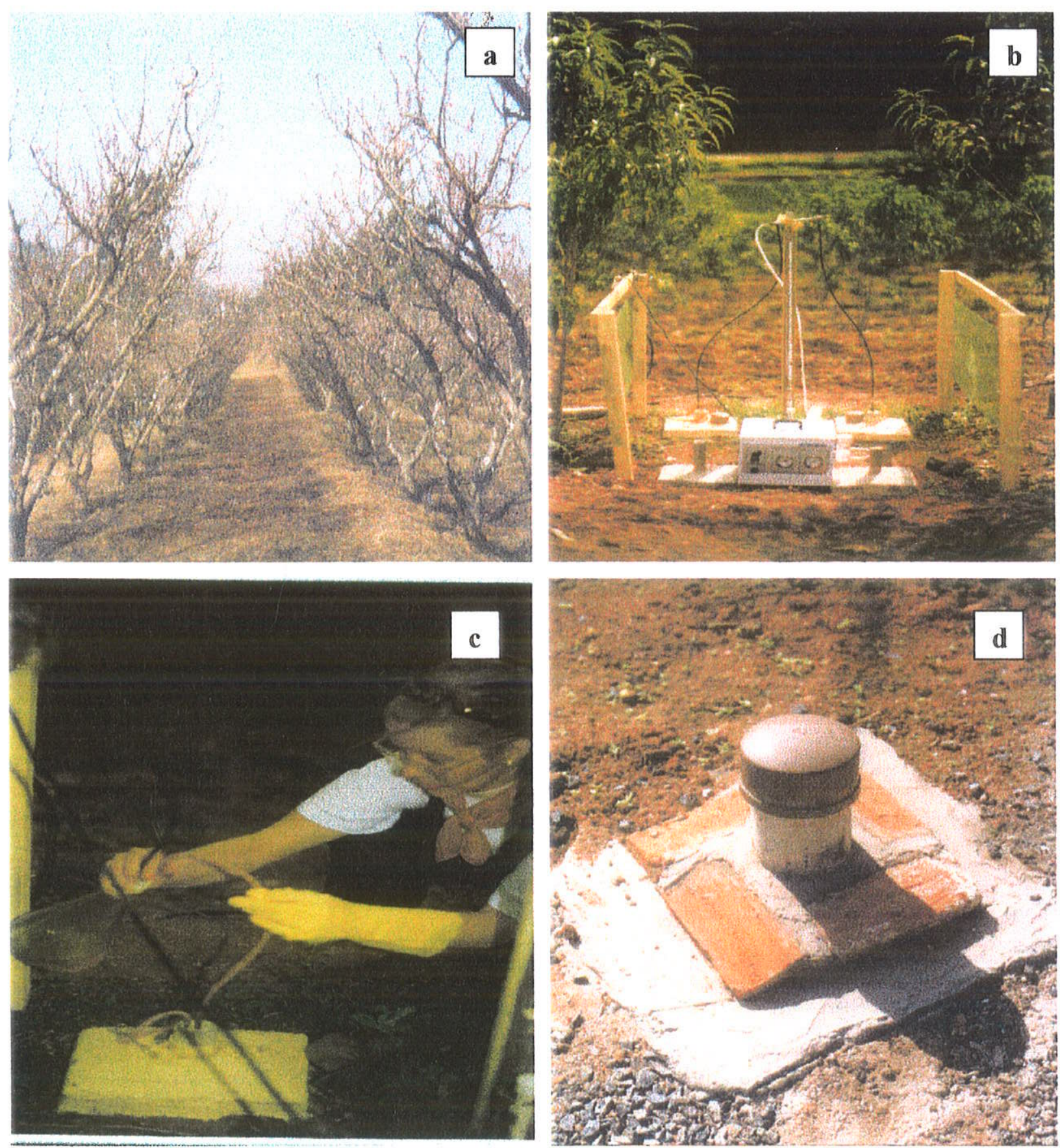

FIGURA 6.1. Vista geral da área de estudo: a.cultura de pêssego em Latossolo; b.

Estação Experimental II; c. procedimento de amostragem de água da zona nãosaturada; d. poço de monitoração (II) 


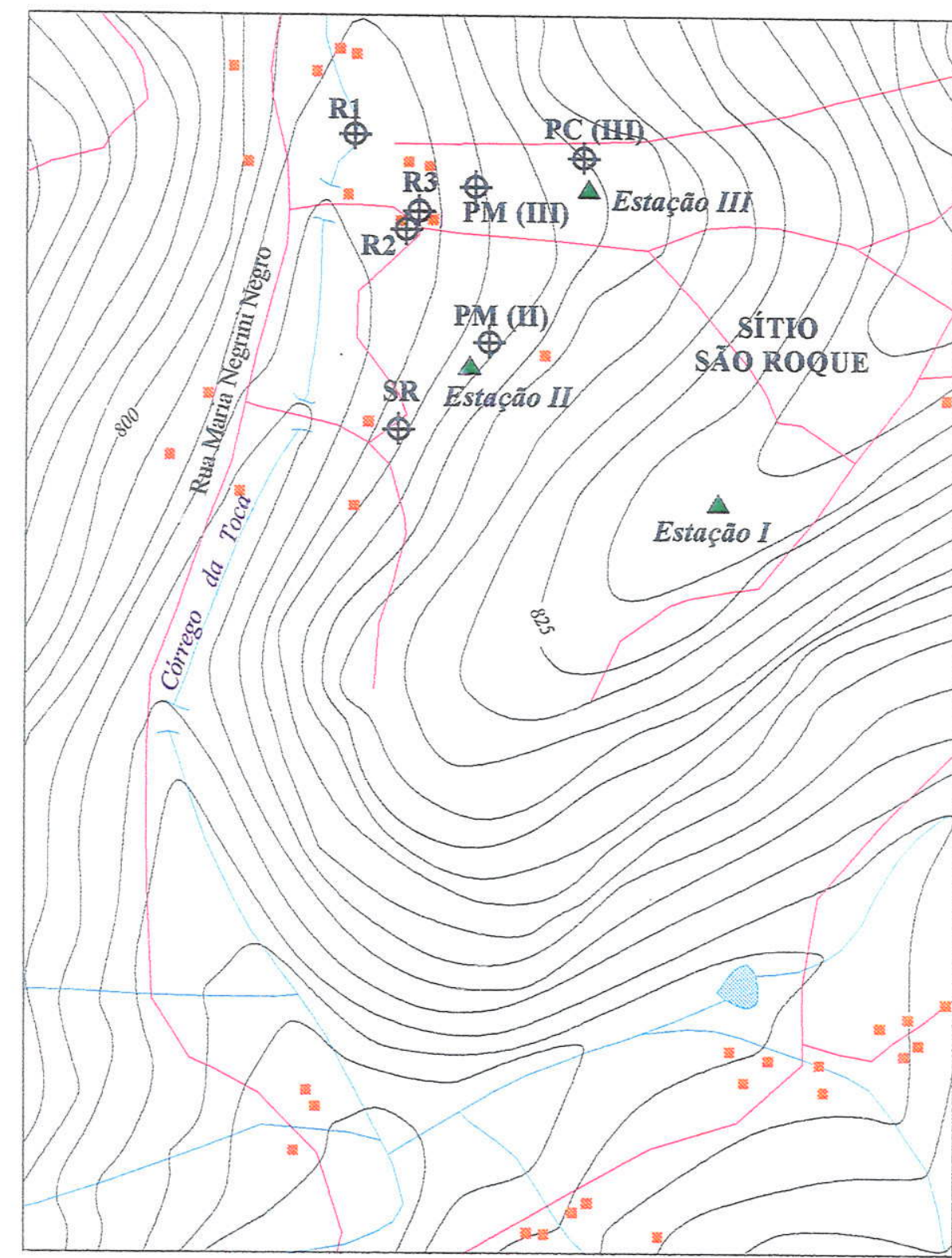

Base: Folhas Topográficas Bairro Mato Dentro e Jundiaí - IGC Escala 1:10 000, 1979. Valquiria Campos

\section{Mapa de Localização dos Pontos Amostrados Sítio São Roque 1998 \\ ESCALA 1:5000

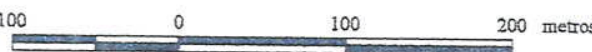 \\ $\Delta \quad$ Estação experimental

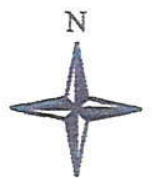 \\ † Ponto de amostragem das águas \\ SR Identificação dos pontos de amostragem das águas \\ Estrada \\ : Edificações \\ Curso d'água \\ - Lago, represa. \\ 歪 Curvas de nível equidistância de 5 metros}

Localização do Município de Jundiaí no Estado de São Paulo e da Área de Estudo no Municipio

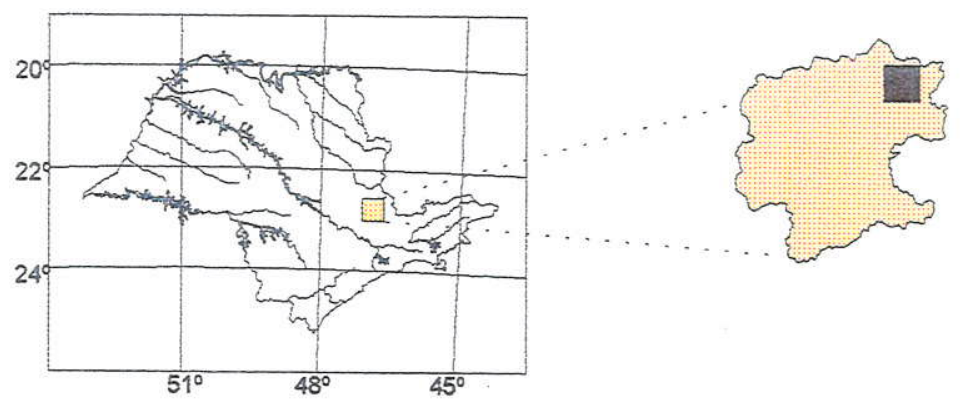

FIGURA 6.2. Representação cartográfica dos pontos amostrados na área de estudo. 


\section{ROCHAS E SOLOS}

As rochas e materiais intemperizados foram coletados através da abertura de trincheiras e durante a execução dos poços de monitoração e poço cacimba. As diversas etapas no tratamento dessas amostras são apresentadas em formato de fluxograma (figura 6.3).

Tratamento de amostras de rochas e solos
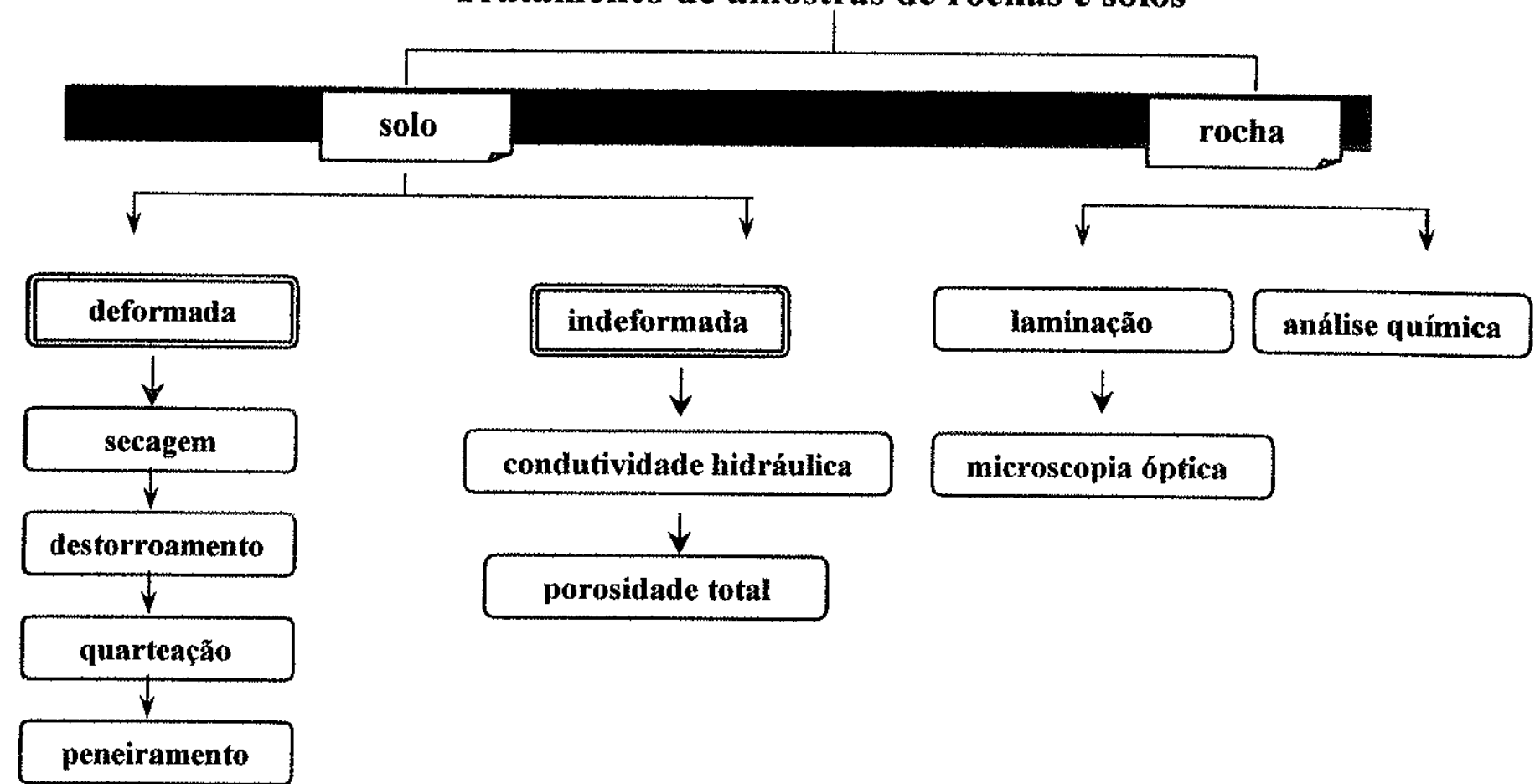

porosidade tota

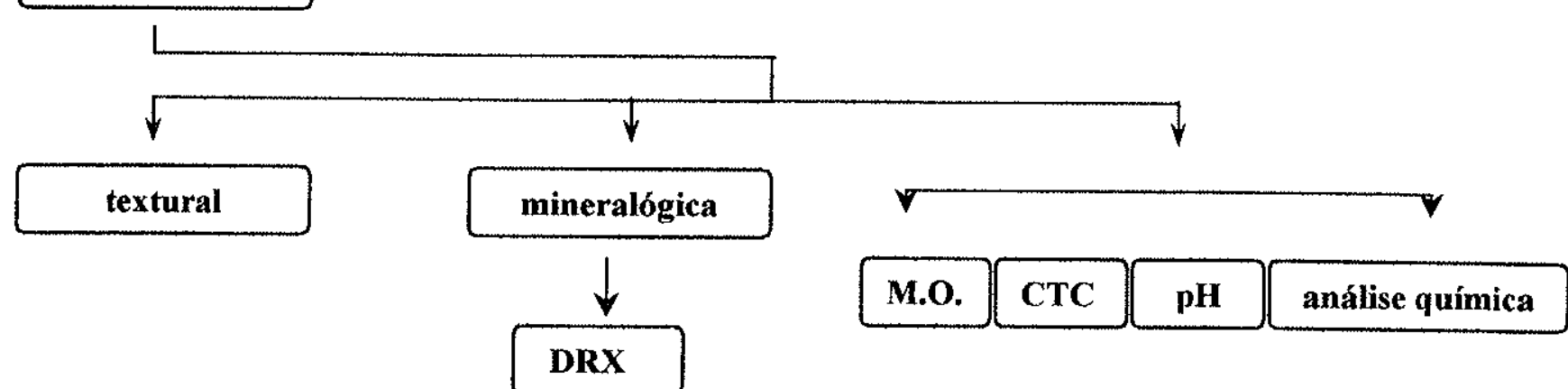

FIGURA 6.3 - Fluxograma de fases no tratamento de amostras de rochas e solos 


\section{ROCHAS}

O material rochoso foi encaminhado para caracterização litológica da área de estudo, no tocante a petrografia, composição mineralógica e química (elementos maiores e traço).

\section{ANÁLISE PETROGRÁFICA E MINERALÓGICA}

Dos materiais rochosos amostrados nas Estações Experimentais foram confeccionadas lâminas, analisadas por microscopia petrográfica.

$\mathrm{O}$ material da Estação I exibe textura granoblástica deformada em que o quartzo apresenta-se como único mineral resistente presente, tratando-se de quartzito.

$\mathrm{Na}$ Estação II o material exibe textura granoblástica pavimentosa poligonal e blastomilonítica, ressaltada pela presença de "augen" onde o feldspato apresenta alteração intempérica adiantada. A rocha classifica-se como mica-ortoclásio quartzito (transição para gnaisse).

As amostras da Estação III apresentam textura lepidoblástica deformada com quartzo na forma de lentículas, muscovita fina e biotita grossa em bandas dobradas. O material (mica xisto) classifica-se especificamente como quartzo-muscovitabiotita xisto.

$\mathrm{Na}$ área de estudo encontram-se, portanto, rochas metamórficas, notadamente quartzosas, principalmente constituídas por quartzitos e mica xisto.

Os difratogramas de raios $\mathrm{X}$ das rochas em estudo, apresentaram somente picos caracterísitcos de quartzo. Isto pode ser evidenciado também, mediante análise química das rochas. 


\section{ANÁLISE QUÍMICA}

As análises químicas das rochas quanto aos elementos maiores e traços de interesse encontram-se na tabela 6.1 e 6.2 .

TABELA 6.1 - Composição química de material rochoso procedente das Estações Experimentais I, II e III

\begin{tabular}{cccc}
\hline Óxido & Estação I & Estação II & Estacão III \\
\cline { 2 - 4 } & teor $(\%)$ & teor $(\%)$ & teor $(\%)$ \\
\hline $\mathrm{SiO}_{2}$ & 94,20 & 95,40 & 69,91 \\
$\mathrm{Al}_{2} \mathrm{O}_{3}$ & 0,37 & 0,22 & 16,32 \\
$\mathrm{Fe}_{2} \mathrm{O}_{3}$ & 0,08 & 0,01 & 3,10 \\
$\mathrm{MnO}$ & $n . d$. & $n . d$. & 0,03 \\
$\mathrm{MgO}$ & 0,01 & 0,01 & 0,99 \\
$\mathbf{C a O}$ & $n . d$. & $n . d$. & $n . d$. \\
$\mathrm{Na}_{2} \mathrm{O}$ & $n . d$. & $n . d$. & 0,08 \\
$\mathrm{~K}_{2} \mathrm{O}$ & 4,10 & 3,80 & 5,00 \\
$\mathrm{TiO}_{2}$ & 0,01 & 0,01 & 0,41 \\
$\mathbf{P}_{2} \mathrm{O}_{5}$ & 0,02 & 0,01 & 0,02 \\
$\mathbf{P F}$ & 0,25 & 0,38 & 3,22 \\
\hline
\end{tabular}

Nota: $n$.d., não detectado (limite de deteç̧ão para $\mathrm{Mn}$, $\mathrm{Ca}$ e $\mathrm{Na}<0,005 \%$ )

Estes dados validam a descrição anterior, principalmente quanto a presença de quartzo e ortoclásio. 
TABELA 6.2 - Resultados analíticos de arsênio e metais pesados de material rochoso procedente das Estações Experimentais I, II e III

\begin{tabular}{|c|c|c|c|c|c|}
\hline rocha & As & $\mathrm{Cr}$ & $\mathrm{Cu}$ & $\mathbf{P b}$ & $\mathrm{Hg}$ \\
\hline Estação I & n.d. & 17,54 & 0,98 & 2,76 & n.d. \\
\hline Estação II & n.d. & 19,93 & 12,92 & 13,53 & n.d. \\
\hline Estação III & n.d. & 39,00 & 15,65 & 12,73 & n.d. \\
\hline
\end{tabular}




\section{SOLOS}

\section{ANÁLISE TEXTURAL}

A abertura de trincheiras $(120 \times 120 \times 150 \mathrm{~cm})$ possibilitou a descrição táctilvisual do solo e coleta de amostras para caracterização e utilização nos ensaios. A coloração, segundo a carta de solos MUNSELL (1994), auxiliou a descrição morfológica do perfil do solo.

O critério coloração possibilitou a demarcação visual de quatro horizontes na Estação I, dois na Estação II e um na Estação III, como mostra a tabela 6.3.

TABELA 6.3 - Classificação visual de níveis estudados em cada Estação Experimental, a profundidade é dada $\mathrm{em} \mathrm{cm}$

\begin{tabular}{ccccccccc}
\hline estação & nível & $\mathbf{c m}$ & nível & $\mathbf{c m}$ & nível & $\mathbf{c m}$ & nível & cm \\
\hline EE I & A & $0-30$ & B & $30-60$ & $\mathbb{B}_{1}$ & $60-90$ & $\mathbf{B}_{2}$ & $90-150$ \\
EE II & A & $0-90$ & B & $90-150$ & - & - & - & - \\
EE III & A & $0-150$ & - & - & - & - & - & - \\
\hline
\end{tabular}

A execução do poço cacimba, na Estação Experimental III, permitiu a coleta de material e descrição do perfil de 12 metros até a rocha inalterada. Na Estação Experimental II perfurou-se um poço de monitoração com 22 metros utilizando perfuratriz.

Na figura 6.4 encontram-se imagens fotográficas do poço cacimba, durante a coleta de amostras e a perfuratriz utilizada na execução do poço de monitoração II. 

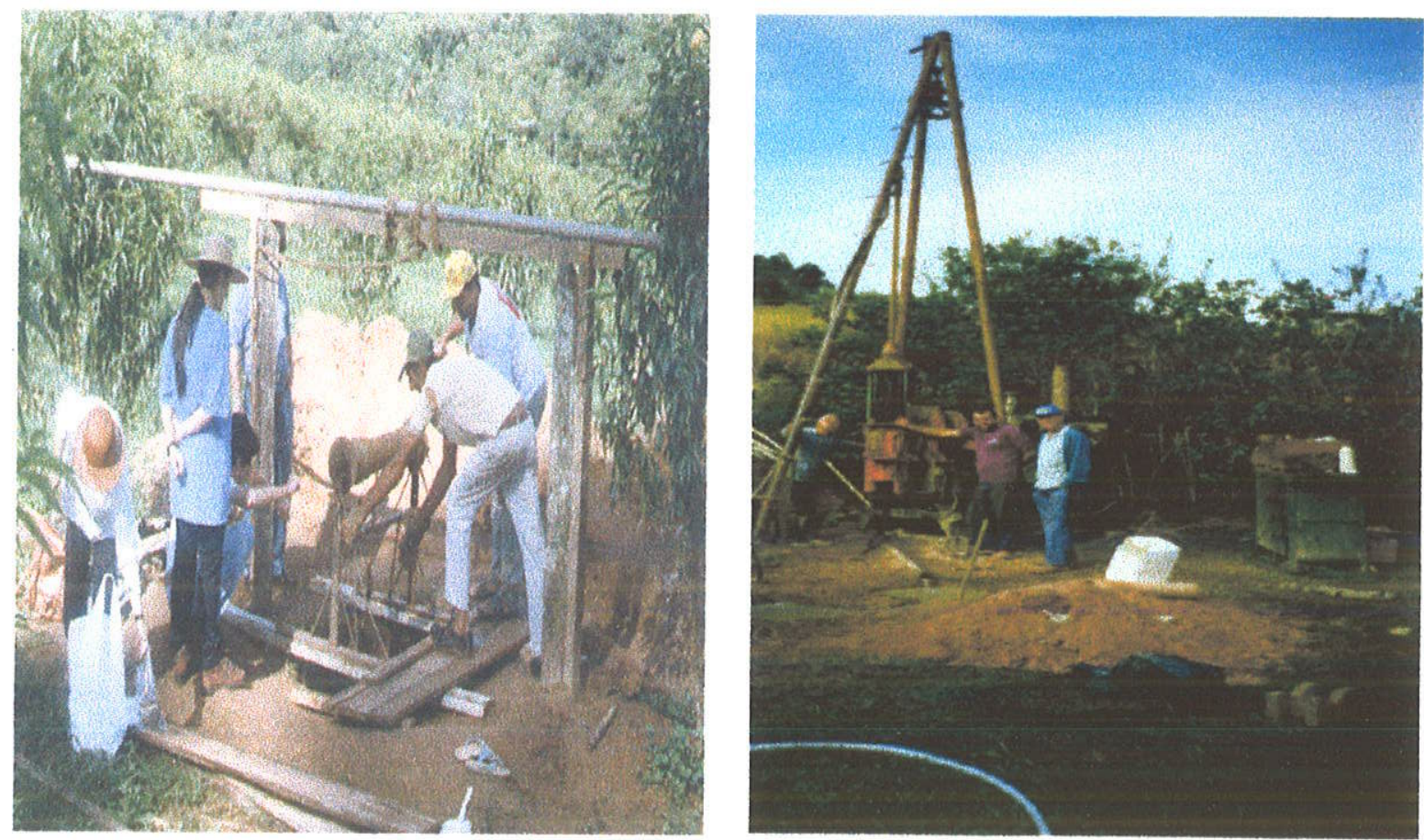

FIGURA 6.4. Imagens fotográficas do poço cacimba, durante a coleta de amostras e a perfuratriz utilizada na execução do poço de monitoração II.

As frações granulométricas foram analisadas pelos métodos de peneiramento e pipetagem Nas tabelas $6.4,6.5$ e 6.6 são apresentados os resultados das análises granulométricas, texturais e critérios de coloração em diferentes profundidades. Acompanhando as tabelas têm-se os respectivos diagramas de porcentagem da fração granulométrica em função da profundidade (figuras 6.5, 6.6 e 6.7). 
TABELA 6.4 - Resultados de análises granulométrica, textural e coloração dos horizontes da Estação I, com profundidade de até $150 \mathrm{~cm}$

\begin{tabular}{|c|c|c|c|c|c|c|}
\hline \multirow[b]{2}{*}{ amostra } & \multirow{2}{*}{$\begin{array}{l}\text { profundidade } \\
\qquad(\mathrm{cm})\end{array}$} & \multicolumn{3}{|c|}{ fração granulométrica (\%) } & \multirow[b]{2}{*}{ textura } & \multirow[b]{2}{*}{ coloração } \\
\hline & & argila & silte & areia & & \\
\hline $\mathbf{I}_{(\mathrm{T} 1)}$ & $0-30$ & 25,43 & 11,76 & 62,81 & $\begin{array}{c}\text { Franco argilo } \\
\text { arenoso }\end{array}$ & 7.5 YR $4 / 3$ \\
\hline $\mathbf{I}_{(\mathbf{T} 2)}$ & $30-60$ & 26,41 & 10,47 & 63,12 & $\begin{array}{l}\text { Franco argilo } \\
\text { arenoso }\end{array}$ & 7.5 YR $5 / 4$ \\
\hline $\mathbf{I}_{(\mathbf{T} 3)}$ & $60-90$ & 20,16 & 18,33 & 61,51 & Franco & 5YR 5/4 \\
\hline $\mathbf{I}_{(\mathbf{T} 4)}$ & $90-120$ & 11,25 & 14,48 & 74,27 & Franco arenoso & 5 YR $6 / 3$ \\
\hline $\mathbf{I}_{(\mathbf{T} 5)}$ & $120-150$ & 12,95 & 16,44 & 70,61 & Franco arenoso & 5 YR $6 / 3$ \\
\hline
\end{tabular}

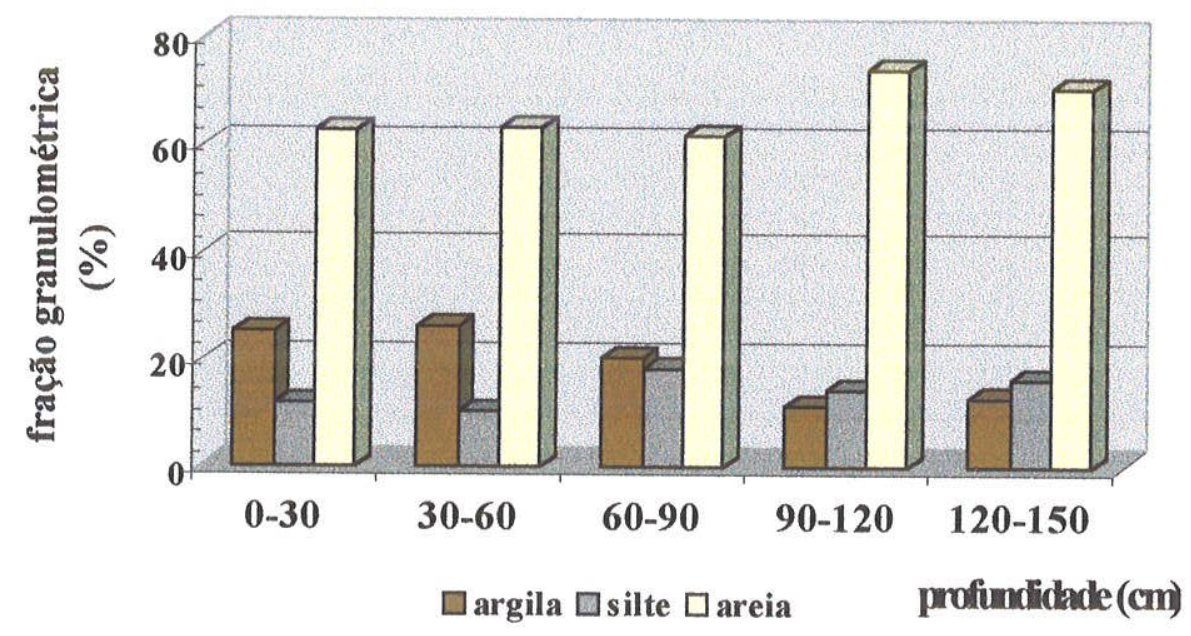

FIGURA 6.5. Resultados de análises granulométricas da Estação I, com profundidade de até $150 \mathrm{~cm}$ 
TABELA 6.5 - Resultados de análises granulométrica, textural e coloração dos horizontes da Estação II, com profundidade de até $2200 \mathrm{~cm}$

\begin{tabular}{|c|c|c|c|c|c|c|}
\hline \multirow[b]{2}{*}{ amostra } & \multirow{2}{*}{$\begin{array}{c}\text { profundidade } \\
(\mathrm{cm})\end{array}$} & \multicolumn{3}{|c|}{ fração granulométrica (\%) } & \multirow[b]{2}{*}{ textura } & \multirow[b]{2}{*}{ coloração } \\
\hline & & argila & silte & areia & & \\
\hline $\mathbf{I}_{(\mathbf{T} 1)}$ & $0-30$ & 19,81 & 11,29 & 68,90 & $\begin{array}{c}\text { Franco argilo } \\
\text { arenoso }\end{array}$ & $7.5 \mathrm{YR} 5 / 3$ \\
\hline $\mathbf{I I}_{(\mathbf{T} 2)}$ & $30-60$ & 20,30 & 9,73 & 69,97 & $\begin{array}{c}\text { Franco argilo } \\
\text { arenoso }\end{array}$ & 7.5 YR $5 / 3$ \\
\hline $\mathbf{I I}_{(\mathrm{T} 3)}$ & $60-90$ & 21,13 & 11,42 & 67,45 & $\begin{array}{l}\text { Franco argilo } \\
\text { arenoso }\end{array}$ & 7.5 YR $5 / 3$ \\
\hline $\mathbf{I}_{(\mathbf{T} 4)}$ & $90-120$ & 16,09 & 11,57 & 72,34 & Franco arenoso & 5YR 5/6 \\
\hline $\mathbf{I I}_{(\mathbf{T 5})}$ & $120-150$ & 12,09 & 14,57 & 73,34 & Franco arenoso & 5 YR $5 / 6$ \\
\hline $\mathbf{I}_{(\mathbf{P 1})}$ & 300 & 10,87 & 6,99 & 82,14 & Areia franca & 5 YR $6 / 8$ \\
\hline $\mathbf{I I}_{(\mathbf{P} 2)}$ & 400 & 8,97 & 7,73 & 83,30 & Areia franca & $7.5 \mathrm{YR} 7 / 6$ \\
\hline $\mathbf{I}_{(\mathbf{P} 3)}$ & 800 & 7,40 & 8,77 & 83,83 & Areia franca & 10YR $7 / 6$ \\
\hline $\mathbf{I I}_{(\mathbf{P 4})}$ & 1200 & 5,70 & 5,85 & 88,45 & Areia franca & 10YR $8 / 4$ \\
\hline $\mathbf{I I}_{(\mathbf{P 5})}$ & 1600 & 6,02 & 4,98 & 89,00 & Areia & 10 YR $8 / 4$ \\
\hline $\mathbf{I I}_{(\mathbf{P 6})}$ & 2200 & 4,62 & 7,92 & 87,46 & Areia franca & $2.5 Y 7 / 4$ \\
\hline
\end{tabular}

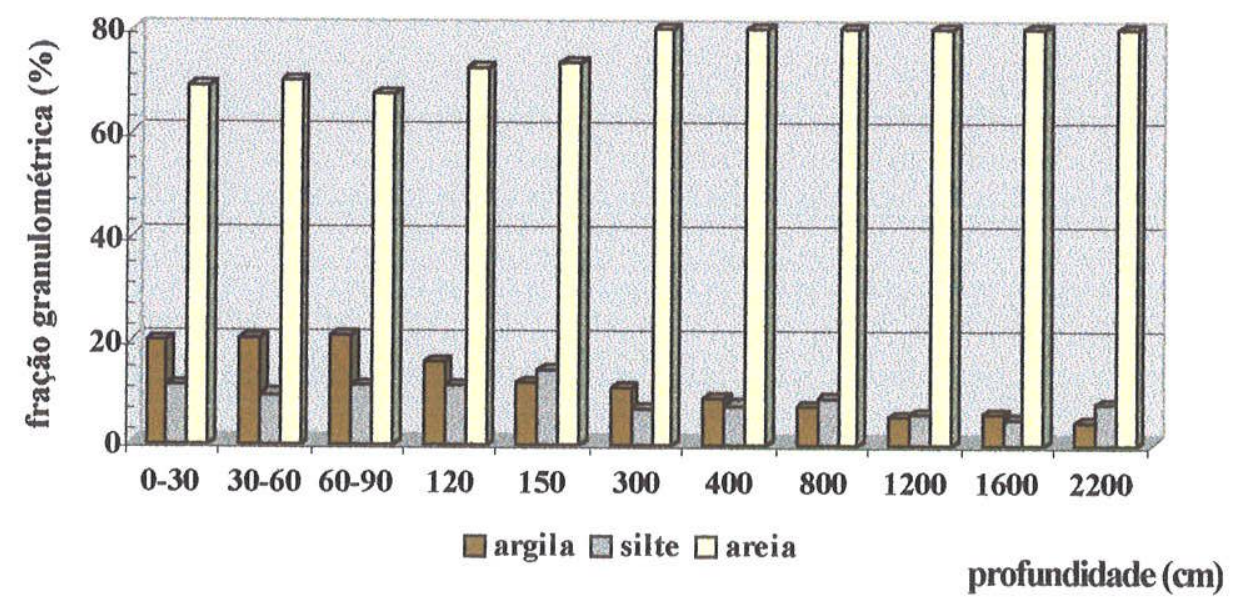

FIGURA 6.6. Resultados de análises granulométricas da Estação II, com profundidade de até $2200 \mathrm{~cm}$ 
TABELA 6.6 - Resultados de análises granulométrica, textural e coloração dos horizontes da Estação III, com profundidade de até $1200 \mathrm{~cm}$

\begin{tabular}{|c|c|c|c|c|c|c|}
\hline \multirow[b]{2}{*}{ amostra } & \multirow{2}{*}{$\begin{array}{l}\text { profundidade } \\
\text { (cm) }\end{array}$} & \multicolumn{3}{|c|}{ fração granulométrica (\%) } & \multirow[b]{2}{*}{ textura } & \multirow[b]{2}{*}{ coloração } \\
\hline & & argila & silte & areia & & \\
\hline $\mathbf{H I}_{(\mathrm{T} 1)}$ & $0-30$ & 22,84 & 15,74 & 61,42 & $\begin{array}{c}\text { Franco argilo } \\
\text { arenoso }\end{array}$ & $7.5 \mathrm{YR} 5 / 4$ \\
\hline $\mathbf{I I I}_{(\mathrm{T} 2)}$ & $30-60$ & 26,40 & 10,70 & 62,90 & $\begin{array}{c}\text { Franco argilo } \\
\text { arenoso }\end{array}$ & 7.5 YR $5 / 4$ \\
\hline $\mathbf{I I}_{(\mathrm{r} 3)}$ & $60-90$ & 25,09 & 22,81 & 52,10 & Franco & 7.5 YR $5 / 4$ \\
\hline $\mathbf{I T}_{(\mathrm{T} 4)}$ & $90-120$ & 26,58 & 19,24 & 54,18 & Franco & 7.5 YR $5 / 4$ \\
\hline $\mathbf{I I}_{(\mathbf{T s})}$ & $120-150$ & 32,46 & 8,13 & 59,20 & $\begin{array}{c}\text { Franco argilo } \\
\text { arenoso }\end{array}$ & $7.5 Y R 5 / 4$ \\
\hline $\mathbf{I I I}_{(\mathbf{P I})}$ & 300 & 35,38 & 7,79 & 56,83 & $\begin{array}{c}\text { Franco argilo } \\
\text { arenoso }\end{array}$ & 7.5 YR $5 / 6$ \\
\hline $\mathbf{I I I}_{(\mathbf{P} 2)}$ & 400 & 34,83 & 8,16 & 57,01 & $\begin{array}{c}\text { Franco argilo } \\
\text { arenoso }\end{array}$ & $7.5 \times \mathrm{YR} 6 / 6$ \\
\hline $\operatorname{III}_{(\mathbf{P 3})}$ & 500 & 37,68 & 6,43 & 55,89 & Argila arenosa & $7.5 Y \mathrm{YR} 6 / 6$ \\
\hline III $_{(\mathbf{P 4})}$ & 600 & 34,09 & 7,23 & 58,68 & $\begin{array}{c}\text { Franco argilo } \\
\text { arenoso }\end{array}$ & 7.5 YR $7 / 6$ \\
\hline $\mathbf{I I}_{(\mathbf{P S})}$ & 700 & 32,12 & 10,59 & 57,29 & $\begin{array}{l}\text { Franco argilo } \\
\text { arenoso }\end{array}$ & 2.5 YR $7 / 2$ \\
\hline III $($ (P6) & 800 & 27,07 & 12,78 & 60,15 & $\begin{array}{c}\text { Franco argilo } \\
\text { arenoso }\end{array}$ & $7.5 Y R 7 / 2$ \\
\hline $\mathbf{I I}_{(\mathbf{P 7})}$ & 1000 & 6,96 & 16,02 & 77,02 & Franco arenoso & $2.5 Y R 7 / 1$ \\
\hline $\mathbf{I I I}_{(\mathbf{P 8})}$ & 1200 & 7,14 & 15,46 & 77,40 & Franco arenoso & $7.5 Y R \quad 8 / 2$ \\
\hline
\end{tabular}




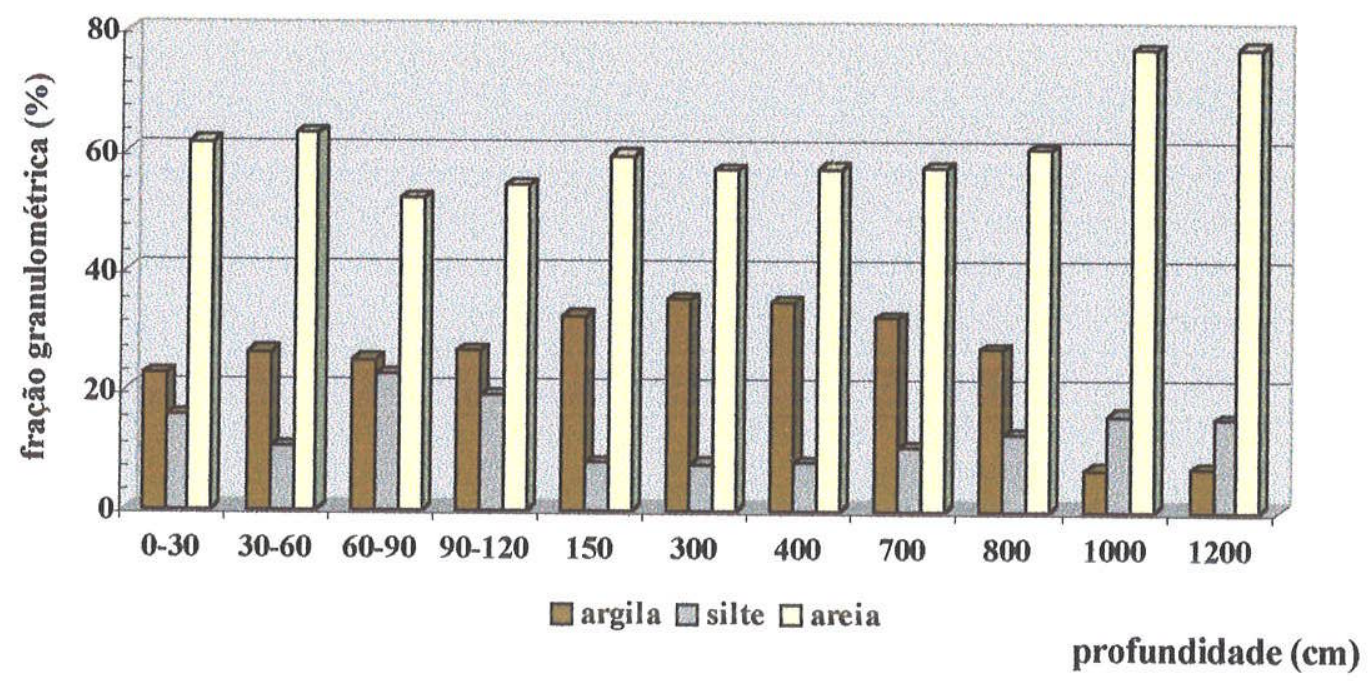

FIGURA 6.7. Resultados de análises granulométricas da Estação III, com profundidade de até $1200 \mathrm{~cm}$

Os resultados das análises granulométricas indicam predomínio acentuado da fração areia em todas as Estações. Na Estação Experimental III tem-se conteúdo de argila superior às Estações I e II, o que imprime características diferentes aos solos.

$\mathrm{Na}$ figura 6.8, as frações granulométricas foram projetadas em Diagrama de Classificação Textural de Solos segundo modelo adotado no Instituto Agronômico de Campinas (OLIVEIRA et al. 1992). 


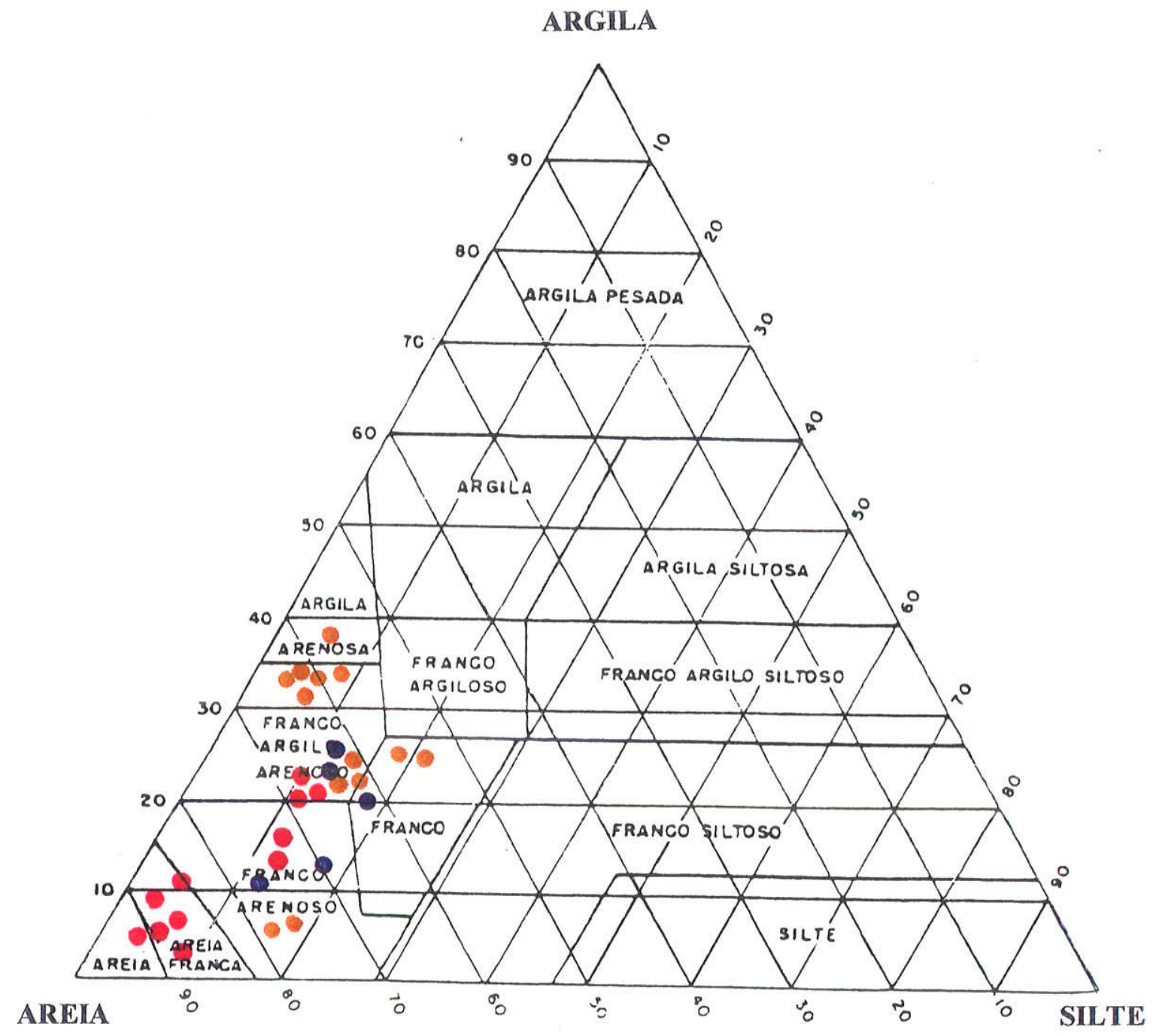

Legenda:

- Estação Experimental II

Estação Experimental III

Estação Experimental IIII
Areia $(0,02-2 \mathrm{~mm})$

Silte $(0,002-0,02 \mathrm{~mm})$

Argila $(<0,002 \mathrm{~mm})$

FIGURA 6.8. Diagrama de Classificação Textural de Solos segundo modelo adotado no Instituto Agronômico de Campinas, com pontos amostrados nas Estações Experimentais 


\section{ANÁLISE MINERALÓGICA}

Os materiais amostrados foram caracterizados mineralogicamente através de difratometria de raios $X$, cujos resultados são apresentados nas tabelas 6.7, 6.8 e 6.9.

TABELA 6.7 - Composição mineralógica da Estação I com amostragem em diferentes níveis de profundidade

\begin{tabular}{ccc}
\hline Estação I & profundidade (cm) & Composição Mineralógica \\
\hline $0-30$ & caulinita, quartzo e goethita \\
$30-60$ & caulinita e quartzo \\
$60-90$ & caulinita, quartzo e goethita \\
$90-120$ & caulinita, quartzo, goethita e muscovita \\
$120-150$ & caulinita, quartzo, goethita e muscovita \\
\hline
\end{tabular}

TABELA 6.8 - Composição mineralógica da Estação II com amostragem em diferentes níveis de profundidade

\begin{tabular}{ccc}
\hline Estação II & profundidade (cm) & Composição Mineralógica \\
\hline $0-30$ & caulinita, quartzo, goethita e hematita \\
$30-60$ & caulinita, quartzo, goethita e hematita \\
$60-90$ & caulinita, quartzo, goethita e hematita \\
$90-120$ & caulinita, quartzo goethita e muscovita \\
$120-150$ & caulinita, quartzo, goethita e muscovita \\
\hline
\end{tabular}

TABELA 6.9 - Composição mineralógica da Estação III com amostragem em diferentes níveis de profundidade

\begin{tabular}{ccc}
\hline Estação III & profundidade (cm) & Composição Mineralógica \\
\hline $0-30$ & caulinita, quartzo e goethita \\
$30-60$ & caulinita, quartzo e goethita \\
$60-90$ & caulinita, quartzo e goethita \\
$90-120$ & caulinita, quartzo e goethita \\
$120-150$ & caulinita, quartzo, muscovita, biotita \\
\hline
\end{tabular}


Os difratogramas apresentaram mineralogia simples e uniforme com reflexões basais de argilomineral do tipo 1:1, quartzo e óxidos e hidróxidos de ferro. $\mathrm{Na}$ Estação Experimental III, o solo apresenta-se bastante uniforme, constituído praticamente por material inconsolidado proveniente do topo da encosta. Nas Estações I e II observa-se, ao longo dos horizontes, presença de fragmentos de rocha fresca ainda em processo de alteração. 


\section{CONDUTIVIDADE HIDRÁULICA}

Os ensaios de condutividade hidráulica $(\mathrm{K})$ foram efetuados no campo (método de carga variável) e em laboratório (método carga constante).

Em campo, na zona não-saturada, realizou-se ensaio de infiltração com carga variável, para determinação de condutividade hidráulica. Foram efetuados furos de sondagem com profundidade de $150 \mathrm{~cm}$, com perfurações executadas com trado helicoidal de $21 / 2$ ". Este experimento consiste no preenchimento com água no furo de sondagem onde é estabelecido uma coluna d'água inicial. A injeção de água é interrompida, acompanhando, no decorrer do tempo, o rebaixamento do nível d'água. Os valores obtidos de tempo e rebaixamento foram tratados segundo método de cálculo de condutividade hidráulica (GILG \& GAVARD apud ASSOCIAÇÃO BRASILEIRA DE GEOLOGIA DE ENGENHARIA, 1981). Na tabela 6.10 têm-se os valores obtidos de ensaios de condutividade hidráulica com carga variável.

TABELA 6.10 - Resultados do ensaio por condutividade hidráulica com carga variável

\begin{tabular}{cccc}
\hline Estação & trecho ensaiado $\mathbf{( c m )}$ & textura & K $\left(\mathbf{c m . \mathbf { s } ^ { - 1 } )}\right.$ \\
\hline I & 150 & Argilo-arenoso a arenoso & $2,13.10^{-2}$ \\
II & 150 & Argilo-arenoso a arenoso & $3,47.10^{-2}$ \\
III & 150 & Argilo-arenoso & $7,66.10^{-3}$ \\
\hline
\end{tabular}

Para determinação da condutividade hidráulica em laboratório, as amostras indeformadas foram retiradas em duas profundidades: 0 a $25 \mathrm{~cm}$ e 25 a $50 \mathrm{~cm}$. Na Estação Experimental I, a amostragem foi efetuada até $35 \mathrm{~cm}$ por tratar-se de solo pouco desenvolvido, dificultando a coleta com os cilindros de Uhland. A profundidade para amostragem de até $50 \mathrm{~cm}$ foi estabelecida, tomando por base a extensão em que o solo é preparado para as culturas. 
Os dados de condutividade hidráulica saturada $\left(\mathrm{K}_{\mathrm{s}}\right)$, em diferentes profundidades, são apresentados na tabela 6.11 .

TABELA 6.11 - Resultados de análises, porosidade total $(\eta)$ e condutividade hidráulica saturada $\left(\mathbf{K}_{\mathbf{s}}\right)$

\begin{tabular}{cccc}
\hline estação & profundidade & $\eta(\%)$ & $\mathbf{K}_{\mathbf{s}}\left(\mathbf{c m} . \mathbf{s}^{\mathbf{- 1}}\right)$ \\
\hline I & $05-12$ & 40 & $5,28.10^{-3}$ \\
I & $27-34$ & 44 & $4,26.10^{-3}$ \\
II & $15-22$ & 43 & $1,7.10^{-3}$ \\
II & $45-52$ & 40 & $2,39.10^{-3}$ \\
III & $05-12$ & 50 & $1,66.10^{-3}$ \\
III & $40-47$ & 45 & $1,52.10^{-3}$ \\
\hline
\end{tabular}

As medidas de condutividade hidráulica saturada em amostras indeformadas apresentam variações, quando comparadas àquelas realizadas em campo. Os resultados de condutividade hidráulica indicam que a permeabilidade do solo pode ser considerada de moderada a alta. O predomínio de baixos valores de condutividade hidráulica na Estação Experimental III deve-se a ausência de fragmentos quartzosos e maior teor de argila, conforme resultados granulométricos apresentados. 


\section{CAPACIDADE DE TROCA CATIÔNICA E MATÉRIA ORGÂNICA}

Para melhor compreensão das propriedades dos solos, associados ao meio não-saturado, foi determinada a capacidade de troca catiônica (CTC) que evidencia a facilidade do solo em reter e trocar íons. A troca catiônica corresponde ao processo reversível onde os cátions ficam retidos na superficie de uma fase sólida, podendo ser substituídos por cátions pertencentes a uma fase líquida ou, até mesmo, uma outra fase sólida. Os íons envolvidos na troca ligam-se à estrutura do mineral eletrostaticamente ou por covalência. A quantidade de íons adsorvidos é proporcional à área das partículas tendendo, desta forma, a aumentar as substâncias com elevada superfície específica, como os minerais na fração argila.

Foram efetuadas também determinações de matéria orgânica (M.O.) que corresponde à mistura complexa de compostos de origem biológica em diferentes níveis de oxidação e degradação. Desses compostos, os mais degradados, oxidados e mais estáveis são as substâncias húmicas. Elas são constituídas, essencialmente, da mistura heterogênea de moléculas altamente polimerizadas. A capacidade de ácidos húmicos de fixar íons metálicos é maior que a de muitos argilominerais, formando complexos organometálicos (BEVERIDGE \& PICKERING, 1980).

Os resultados encontram-se na tabela 6.12 e para melhor compreensão, os valores são apresentados ainda como diagramas de colunas nas figuras 6.9 e 6.10 . 
TABELA 6.12 - Valores de capacidade de troca catiônica (CTC) e de matéria orgânica (M.O.) nos solos das Estações Experimentais.

\begin{tabular}{rcc}
\hline Amostra & CTC (meq.100 $\left.\mathbf{g}^{-\mathbf{1}}\right)$ & M.O. (\%) \\
\hline $\mathbf{I}_{\mathbf{A}}$ & 147,63 & 4,40 \\
$\mathbf{I}_{\mathbf{B}}$ & 72,45 & 1,70 \\
$\mathbf{I}_{\mathbf{B 1}}$ & 31,90 & 0,70 \\
$\mathbf{I}_{\mathbf{B} \mathbf{2}}$ & 21,82 & 0,60 \\
$\mathbf{I}_{\mathbf{A}}$ & 166,41 & 2,80 \\
$\mathbf{I}_{\mathbf{B}}$ & 61,34 & 1,00 \\
$\mathbf{I I}_{\mathbf{A}}$ & 92,11 & 2,30 \\
\hline
\end{tabular}

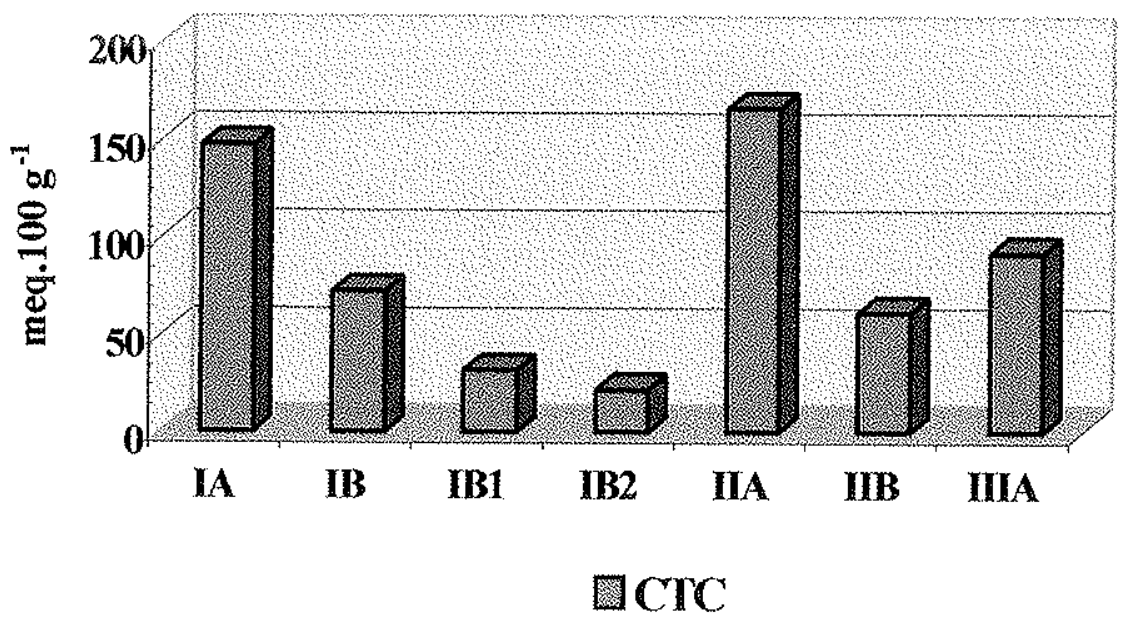

FIGURA 6.9. Resultados de capacidade de troca cationnica (CTC)em horizontes correspondentes a cada Estação Experimental 


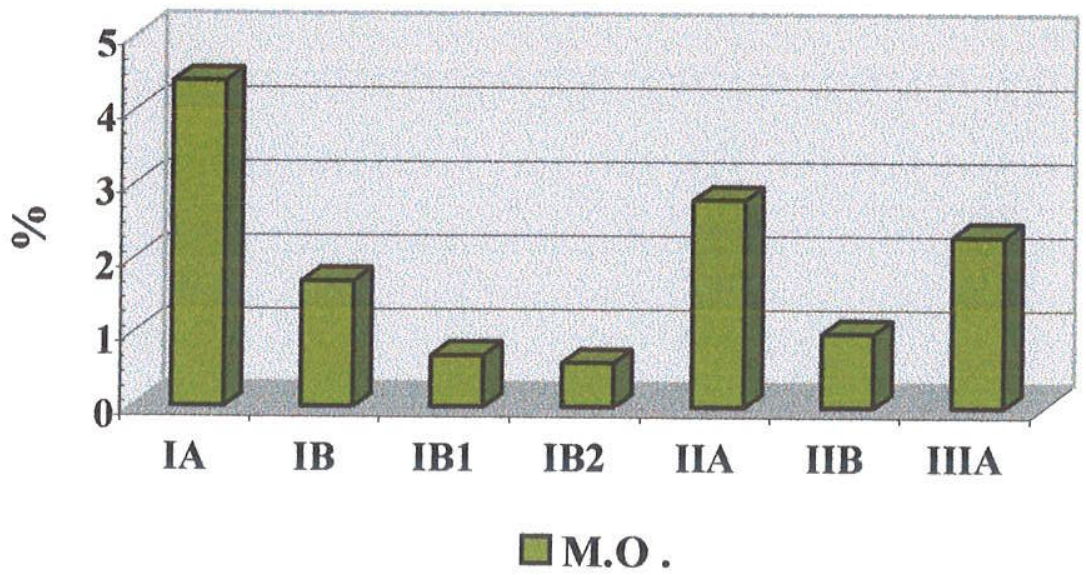

FIGURA 6.10. Resultados de matéria orgânica (M.O.) em horizontes correspondentes a cada Estação Experimental

Observa-se maior concentração de matéria orgânica na porção superficial dos solos, evidenciando estreita correlação entre a capacidade de troca catiônica e o teor de matéria orgânica. 


\section{pH}

Os valores de $\mathrm{pH}$ dos solos foram determinados em água e solução molar de cloreto de potássio, segundo metodologia indicada pela EMPRESA BRASILEIRA DE PESQUISA AGROPECUÁRIA - EMBRAPA (1997), com modificações.

Em béqueres de polietileno rotulados como $A$ e $B$, transferiu-se massa de solo, peneirado em malha $2 \mathrm{~mm}$, correspondente ao volume de $10 \mathrm{~mL}$. Em A, adiciona-se $25 \mathrm{~mL}$ de água destilada previamente fervida e em $\mathrm{B}$, o mesmo volume de solução $\mathrm{KCl} 1 \mathrm{M}$. As misturas foram agitadas por 15 minutos e, após este período, permaneceram em repouso por 30 minutos. A temperatura foi mantida a 25 ${ }^{\circ} \mathrm{C}$ e posteriormente a decantação efetuaram-se leituras dos $\mathrm{pH}$ (tabela 6.13).

TABELA 6.13 - pH de solo nos horizontes dos perfis estudados: $\mathrm{pH}_{\mathrm{H} 2 \mathrm{O}}$ refere-se a leitura em meio aquoso e $\mathrm{pH}_{\mathrm{KCl}}$ em solução potássica e respectivos $\Delta \mathrm{pH}\left(\mathrm{pH}_{\mathrm{H} 2 \mathrm{O}}\right.$ $\left.\mathrm{pH}_{\mathrm{KCl}}\right)$

\begin{tabular}{llll}
\hline amostra & $\mathbf{p H}$ & $\mathbf{p H}$ & \\
\hline $\mathbf{I}_{\mathbf{A C l}}$ & 3,72 & $\Delta \mathbf{p H}$ \\
$\mathbf{I}_{\mathbf{B}}$ & 5,31 & 4,04 & $+1,59$ \\
$\mathbf{I}_{\mathbf{B 1}}$ & 4,54 & 4,13 & $+0,50$ \\
$\mathbf{I}_{\mathbf{B 2}}$ & 5,82 & 3,90 & $+1,69$ \\
$\mathbf{I}_{\mathbf{A}}$ & 4,83 & 5,33 & $+0,93$ \\
$\mathbf{I}_{\mathbf{B}}$ & 5,72 & 4,00 & $+0,39$ \\
$\mathbf{I I}_{\mathbf{A}}$ & 5,65 & 5,21 & $+1,65$ \\
\hline
\end{tabular}

Os valores de $\Delta \mathrm{pH}$ permitem concluir que os solos estudados apresentam partículas coloidais carregadas positivamente, já esperado para solos de natureza ácida. 


\section{ANÁLISE QUÍMICA}

As amostras de solos das estações foram analisadas quimicamente e os resultados dos óxidos encontram-se na tabela 6.14 .

TABELA 6.14 - Composição química de material inconsolidado procedente das

Estações Experimentais I, II e III, segundo demarcação visual em horizontes com teores expressos em (\%)

\begin{tabular}{|c|c|c|c|c|c|c|c|}
\hline \multirow[t]{2}{*}{ Óxido } & IA & IB & IB1 & IB2 & IIA & IIB & IIIA \\
\hline & \multicolumn{7}{|c|}{ teor $(\%)$} \\
\hline $\mathrm{SiO}_{2}$ & 57,10 & 58,26 & 67,41 & 75,13 & 60,39 & 51,29 & 54,79 \\
\hline $\mathbf{A l}_{2} \mathbf{O}_{3}$ & 18,28 & 20,62 & 17,57 & 13,62 & 15,71 & 24,67 & 22,00 \\
\hline $\mathrm{Fe}_{2} \mathrm{O}_{3}$ & 5,60 & 6,55 & 5,61 & 4,20 & 5,02 & 7,82 & 6,54 \\
\hline $\mathrm{MnO}$ & 0,03 & 0,02 & 0,02 & 0,02 & 0,05 & 0,03 & 0,04 \\
\hline MgO & 0,12 & 0,11 & 0,10 & 0,06 & 0,24 & 0,19 & 0,21 \\
\hline $\mathrm{CaO}$ & 0,09 & 0,03 & 0,01 & 0,01 & 1,02 & 0,14 & 0,28 \\
\hline $\mathrm{Na}_{2} \mathrm{O}$ & 0,07 & 0,06 & 0,05 & 0,04 & 0,08 & 0,08 & 0,08 \\
\hline $\mathbf{K}_{2} \mathrm{O}$ & 0,90 & 0,95 & 0,95 & 0,50 & 1,24 & 1,64 & 1,45 \\
\hline $\mathrm{TiO}_{2}$ & 0,81 & 0,86 & 0,77 & 0,64 & 0,82 & 0,95 & 0,98 \\
\hline $\mathbf{P}_{2} \mathbf{O}_{5}$ & 0,09 & 0,07 & 0,05 & 0,03 & 1,80 & 0,33 & 0,51 \\
\hline
\end{tabular}

$\mathrm{O}$ fósforo, na forma de $\mathrm{P}_{2} \mathrm{O}_{5}$, também é relatado quanto a sua forma disponivel. As amostras provenientes das Estações Experimentais foram encaminhadas para análise de fósforo por extração com resina trocadora Amberlite IR-420 (figura 6.11). 


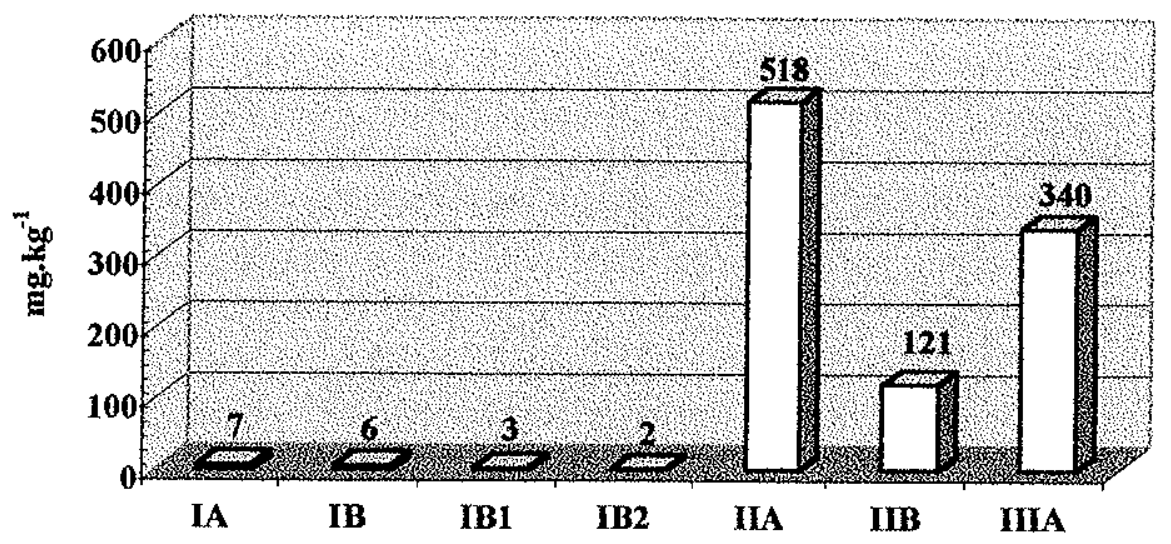

FIGURA 6.11. Diagrama indicando a concentração de fósforo disponível nas Estações Experimentais

A seguir, são apresentados os resultados analíticos de arsênio e metais pesados (cromo, cobre, chumbo e mercúrio), em amostras de solos procedentes das Estações Experimentais (tabelas 6.15, 6.16, 6.17). A variação da concentração de arsênio e metais pesados pode ser visualizada mediante projeções de concentração $\left(\mathrm{mg} \cdot \mathrm{kg}^{-1}\right.$ ) em função da profundidade (cm) (figuras 6.12 a 6.16). Os valores são médias de três determinações. 
TABELA 6.15 - Resultados analíticos de arsênio e metais pesados encontrados no solo da Estação Experimental I, a profundidade é dada em $(\mathrm{cm})$

\begin{tabular}{cccccc}
\hline elemento & $\mathbf{0 - 3 0}$ & $\mathbf{3 0 - 6 0}$ & $\mathbf{6 0 - 9 0}$ & $\mathbf{9 0 - 1 2 0}$ & $\mathbf{1 2 0 - 1 5 0}$ \\
\hline $\mathrm{As}$ & n.d. & n.d. & n.d. & n.d. & n.d. \\
$\mathrm{Cr}$ & 55,2 & 37,4 & 19,5 & 7,8 & 9,7 \\
$\mathrm{Cu}$ & 17,4 & 9,8 & 8,4 & 7,24 & 4,2 \\
$\mathrm{~Pb}$ & 13,9 & 10,7 & 9,3 & 5,7 & 2,7 \\
$\mathrm{Hg}$ & $\mathbf{0 , 2 6}$ & n.d. & n.d. & n.d. & n.d. \\
\hline
\end{tabular}

Nota: $n . d$., não detectado (limites de deteç̧ão: $\mathbf{A s}<0,2 \mathrm{mg} \cdot \mathrm{kg}^{-1}$ e $\mathbf{H g}<0,001 \mu \mathrm{g} \cdot \mathrm{kg}^{-1}$ )

TABELA 6.16 - Resultados analíticos de arsênio e metais pesados encontrados no solo da Estação Experimental II, a profundidade é dada em $(\mathrm{cm})$

\begin{tabular}{cccccc}
\hline elemento & $0-30$ & $30-60$ & $60-90$ & $90-120$ & $120-150$ \\
\hline As & 15,2 & 17,5 & 10,7 & 5,5 & 5,6 \\
Cr & 110,7 & 97,9 & 105,2 & 86,7 & 52,3 \\
Cu & 70,3 & 67,8 & 51,3 & 49,8 & 36,7 \\
Pb & 88,4 & 62,1 & 46,8 & 41,7 & 33,9 \\
Hg & 11,4 & 3,2 & 1,03 & n.d. & n.d. \\
\hline
\end{tabular}

Nota: $n . d$., não detectado (limites de deteç̧ão: $\mathbf{A s}<0,2 \mathrm{mg} \cdot \mathrm{kg}^{-1}$ e $\mathbf{H g}<0,001 \mu \mathrm{g} \cdot \mathrm{kg}^{-1}$ ) 
TABELA 6.17 - Resultados analíticos de arsênio e metais pesados encontrados no solo da Estação Experimetal III, a profundidade é dada em $(\mathrm{cm})$

\begin{tabular}{cccccccccc}
\hline elemento & $0-30$ & $30-60$ & $60-90$ & $90-120$ & $120-150$ & 400 & 600 & 800 & 1200 \\
\hline As & 9,8 & 7,7 & 7,2 & 6,5 & 6,2 & 5,2 & 4,9 & 2,11 & n.d. \\
Cr & 121,7 & 102,3 & 89,6 & 79,2 & 76,3 & 45,2 & 28,7 & 27,2 & 23,7 \\
$\mathrm{Cu}$ & 67,9 & 68,2 & 72,2 & 63,7 & 58,7 & 65,3 & 48,3 & 45,2 & 6,4 \\
$\mathrm{~Pb}$ & 101,2 & 79,2 & 76,4 & 58,4 & 53,2 & 21,3 & 16,8 & 15,4 & 14,7 \\
$\mathrm{Hg}$ & 13,5 & 7,9 & 5,6 & 1,3 & 0,4 & n.d. & n.d. & n.d. & n.d. \\
\hline
\end{tabular}

Nota: $n . d$., não detectado (limites de detecção: As $<0,2 \mathrm{mg} \cdot \mathrm{kg}^{-1}$ e $\mathrm{Hg}<0,001 \mu \mathrm{g} \cdot \mathrm{kg}^{-1}$ ) 

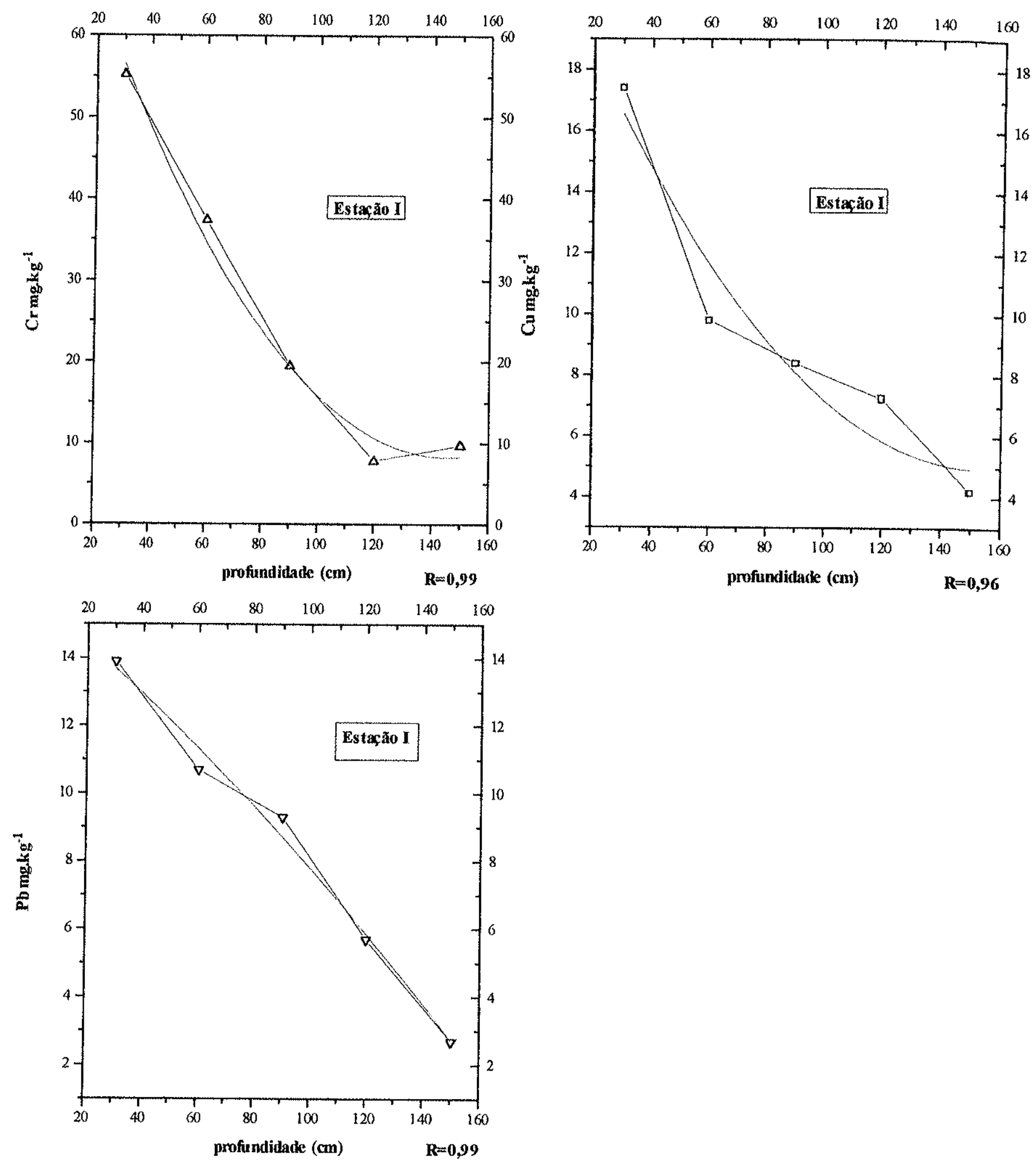

FIGURA 6.12. Gráficos representando a variação da concentração $\left(\mathrm{mg} \cdot \mathrm{kg}^{-1}\right)$ de $\mathrm{Cr}$, $\mathrm{Cu}$ e $\mathrm{Pb}$ em função da profundidade $(\mathrm{cm})$, na Estação Experimental I 

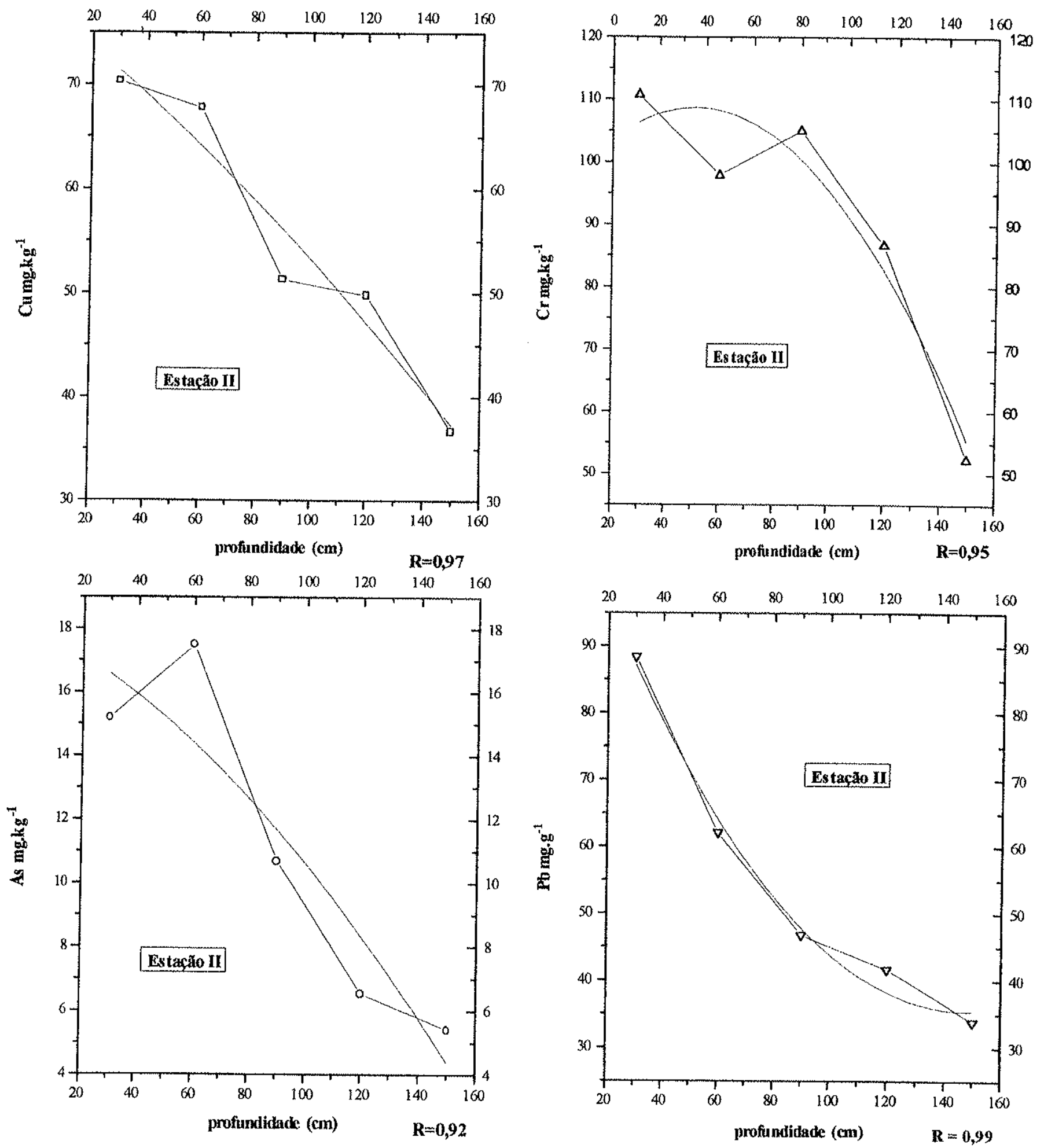

FIGURA 6.13. Gráficos representando a variação da concentração (mg. $\left.\mathrm{kg}^{-1}\right)$ de $\mathrm{As}, \mathrm{Cr}, \mathrm{Cu}$ e $\mathrm{Pb}$ em função da profundidade (cm), na Estação Experimental II 


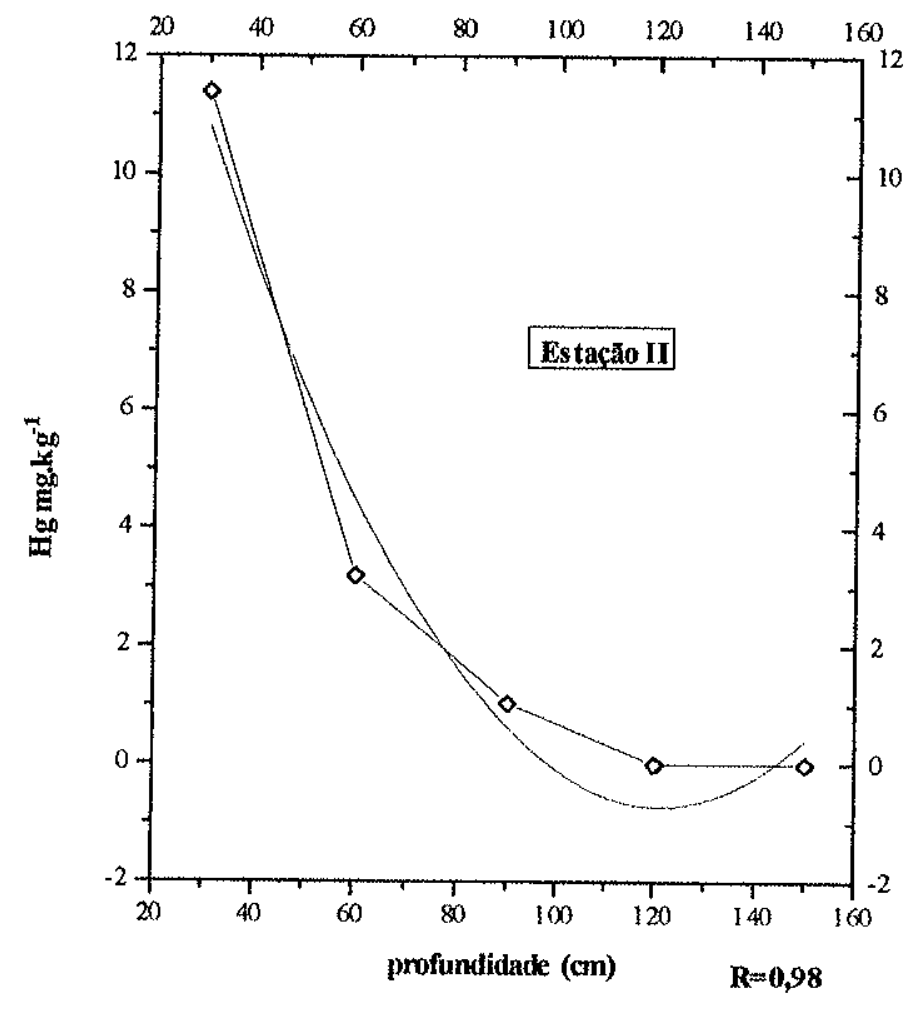

FIGURA 6.14. Gráfico representando a variação da concentração (mg. $\left.\mathrm{kg}^{-1}\right)$ de $\mathrm{Hg}$ em função da profundidade $(\mathrm{cm})$ na Estação Experimental II 

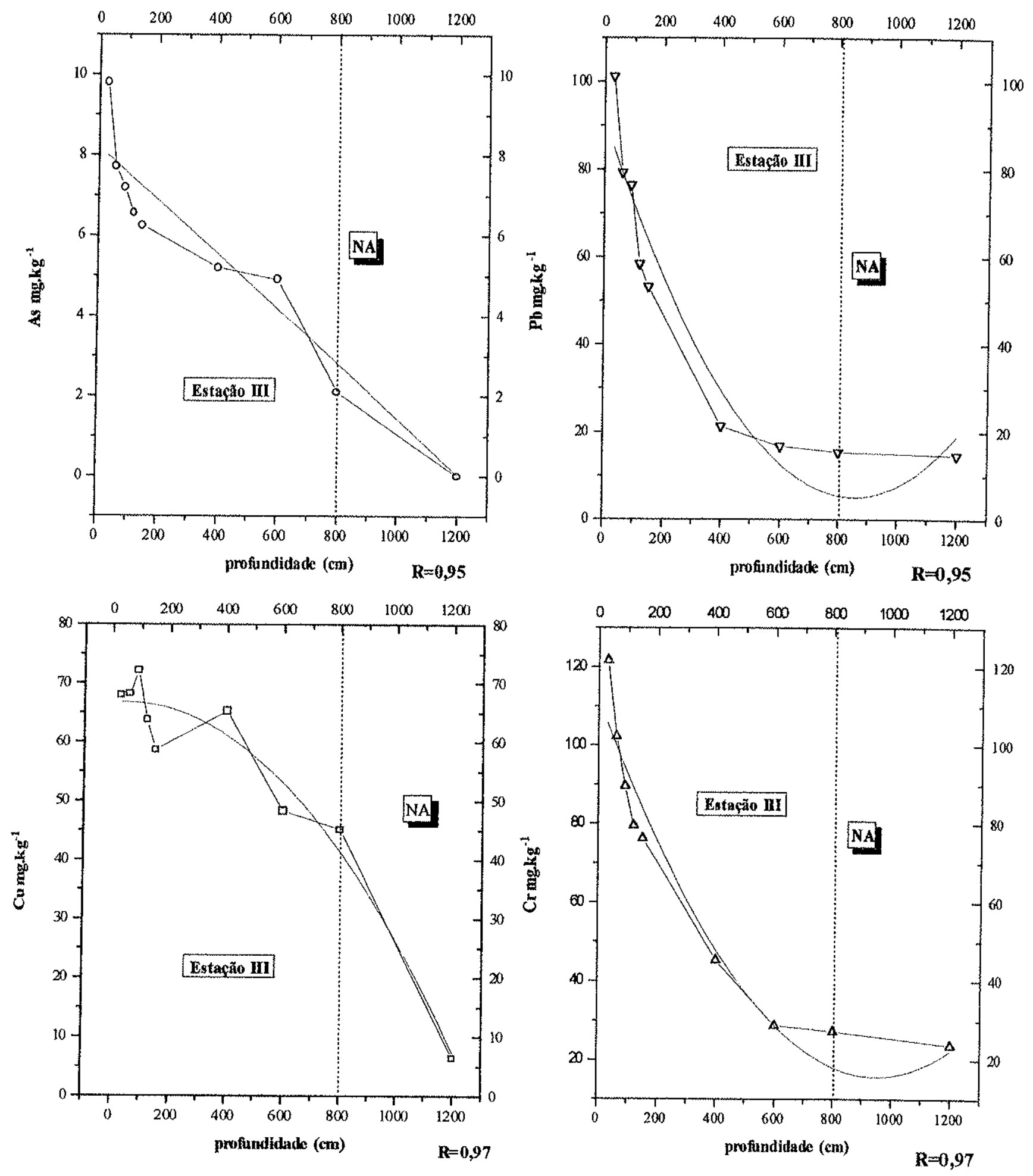

FIGURA 6.15. Gráficos representando a variação da concentração (mg.kg $\left.{ }^{-1}\right)$ de $\mathrm{As}, \mathrm{Cr}, \mathrm{Cu}$ e $\mathrm{Pb}$ em função da profundidade (cm) na Estação Experimental III 


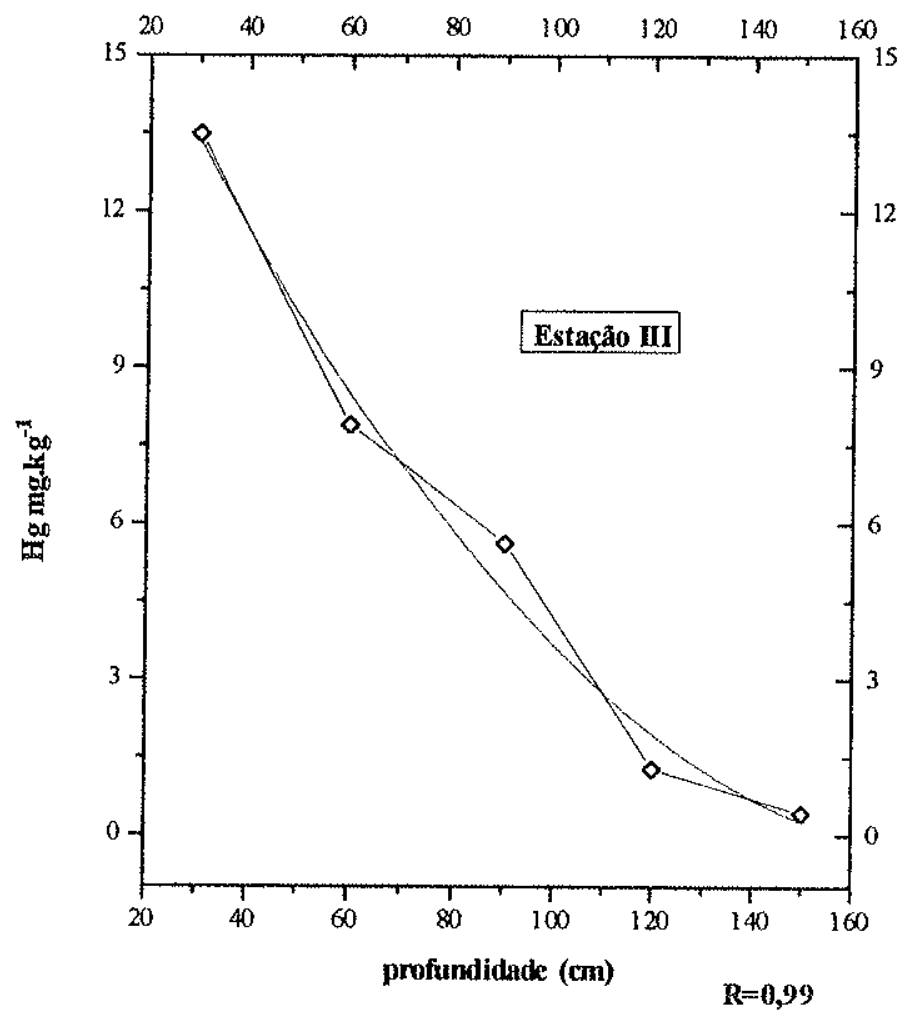

FIGURA 6.16. Gráfico representando a variação da concentração $\left(\mathrm{mg} . \mathrm{kg}^{-1}\right) \mathrm{de} \mathrm{Hg}$ em função da profundidade $(\mathrm{cm})$ na Estação Experimental III

Na Estação Experimental III, observa-se o trajeto migratório dos elementos traço até a zona saturada, entretanto, abaixo do nível freático, o arsênio não foi detectado e o cobre tende a zero. O cromo e chumbo, por sua vez mantiveram-se no perfil. Em todos os casos, os teores são mais significativos para os primeiros centímetros do solo. 


\section{EXTRAÇÕES COM ÁGUA E ÁGUA/GÁS CARBÔNICO}

Para estimar a contribuição dos íons intersticiais associados ao sistema solo/água efetuaram-se extração com água e água saturada com gás carbônico.

Os íons intersticiais e mesmo aqueles fracamente adsorvidos nos constituíntes dos solos foram extraídos com água à temperatura ambiente e com água saturada de $\mathrm{CO}_{2}$ a temperatura ao redor de $70^{\circ} \mathrm{C}$.

As amostras de solos foram tratadas com volume conhecido de água, durante 24 horas em temperatura ambiente. Os resultados das análises químicas dessas extrações são apresentados na tabela 6.18. Para melhor visualização desses resultados, os dados foram projetados em diagrama (figura 6.17).

TABELA 6.18 - Resultados analíticos das soluções, produtos das extrações com $\mathrm{H}_{2} \mathrm{O}$ (mg. $\left.\mathrm{L}^{-1}\right)$

\begin{tabular}{ccccccc}
\hline amostra & $\mathbf{A s}$ & $\mathbf{P b}$ & $\mathbf{C r}$ & $\mathbf{C u}$ & $\mathbf{H g}$ & $\mathbf{P}$ \\
\hline $\mathbf{I}_{\mathbf{A}}$ & $n . d$. & 0,02 & 0,01 & 0,03 & n.d. & n.d. \\
$\mathbf{I}_{\mathbf{B}}$ & $n . d$. & 0,02 & 0,01 & 0,02 & $n . d$. & n.d. \\
$\mathbf{I}_{\mathbf{B} \mathbf{1}}$ & $n . d$. & 0,01 & $n . d$. & 0,01 & n.d. & n.d. \\
$\mathbf{I}_{\mathbf{B} 2}$ & $n . d$. & 0,01 & $n . d$. & 0,01 & n.d. & n.d. \\
$\mathbf{I}_{\mathbf{A}}$ & 0,04 & 0,03 & 0,02 & 0,07 & n.d. & n.d. \\
$\mathbf{I}_{\mathbf{B}}$ & 0,02 & 0,02 & 0,01 & 0,03 & n.d. & n.d. \\
$\mathbf{I I}_{\mathbf{A}}$ & 0,05 & 0,03 & 0,02 & 0,08 & n.d. & n.d.
\end{tabular}

Nota: $n$.d., não detectado (limites de deteç̧ão: $\mathbf{P O}_{4}{ }^{3-}<10 \mathrm{mg} . \mathrm{L}^{-1} ;$ As $<0,03 \mu \mathrm{g} \cdot \mathrm{L}^{-1} ; \mathbf{H g}<$ $0,001 \mu \mathrm{g} \cdot \mathrm{L}^{-1}$ e $\left.\mathbf{C r}<0,5 \mu \mathrm{g} \cdot \mathrm{L}^{-1}\right)$ 


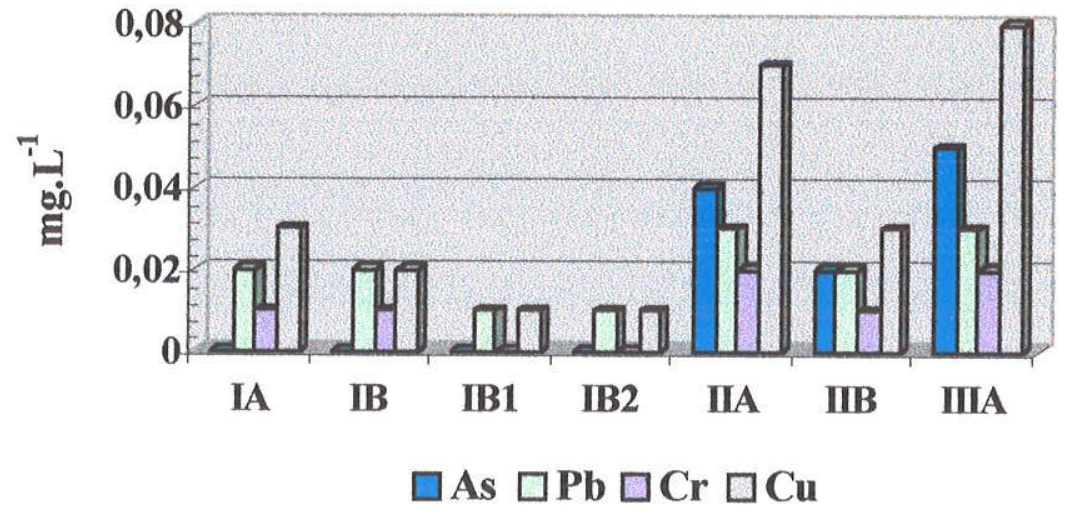

FIGURA 6.17. Resultados analíticos (elementos traço) das soluções finais após extrações com água (mg. $\left.\mathrm{L}^{-1}\right)$

Os ensaios de lixiviação com água saturada de $\mathrm{CO}_{2}\left(70^{\circ} \mathrm{C}\right)$ foram realizados através de extrator do tipo soxhlet. Nestes experimentos tem-se a simulação referente à mobilidade iônica dos solos estudados sujeitos a lixiviação pluvial.

As extrações foram efetuadas em período de 24 horas com leituras iniciais e finais de $\mathrm{pH}$ (tabela 6.19). Os resultados analíticos dos íons extraídos com $\mathrm{H}_{2} \mathrm{O} / \mathrm{CO}_{2}$ são apresentados na tabela 6.20 e figura 6.18 .

TABELA 6.19 - Valores de pH (inicial e final) de soluções resultantes de extrações em soxhlet $\left(\mathrm{H}_{2} \mathrm{O} / \mathrm{CO}_{2}\right)$

\begin{tabular}{lll}
\hline amostra & $\mathbf{p H}_{\mathbf{i}}$ & $\mathbf{p H}_{\mathbf{f}}$ \\
\hline $\mathbf{I}_{\mathbf{A}}$ & 4,82 & 4,05 \\
$\mathbf{I}_{\mathbf{B}}$ & 4,90 & 4,46 \\
$\mathbf{I}_{\mathbf{B 1}}$ & 4,82 & 4,13 \\
$\mathbf{I}_{\mathbf{B} \mathbf{2}}$ & 4,96 & 4,45 \\
$\mathbf{I}_{\mathbf{A}}$ & 5,64 & 4,92 \\
$\mathbf{I I}_{\mathbf{B}}$ & 4,95 & 4,60 \\
$\mathbf{I I I}_{\mathbf{A}}$ & 5,17 & 5,00 \\
\hline
\end{tabular}


TABELA 6.20 - Resultados analíticos (elementos traço e fósforo) das soluções finais após extrações com água e gás carbônico $\left(\mathrm{mg} . \mathrm{L}^{-1}\right)$

\begin{tabular}{ccccccc}
\hline amostra & $\mathbf{A s}$ & $\mathbf{P b}$ & $\mathbf{C r}$ & $\mathbf{C u}$ & $\mathbf{H g}$ & $\mathbf{P}$ \\
\hline $\mathbf{I}_{\mathbf{A}}$ & $n . d$. & 0,02 & 0,01 & 0,05 & $n . d$. & n.d. \\
$\mathbf{I}_{\mathbf{B}}$ & $n . d$. & 0,01 & 0,01 & 0,02 & $n . d$. & n.d. \\
$\mathbf{I}_{\mathbf{B} \mathbf{1}}$ & $n . d$. & 0,01 & 0,01 & 0,02 & n.d. & n.d. \\
$\mathbf{I}_{\mathbf{B} \mathbf{2}}$ & $n . d$. & 0,01 & 0,02 & 0,07 & n.d. & n.d. \\
$\mathbf{I}_{\mathbf{A}}$ & 0,06 & 0,05 & 0,02 & 0,11 & n.d. & n.d. \\
$\mathbf{I}_{\mathbf{B}}$ & 0,04 & 0,03 & 0,02 & 0,08 & n.d. & n.d. \\
$\mathbf{I I}_{\mathbf{A}}$ & 0,07 & 0,05 & 0,03 & 0,12 & n.d. & n.d.
\end{tabular}

Nota: $n$.d., não detectado (limites de deteç̧ão: $\mathbf{P O}_{4}{ }^{3-}<10 \mathrm{mg} . \mathrm{L}^{-1} ; \mathbf{A s}<0,03 \mu \mathrm{g} . \mathrm{L}^{-1} \mathrm{e} \mathbf{H} \mathbf{g}<$ $\left.0,001 \mu \mathrm{g} \cdot \mathrm{L}^{-1}\right)$

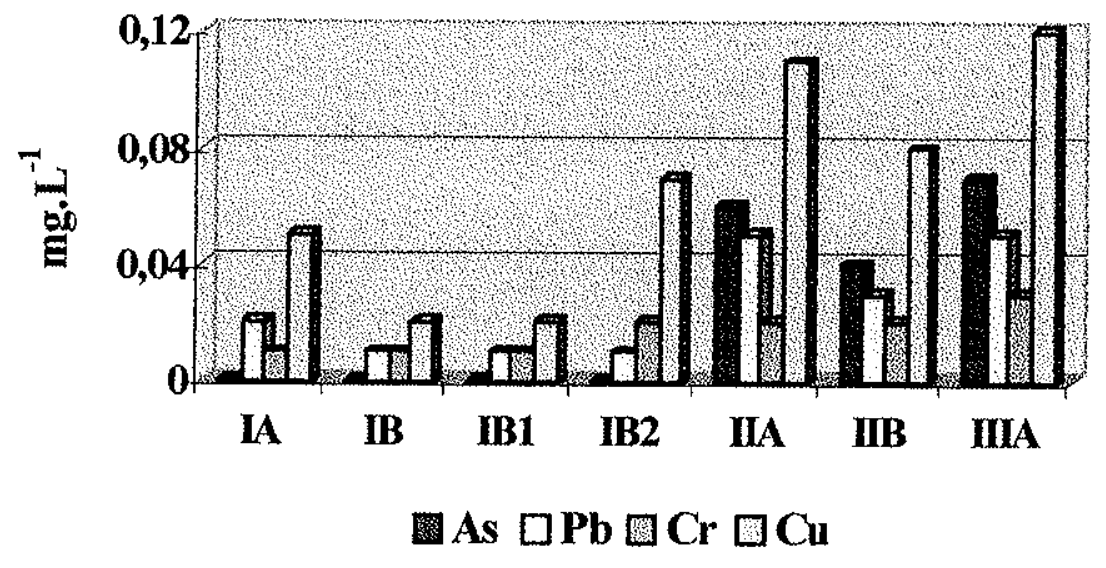

FIGURA 6.18. Resultados analíticos (elementos traço) das soluções finais após extrações com água e gás carbônico (mg. $\mathrm{L}^{-1}$ ) 


\section{ÁGUA}

A amostragem de água da zona não-saturada foi efetuada através de lisimetros de sucção. Os lisímetros foram instalados após perfuração com trado helicoidal de $21 / 2 "$, tendo na porção inferior do tubo PVC (policloreto de vinila) revestimento com pó de sílica (malha 200) para impedir que os poros fossem obstruídos por material argiloso. As paredes laterais, acima da camada de pó de sílica, foram preenchidas com bentonita e material inconsolidado proveniente da perfuração, para impedir a escoamento vertical de solutos.

A amostragem de água da zona saturada foi efetuada utilizando coletor bailer, descartável. Todas as amostras foram filtradas com membrana de acetato de celulose e acondicionadas em garrafas de polietileno. Para análise de cátions e arsênio, adicionou-se solução $0,2 \%$ de $\mathrm{HNO}_{3}$. As amostras para determinação de ânions e como testemunhos foram acondicionadas em ambiente refrigerado a $4{ }^{\circ} \mathrm{C}$.

A coleta de água de chuva foi efetuada através de coletor de deposição total a uma altura de $120 \mathrm{~cm}$ do solo. Este coletor foi mantido coberto, ao abrigo da luz, para minimizar reações mediadas por microorganismos e mudanças fotoquímicas possiveis de ocorrer durante o período de estocagem.

A amostragem de águas superficiais compreende a coleta nos reservatórios $R_{1}, R_{2}$ e $R_{3}$ utilizados na irrigação do solo, assim como a nascente São Roque (SR) e córrego da Toca (CT). As águas foram coletadas com garrafas de polietileno, previamente ambientalizadas com água a ser coletada.

Em campo, na coleta das águas superficiais e subterrâneas, foram efetuadas leituras de nível d'água, $\mathrm{pH}$, Eh, condutividade elétrica especifica (CE) e alcalinidade. Na figura 6.19 tem-se fluxograma indicando locais, parâmetros medidos, tratamento de amostras e destino analítico. 


\section{Tratamento de Água}

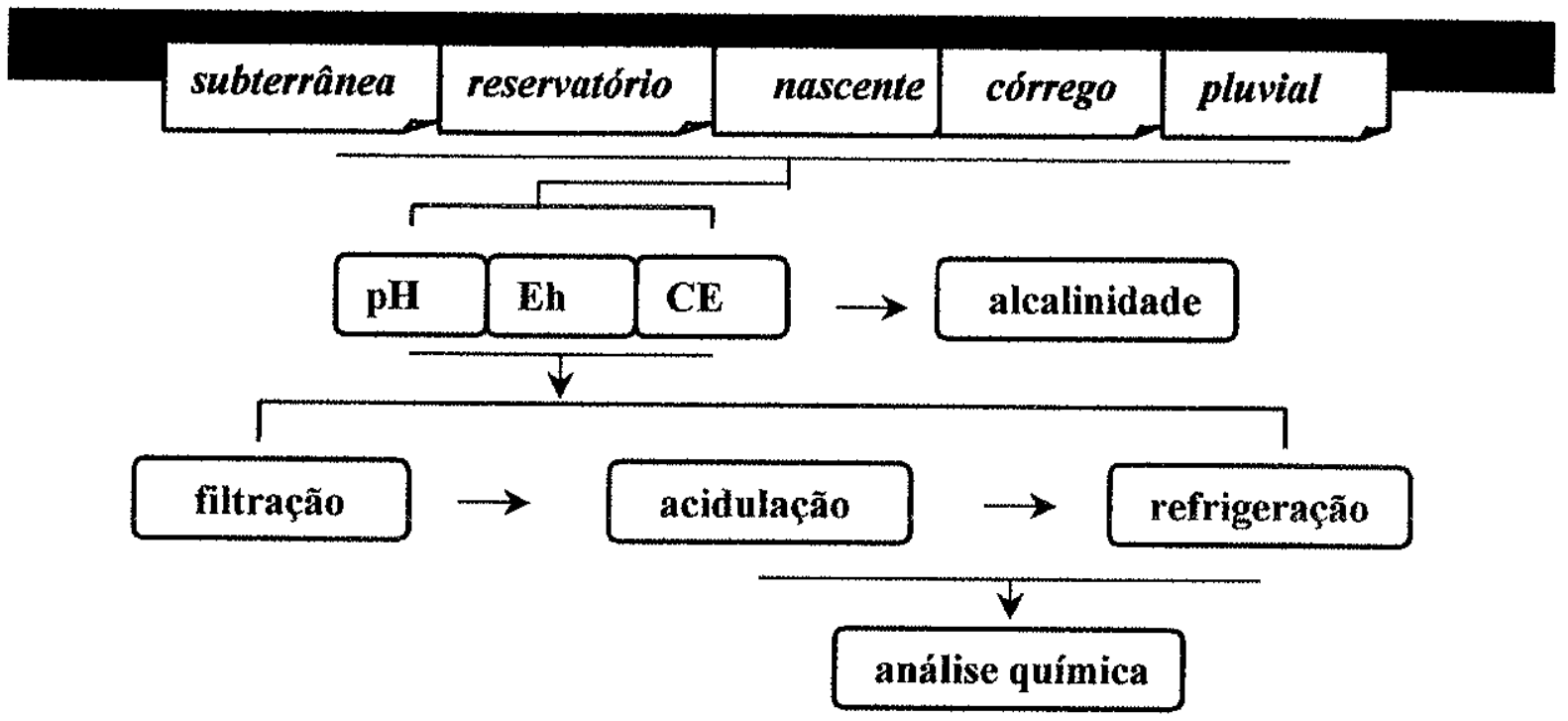

FIGURA 6.19. Fluxograma de fases no tratamento de amostras em solução

Os trabalhos de monitoração foram efetuados mensalmente, no entanto, selecionaram-se os meses de abril, maio e julho, como representativos das estações seca e chuvosa do ano de 1998 , bem como de maior intensificação no tratamento dos cultivares.

A temperatura média do ar manteve-se próxima a $21^{\circ} \mathrm{C}$, na estação seca, e a $26{ }^{\circ} \mathrm{C}$ na chuvosa. Os resultados analíticos dos constituíntes maiores das águas, como representativas do meio amostrado, são apresentados nas tabelas 6.21 a 6.26. Foram realizados balanços de massa iônica com objetivo de verificar a confiabilidade dos resultados pela defínição do erro prático. $O$ balanço de massa iônica foi calculado a partir de valores em miliequivalentes de cátions e ânions e comparados a condutividade elétrica medida (CUSTÓDIO \& LLAMAS, 1983). 
TABELA 6.21 - Resultados analíticos das águas pluvial, de superficie e aqüifero amostradas em abril de 1998

\begin{tabular}{|c|c|c|c|c|c|c|c|c|c|c|c|c|c|c|c|}
\hline \multirow[t]{2}{*}{$\mathbf{P A}$} & \multirow[t]{2}{*}{$(x$} & \multirow[t]{2}{*}{ y) } & STD & $C E$ & pH & Eh & $\mathrm{HCO}_{3}^{-}$ & $\mathrm{SO}^{2-}$ & $\mathrm{Cr}$ & $\mathrm{NO}_{3}^{-}$ & $\mathrm{Na}^{+}$ & $\mathbf{K}^{+}$ & $\mathrm{Ca}^{2+}$ & $\mathbf{M g}^{3+}$ & $\mathbf{E}$ \\
\hline & & & mg. $\mathrm{L}^{-1}$ & $\mu \mathrm{S} . \mathrm{cm}^{-1}$ & - & $\mathbf{V}$ & mg. $L^{-1}$ & mg. $L^{-1}$ & mg. $L^{-1}$ & mg. $\mathrm{L}^{-1}$ & mg.t. & mg..$^{-1}$ & $\mathbf{m g} \cdot \mathbf{L}^{-1}$ & mg.. ${ }^{-1}$ & $\%$ \\
\hline $\mathbf{P} \mathbf{M}_{(\mathrm{I})}$ & 313450 & 7441670 & 195,65 & 264,42 & 7,32 & $+0,30$ & 32,28 & 38,20 & 28,22 & 48,03 & 19,29 & 24,39 & 10,32 & 12,69 & 2,20 \\
\hline $\mathbf{P} \mathbf{M}_{(\mathrm{II})}$ & 313440 & 7441750 & 187,07 & 252,84 & 5,85 & $+0,15$ & 17,87 & 89,11 & 26,02 & 25,22 & 30,19 & 26,24 & 22,92 & 12,47 & 1,96 \\
\hline $\mathbf{P C}_{(\mathrm{II})}$ & 313530 & 7441760 & 151,48 & 204,73 & 6,89 & $+0,29$ & 26,07 & 36,03 & 26,45 & 59,72 & 11,85 & 28,94 & 19,32 & 14,24 & 0,00 \\
\hline SR & 313400 & 7441610 & 196,98 & 266,21 & 4,96 & $+0,33$ & 17,82 & 13,63 & 70,91 & 87,74 & 23,81 & 24,77 & 10,26 & 23,25 & 1,36 \\
\hline $\mathrm{CT}$ & 313370 & 7441680 & 37,19 & 50,26 & 5,98 & $+0,12$ & 19,78 & 1,32 & 4,75 & 2,254 & 3,72 & 3,21 & 2,71 & 3,15 & 9,56 \\
\hline $\mathbf{R}_{\mathbf{1}}$ & 313410 & 7441740 & 398,05 & 537,90 & 6,19 & $+0,30$ & 21,76 & 31,45 & 153,06 & 109,01 & 37,84 & 71,08 & 34,19 & 39,34 & 3,15 \\
\hline $\mathbf{R}_{2}$ & 313410 & 7441730 & 220,07 & 297,41 & 9,98 & $+0,25$ & 96,87 & 26,05 & 46,02 & 38,90 & 21,68 & 16,44 & 24,63 & 19,74 & 2,06 \\
\hline $\mathbf{R}_{3}$ & 313412 & 7441730 & 149,11 & 201,54 & 6,33 & $+0,28$ & 42,89 & 14,02 & 55,55 & 12,50 & 25,46 & 21,34 & 12,23 & 10,16 & 5,98 \\
\hline chuva & - & - & 50,69 & 68,54 & 5,36 & $+0,13$ & 6,29 & 26,01 & 5,51 & 6,19 & 3,97 & 11,47 & 5,24 & 2,22 & 0,56 \\
\hline
\end{tabular}

Nota: PA (ponto de amostragem); $\mathbf{x}, \mathbf{y}$ (coordenadas geográficas); $\mathbb{E}$ (erro prático) 
TABELA 6.22- Resultados analíticos das águas pluvial, de superficie e aqüifero amostradas em maio de 1998

\begin{tabular}{|c|c|c|c|c|c|c|c|c|c|c|c|c|c|c|c|}
\hline \multirow[t]{2}{*}{$\mathbf{P A}$} & \multirow[t]{2}{*}{$(x$} & \multirow[t]{2}{*}{ y) } & STD & $\mathbf{C E}$ & $\mathbf{p H}$ & $\mathbf{E h}$ & $\mathrm{HCO}_{3}^{-}$ & $\mathrm{SO}^{2-}$ & $\mathrm{Cl}^{-}$ & $\mathrm{NO}_{3}^{-}$ & $\mathrm{Na}^{+}$ & $\mathbf{K}^{+}$ & $\mathrm{Ca}^{2+}$ & $\mathbf{M g}^{2+}$ & $\mathbf{E}$ \\
\hline & & & mg.. ${ }^{-1}$ & $\mu \mathrm{S} . \mathrm{cm}^{-1}$ & - & $\mathbf{V}$ & mg. $L^{-1}$ & mg..$^{-1}$ & mg. $\mathbf{L}^{-1}$ & $\mathbf{m g} \cdot \mathbf{L}^{-1}$ & $\mathbf{m g} \cdot \mathbf{L}^{-1}$ & $\mathbf{m g . L ^ { - 1 }}$ & mg.. $\mathrm{L}^{-1}$ & mg.L. ${ }^{-1}$ & $\%$ \\
\hline $\mathbf{P M}(\mathbf{M})$ & 313450 & 7441670 & 57,94 & 78,34 & 6,88 & $+0,23$ & 23,32 & 6,61 & 5,58 & 8,51 & 5,06 & 2,88 & 6,24 & 3,97 & 6,90 \\
\hline $\mathbf{P} \mathbf{M}_{(\mathrm{II})}$ & 313440 & 7441750 & 40,11 & 54,24 & 5,80 & $+0,16$ & 20,52 & 0,66 & 1,55 & 3,08 & 3,35 & 2,76 & 2,93 & 1,93 & 8,33 \\
\hline $\mathbf{P C}_{(\mathrm{Im})}$ & 313530 & 7441760 & 51,59 & 69,72 & 6,99 & $+0,12$ & 31,34 & 1,66 & 2,14 & 0,98 & 2,39 & 2,21 & 9,42 & 1,27 & 8,82 \\
\hline $\mathbf{S R}$ & 313400 & 7441610 & 38,37 & 51,85 & 4,72 & $+0,15$ & 13,54 & 5,23 & 3,06 & 7,11 & 2,95 & 7,90 & 2,34 & 1,90 & 7,96 \\
\hline $\mathrm{CT}$ & 313370 & 7441680 & 33,63 & 45,45 & 5,97 & $+0,22$ & 20,84 & 2,46 & 2,05 & 0,52 & 1,81 & 5,58 & 1,67 & 0,82 & 2,72 \\
\hline $\mathbf{R}_{\mathbf{1}}$ & 313410 & 7441740 & 23,09 & 31,22 & 6,27 & $+0,19$ & 12,20 & 1,04 & 3,23 & 0,74 & 3,02 & 4,45 & 0,94 & 0,42 & 1,59 \\
\hline $\mathbf{R}_{2}$ & 313410 & 7441730 & 103,15 & 139,39 & 9,02 & $+0,20$ & 83,18 & 1,81 & 6,53 & 5,79 & 5,51 & 5,77 & 21,99 & 3,09 & 1,76 \\
\hline $\mathbf{R}_{\mathbf{3}}$ & 313412 & 7441730 & 46,25 & 62,52 & 6,84 & $+0,18$ & 19,30 & 2,11 & 6,66 & 4,24 & 4,84 & 4,44 & 2,33 & 3,61 & 7,46 \\
\hline chuva & - & - & 12,06 & 16,31 & 6,32 & $+0,09$ & 1,28 & 1,62 & 0,96 & 0,74 & 0,97 & 0,69 & 0,79 & 0,14 & 5,26 \\
\hline
\end{tabular}

Nota: PA (ponto de amostragem); $\mathbf{x , y}$ (coordenadas geográficas); $\mathbf{E}$ (erro prático) 
TABELA 6.23 - Resultados analíticos das águas pluvial, de superficie e aqüifero amostradas em julho de 1998

\begin{tabular}{|c|c|c|c|c|c|c|c|c|c|c|c|c|c|c|c|}
\hline $\mathbf{P A}$ & $(\mathrm{x}$ & y) & STD & CE & pH & $\mathbf{E h}$ & $\mathrm{HCO}_{3}^{-}$ & SO4 $4^{2-}$ & $\mathrm{Cr}$ & $\mathrm{NO}_{3}^{-}$ & $\mathrm{Na}^{+}$ & $\mathbf{K}^{+}$ & $\mathbf{C a}^{2+}$ & $\mathbf{M g}^{2+}$ & E \\
\hline & & & $\mathbf{m g} . \mathrm{L}^{-1}$ & $\mu \mathrm{S} . \mathrm{cm}^{-1}$ & - & V & mg. $\mathbf{L}^{-1}$ & $\mathbf{m g} . \mathrm{L}^{-1}$ & mg. $\mathrm{L}^{-1}$ & mg..$^{-1}$ & mg. $L^{-1}$ & $\mathbf{m g} . \mathbf{L}^{-1}$ & mg..$^{-1}$ & mg. $L^{-1}$ & $\%$ \\
\hline $\mathbf{P} \mathbf{M}_{(\mathrm{N})}$ & 313450 & 7441670 & 77,99 & 105,4 & 7,29 & $+0,28$ & 58,34 & 1,25 & 2,44 & 3,79 & 6,02 & 2,89 & 12,34 & 2,87 & 3,06 \\
\hline $\mathbf{P} \mathbf{M}_{(\mathrm{III})}$ & 313440 & 7441750 & 35,49 & 47,97 & 6,27 & $+0,21$ & 19,78 & 1,05 & 1,94 & 5,02 & 3,57 & 3,09 & 3,04 & 2,04 & 7,84 \\
\hline $\mathbf{P C}_{(\mathrm{II})}$ & 313530 & 7441760 & 32,01 & 43,26 & 6,78 & $+0,11$ & 22,71 & 3,96 & 2,45 & 1,02 & 3,02 & 2,41 & 4,07 & 2,43 & 4,42 \\
\hline SR & 313400 & 7441610 & 40,32 & 54,49 & 5,70 & $+0,18$ & 12,42 & 4,96 & 4,15 & 8,02 & 3,07 & 6,79 & 2,10 & 2,93 & 8,47 \\
\hline CT & 313370 & 7441680 & 33,43 & 45,18 & 5,25 & $+0,19$ & 19,71 & 3,21 & 4,06 & 2,71 & 1,97 & 5,78 & 2,07 & 2,39 & 1,96 \\
\hline $\mathbf{R}_{1}$ & 313410 & 7441740 & 34,83 & 47,07 & 6,20 & $+0,19$ & 13,42 & 2,03 & 4,26 & 4,47 & 3,74 & 3,27 & 1,87 & 2,43 & 8,16 \\
\hline $\mathbf{R}_{2}$ & 313410 & 7441730 & 118,92 & 160,77 & 10,02 & $+0,18$ & 87,25 & 2,72 & 7,23 & 6,77 & 5,98 & 5,02 & 24,07 & 2,85 & 5,55 \\
\hline $\mathbf{R}_{3}$ & 313412 & 7441730 & 29,38 & 39,72 & 6,95 & $+0,14$ & 20,76 & 2,63 & 6,11 & 3,87 & 3,99 & 3,44 & 2,78 & 3,65 & 4,54 \\
\hline chuva & - & - & 7,69 & 10,42 & 5,12 & $-0,10$ & 1,07 & 1,13 & 0,83 & 0,86 & 1,23 & 0,82 & 0,28 & 0,04 & 6,66 \\
\hline
\end{tabular}


TABELA 6.24 - Resultados analíticos da água da zona não-saturada amostradas em abril de 1998

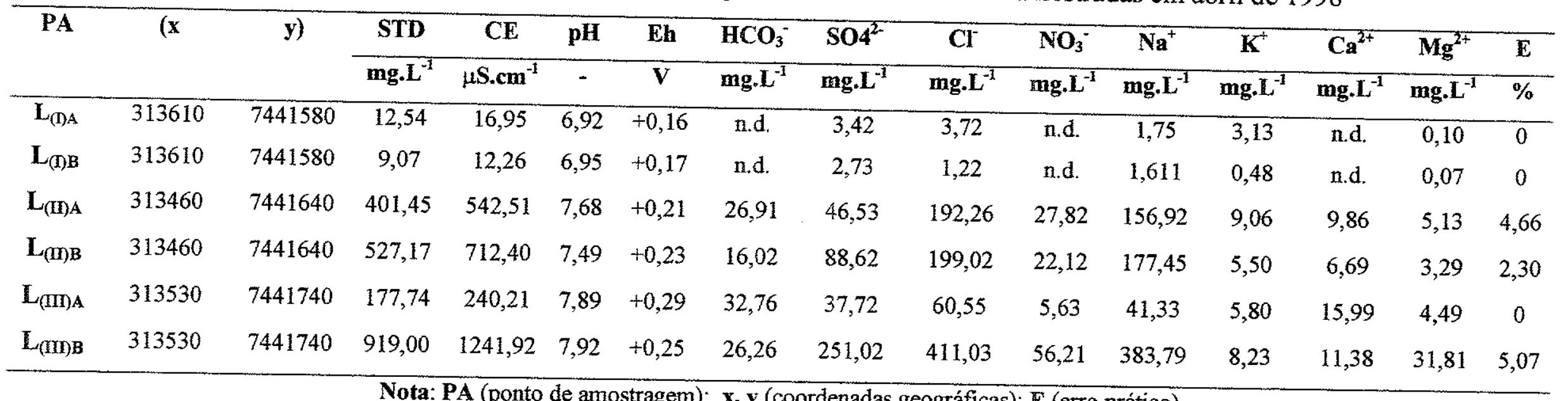

Nota: PA (ponto de amostragem); $\mathbf{x}, \mathbf{y}$ (coordenadas geográficas); $\mathbb{E}$ (erro prático) 
TABELA 6.25 - Resultados analíticosda água da zona não-saturada amostradas em maio de 1998

\begin{tabular}{|c|c|c|c|c|c|c|c|c|c|c|c|c|c|c|c|}
\hline \multirow[t]{2}{*}{$\mathbf{P A}$} & \multirow[t]{2}{*}{$(x$} & \multirow[t]{2}{*}{ y) } & STD & CE & $\mathrm{pH}$ & $\mathbf{E h}$ & $\mathrm{HCO}_{3}^{-}$ & $\mathrm{SO}^{2-}$ & $\mathrm{Cr}$ & $\mathrm{NO}_{3}^{-}$ & $\mathrm{Na}^{+}$ & $\mathbf{K}^{+}$ & $\mathrm{Ca}^{2+}$ & $\mathbf{M g}^{2+}$ & $\mathbf{E}$ \\
\hline & & & mg...-1 & $\mu \mathrm{S} . \mathrm{cm}^{-1}$ & - & $\vec{V}$ & $\mathbf{m g} \cdot \mathrm{L}^{-1}$ & $\mathbf{m g} \cdot \mathrm{L}^{-1}$ & mg.L $L^{-1}$ & mg...-1 & $\mathrm{mg} \cdot \mathrm{L}^{-1}$ & mg.t.-1 & $\mathrm{mg} \cdot \mathrm{L}^{-1}$ & mg. $L^{-1}$ & $\%$ \\
\hline $\mathbf{L}_{(\mathrm{I}) \mathrm{A}}$ & - & - & - & - & $\cdot$ & - & - & - & - & - & - & - & - & - & - \\
\hline $\mathbf{L}_{(\mathbf{B})}$ & - & - & - & - & - & - & - & - & - & - & - & - & - & - & - \\
\hline $\mathbf{L}_{(\mathbf{I}) \mathbf{A}}$ & - & - & - & - & - & - & - & - & - & - & - & - & - & - & - \\
\hline $\mathbf{L}_{(\mathrm{I}) \mathrm{B}}$ & 313460 & 7441640 & 112,99 & 152,71 & 7,86 & $+0,12$ & 15,07 & 41,21 & 17,46 & 21,21 & 16,49 & 11,07 & 13,04 & 4,02 & 1,02 \\
\hline $\mathbf{L}_{(\mathrm{III}) \mathrm{A}}$ & 313530 & 7441740 & 163,76 & 221,33 & 7,59 & $+0,17$ & 18,07 & 34,02 & 70,76 & 19,62 & 46,85 & 14,72 & 12,23 & 3,88 & 0,45 \\
\hline $\mathbf{L}_{(\mathbf{I m B})}$ & 313530 & 7441740 & 91,90 & 124,23 & 6,88 & $+0,18$ & 13,29 & 42,02 & 18,93 & 1,18 & 26,99 & 3,02 & 5,56 & 4,82 & 7,82 \\
\hline
\end{tabular}

Nota: PA (ponto de amostragem); $\mathbf{x}, \mathbf{y}$ (coordenadas geográficas); $\mathbb{E}$ (erro prático) 
TABELA 6.26 - Resultados analíticos da água da zona não-saturada amostradas em julho de 1998

\begin{tabular}{|c|c|c|c|c|c|c|c|c|c|c|c|c|c|c|c|}
\hline $\mathbf{P A}$ & $(x$ & y) & STD & $\mathrm{CE}$ & pH & $\mathbf{E h}$ & $\mathrm{HCO}_{3}{ }^{-}$ & $\mathrm{SO}_{4}^{2-}$ & $\mathrm{CI}^{-}$ & $\mathrm{NO}_{3}{ }^{-}$ & $\mathbf{N a}^{+}$ & $\mathbf{K}^{+}$ & $\mathrm{Ca}^{2+}$ & $\mathbf{M g}^{2+}$ & $\mathbf{E}$ \\
\hline & & & $\mathrm{mg} \cdot \mathrm{L}^{-1}$ & $\mu$ S.cm $^{-1}$ & - & $\mathbf{V}$ & mg. $L^{-1}$ & mg. $\mathbf{L}^{-1}$ & mg.h - $^{-1}$ & mg. $\mathrm{L}^{-1}$ & mg..$^{-1}$ & mg.L $\mathbf{L}^{-1}$ & mg. $\mathrm{L}^{-1}$ & mg.t. & $\%$ \\
\hline $\mathbf{L}_{(\mathrm{(}) \mathrm{A}}$ & 313610 & 7441580 & 89,24 & 120,61 & 7,12 & $+0,21$ & 30,04 & 42,61 & 17,52 & 0,99 & 11,91 & 3,34 & 11,65 & 2,63 & 1,84 \\
\hline $\mathbf{L}_{(\mathrm{I}) \mathrm{B}}$ & 313610 & 7441580 & 87,83 & 118,72 & 7,09 & $+0,15$ & 21,78 & 34,92 & 9,82 & 0,76 & 12,20 & 3,51 & 13,17 & 6,42 & 8,71 \\
\hline$L_{(I) A}$ & 313460 & 7441640 & 80,36 & 108,61 & 6,55 & $-0,13$ & 11,09 & 9,61 & 22,81 & 8,96 & 17,25 & 1,62 & 4,43 & 2,17 & 1,69 \\
\hline $\mathbf{L}_{(\mathrm{I}) \mathrm{B}}$ & 313460 & 7441640 & 204,83 & 276,82 & 8,06 & $+0,16$ & 38,24 & 82,41 & 21,81 & 25,41 & 36,74 & 10,82 & 17,88 & 8,13 & 1,76 \\
\hline $\mathbf{L}_{(\mathrm{II}) \mathbf{A}}$ & 313530 & 7441740 & 109,82 & 148,43 & 6,59 & $-0,14$ & 12,29 & 15,95 & 22,93 & 37,62 & 29,53 & 3,35 & 5,65 & 2,88 & 2,48 \\
\hline $\mathbf{L}_{(\mathbf{m}) \mathrm{B}}$ & 313530 & 7441740 & 96,05 & 129,83 & 7,15 & $+0,18$ & 11,67 & 44,65 & 22,34 & 1,03 & 27,89 & 2,15 & 5,29 & 3,74 & 1,67 \\
\hline
\end{tabular}


Em abril de 1998, a água da zona saturada apresentou sólidos totais dissolvidos que variaram de 151,48 a $195,65 \mathrm{mg} . \mathrm{L}^{-1}$; em maio e julho do mesmo ano, os sais dissolvidos variaram de 32,01 a 77,99 mg. $\mathrm{L}^{-1}$.

No final da estação chuvosa (abril), os valores de sólidos totais dissolvidos provenientes dos lisímetros da Estação I foram muito baixos quando comparados aos demais lisímetros das outras estações. Esses resultados eram esperados, pela diferenciação no tratamento químico dado às outras estações, uma vez que a Estação de Referência isenta-se de culturas. Além disso, a Estação Experimental I encontrase no topo da encosta não estando sujeita a deposição de materiais por erosão superficial de arrastamento, como ocorre nas outras estações. Em maio não foi detectada a presença de água da zona não-saturada na Estação I e na camada superficial da Estação II. Em julho, os valores de STD apresentaram-se mais elevados, o que pode ser atribuído ao tratamento químico, seguido da queimada do bambuzeiro, condenado devido à presença de praga. Diante da aplicação da calda sulfocálcica, observaram-se condições redutoras na camada superficial dos solos das Estações Il e III, com possibilidade do As (V) reduzir-se a As (III), levando a mobilização do arsênio até a zona saturada. No mês de abril, as amostras das Estações II e III, apresentaram teores de nitrato $\left(\mathrm{NO}_{3}{ }^{-}\right)$acima dos limites de tolerância (10 mg. $\mathrm{L}^{-1}$ ), da mesma forma que concentrações elevadas de cloreto $\mathrm{e}$ sulfato. A principal fonte de nitrato está relacionada às atividades agrícolas com aplicação de adubos nitrogenados. O nitrato presente na água do aqüífero representa problema de contaminação.

$\mathrm{O}$ reservatório 2 apresentou em todos os períodos valores elevados de $\mathrm{pH}$, compatíveis com elevadas concentrações de $\mathrm{HCO}_{3}{ }^{-}$.

$$
\mathrm{CO}_{3(\mathrm{aq})}^{2-}+\mathrm{H}_{2} \mathrm{O}(\mathrm{l}) \longleftrightarrow \mathrm{HCO}_{3(\mathrm{aq})}^{-}+\mathrm{OH}_{(\mathrm{aq})}^{-}
$$


Segundo critério de condutividade elétrica para efeito de controle de qualidade de análises químicas, o balanço de massa iônica mostrou bom grau de confiabilidade nos resultados. Os valores obtidos da água dos poços foram transformados em meq. $\mathrm{L}^{-1}$ e suas porcentagens (cátions e ânions) projetadas em Diagrama Piper (figura 6.20). 


\section{DPA GRAMA DE PIPRR}

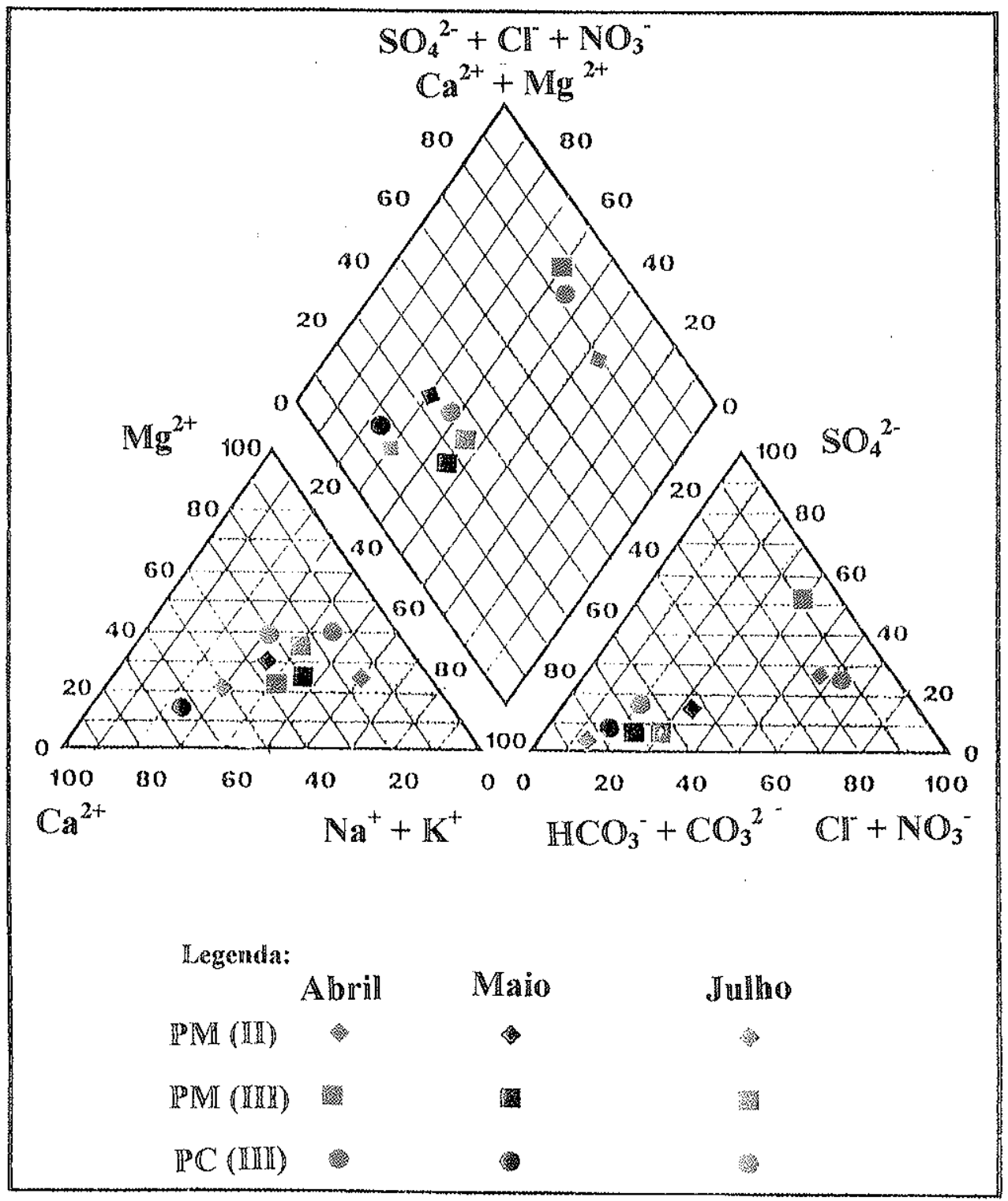

FIGURA 6.20 Projeção no Diagrama de Piper, em porcentagem de meq. $L^{-1}$ das amostras de água do aqüífero, em diferentes meses 
Constata-se, pelo Digrama de Piper, que as águas amostradas nos meses de abril, maio e julho de 1998, refletem a influência da sazonalidade climática. A classificação das águas do aqüífero, para os períodos amostrados, encontra-se no quadro 6.1.

QUADRO 6.1 - Classificação das águas da zona saturada para os meses amostrados segundo Diagrama de Piper

\begin{tabular}{|cccc|}
\hline PA & abril & maio & julho \\
\hline $\mathbf{P M}$ (II) & cloretada sódica & bicarbonatada cálcica & bicarbonatada cálcica \\
$\mathbf{P M}_{(\mathrm{III})}$ & sulfatada cálcica & bicarbonatada cálcica & bicarbonatada cálcica \\
$\mathbf{P C}_{\text {(III) }}$ & sulfatada cálcica & bicarbonatada cálcica & bicarbonatada cálcica \\
\hline
\end{tabular}

Em abril, a água do aqüifero foi classificada como cloretada-sulfatada, que é explicado devido à adubação de cobertura com sulfato de amônio e cloreto de potássio, realizada mensalmente de setembro a março de cada ano. 
De acordo com os dados pluviométricos do INSTITUTO AGRONÔNICO DE CAMPINAS - IAC (2000), o ano de 1998 não foi atípico no que se refere ao regime de chuvas, em relação às médias, nos últimos dez anos, para os meses que caracterizam o verão. A seguir, na figura 6.21 encontram-se as medições pluviométricas para o ano de 1998, no Município de Jundiaí.

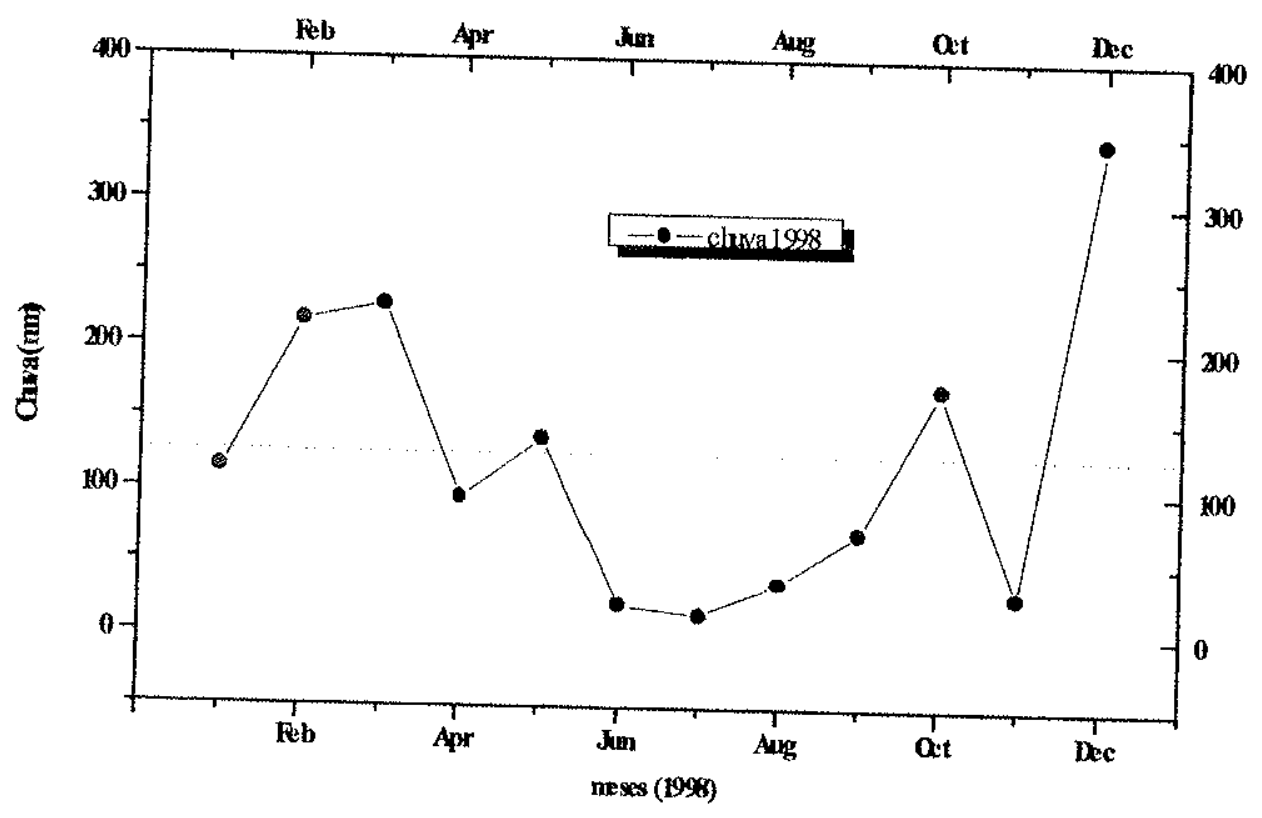

FIGURA 6.21. Precipitação pluviométrica mensal do ano de 1998, na zona rural do Município de Jundiaí (IAC, 2000) 
Os constituintes traço (arsênio, cromo, cobre, chumbo e mercúrio) determinados nas águas atmosférica, superficial e subterrânea, correpondentes aos três meses amostrados (abril, maio e julho de 1998), serão apresentados diretamente, na forma de diagrama, para melhor compreensão dos dados obtidos.

Os resultados obtidos foram comparados com a legislação em vigor segundo a Portaria $n^{\circ} 36$ (BRASIL, 1992), que estabelece padrões de potabilidade para águas destinadas ao consumo humano (tabela 6.27).

TABELA 6.27 - Limites máximos de tolerância para contaminantes inorgânicos em águas potáveis em mg. $\mathrm{L}^{-1}$

\begin{tabular}{|c|c|}
\hline elemento & mg. $L^{-t}$ \\
\hline As & 0,05 \\
\hline $\mathrm{Cr}$ & 0,05 \\
\hline $\mathrm{Cu}$ & 1,00 \\
\hline $\mathbf{P b}$ & 0,05 \\
\hline $\mathrm{Hg}$ & 0,001 \\
\hline
\end{tabular}

Nas águas, não foi possível quantificar o fósforo em baixas concentrações, visto que o método utilizado (cromatografia iônica) apresenta limite de deteç̧ão de $10 \mathrm{mg} \cdot \mathrm{L}^{-1}$. Da mesma forma, o mercúrio não foi detectado nas amostras de água, sendo também excluído nos diagramas.

A amostragem da água de superficie corresponde aos reservatórios $\left(R_{1}, R_{2} e\right.$ $\mathrm{R}_{3}$ ), à nascente $\mathrm{São}$ Roque (SR) e ao córrego da Toca (CT). Os resultados analíticos dos elementos $\mathrm{As}, \mathrm{Pb}, \mathrm{Cr}$ e Cu são apresentados na figura 6.22. 
Na zona não-saturada, a projeção gráfica dos metais pesados e arsênio na água acham-se na figura 6.23. A água dos poços também foi analisada quimicamente e os resultados são apresentados na figura 6.24.

Os resultados das análises químicas da água de chuva acham-se na tabela 6.28.

TABELA 6.28 - Resultados analíticos da água de chuva em ( $\left.\mu \mathrm{g} . \mathrm{L}^{-1}\right)$, amostrada nos meses abril, maio e julho de 1998

\begin{tabular}{cccc}
\hline constituinte & abril & maio & julho \\
\hline $\mathbf{A s}(\mathfrak{t )}$ & 2,77 & 0,21 & 0,16 \\
$\mathbf{C r}_{(\mathfrak{t})}$ & 2,40 & 1,62 & 0,66 \\
$\mathbf{P b}^{2+}$ & 1,60 & 1,75 & 1,43 \\
$\mathbf{C u}^{2+}$ & $0,47^{*}$ & 29,07 & 0,09 \\
\hline
\end{tabular}

Nota: 0 asterisco $\left({ }^{*}\right)$ representa teor em $m g . L^{-1}$ 


\section{ÁGUA DE SUPERFÍCIE}

\section{abril}

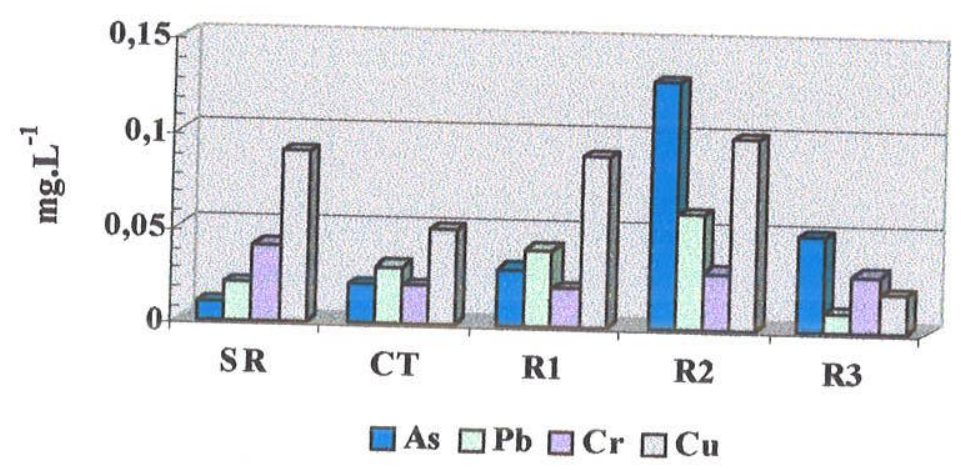

maio
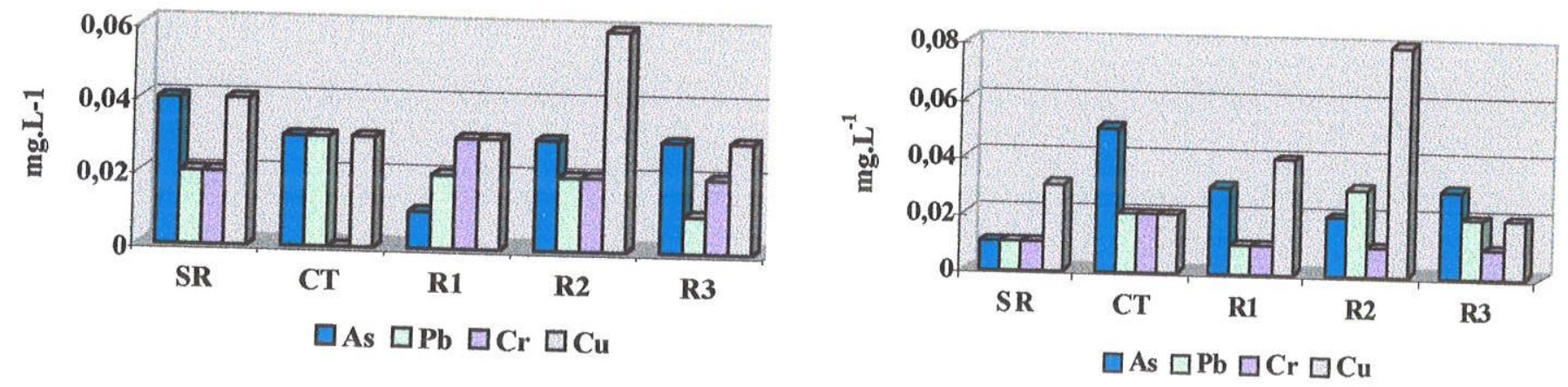

FIGURA 6.22. Resultados analíticos de arsênio, chumbo, cromo e cobre presentes na água de superfície nos meses de abril, maio e julho de 98 


\section{ÁGUA DA ZONA NÃO-SATURADA}

\section{abril}

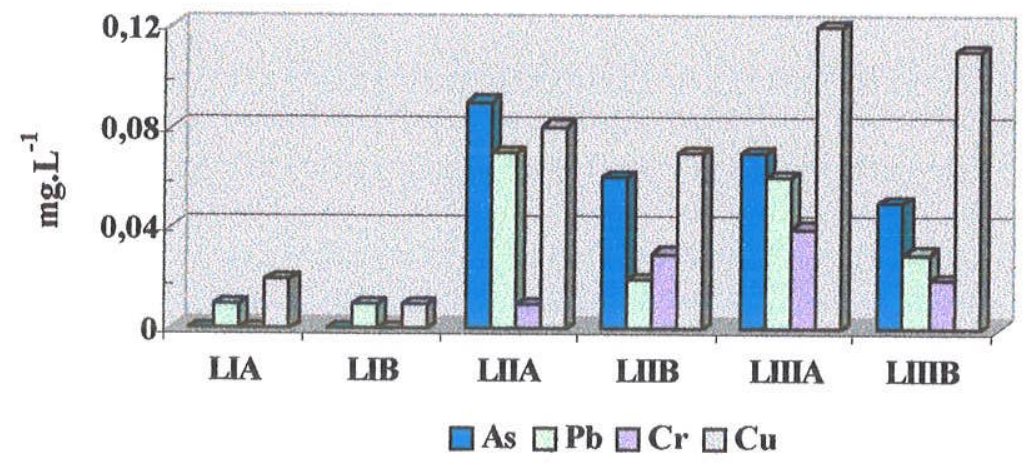

maio

julho

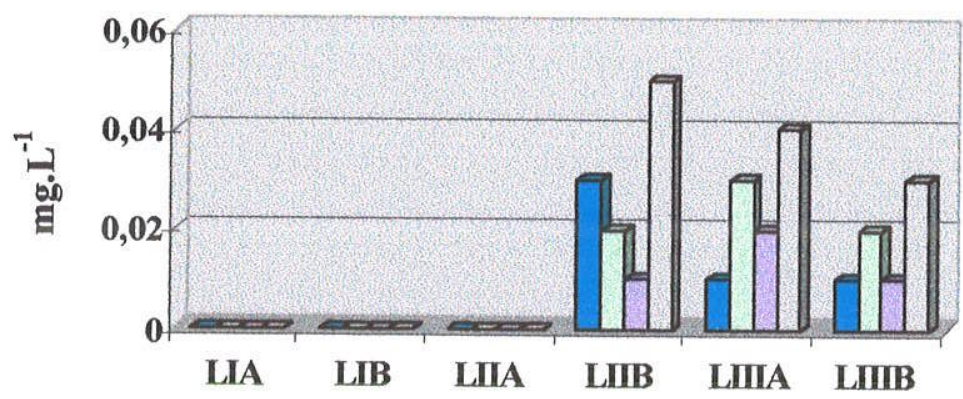

$\square$ As $\square \mathrm{Pb} \square \mathrm{Cr} \square \mathrm{Cu}$

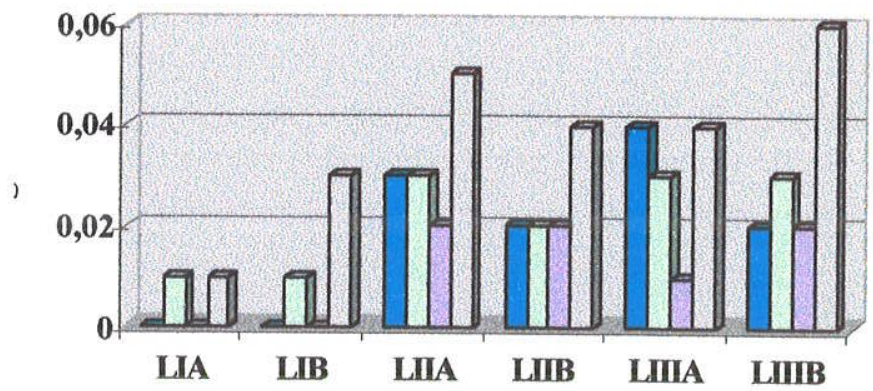

$\square$ As $\square \mathrm{Pb} \square \mathrm{Cr} \square \mathrm{Cu}$

(os pontos LIA, LIB e LIIA não foram amostrados no mês de maio)

FIGURA 6.23. Resultados analíticos de arsênio, chumbo, cromo e cobre presentes na água da zona não-saturada em abril, maio e julho de 1998 
A presença de cobre na água de chuva deve-se a pulverizações de produtos contendo o elemento. A calda de viçosa, por exemplo, utilizada como fungicida apresenta em sua composição sulfatos de cobre, zinco e magnésio.

A água dos reservatórios, apesar de ter sido analisada, não pode ser tomada como referência para se determinar o acréscimo de agentes contaminantes ao meio, uma vez que é utilizada para lavagem de equipamentos e maquinários usados na lavoura.

Os resultados analíticos da água do córrego da Toca e nascente São Roque revelam a presença pouco expressiva de íons metálicos e arsênio.

A contaminação da água acha-se estreitamente relacionada à ocorrência de elementos poluentes nos solos por ocasião dos tratamentos químicos realizados nos pomares.

Os íons arsênio, chumbo, cromo e cobre na zona não-saturada apresentam mobilidades semelhantes, comprovadas pelas extrações com água, água e gás carbônico e lisímetros de sucção. 


\section{COMPORTAMENTO EXPERIMENTAL DE As E P NO SOLO}

As reações de fósforo com os constituintes do solo, sob o ponto de vista da fertilidade e quimismo, têm sido extensivamente estudadas (SANYAL \& DE DATTA, 1991; YUAN \& LAVKULICH, 1994). Sabe-se que em solos ácidos, característicos da área de estudo, os óxidos e hidróxidos de ferro e alumínio são os constituintes que predominantemente influenciam na adsorção do fósforo (PARFITT, 1989; BORGGAARD et al. 1990). Da mesma forma, o arsênio tem sido bastante retratado diante de incidentes ocorridos em várias partes do mundo. Muitos pesquisadores relatam a mobilidade do arsênio no solo devido a competitividade aniônica, principalmente na presença do fósforo (LIVESEY \& HUANG, 1981; ROY et al. 1986; PERYEA, 1991 e MANNING \& GOLDBERG, 1996).

$\mathrm{O}$ arsênio e fósforo exibem similaridades químicas e competem diretamente nos processos de adsorção sobre os constituintes do solo. A imobilização tanto de arsênio quanto de fósforo pode ocorrer mediante fenômenos de sorção e troca iônica. Diante da competitividade aniônica entre P e As, cabe esclarecer que na maioria dos solos, a concentração do fósforo é muito mais elevada quando comparada ao arsênio. Este, ao contrário do fósforo, sofre influência do potencial de oxi-redução.

O comportamento entre arsenato e fosfato foi estudado mediante ensaios de retenção e, posteriormente, em coluna de infiltração. A seguir, com objetivo de verificar a capacidade de retenção de ambos, observados isoladamente e em mistura, foram realizados experimentos com adição de soluções contendo diferentes concentrações de arsênio, na forma de $\mathrm{KH}_{2} \mathrm{AsO}_{4}$ e fósforo como $\mathrm{KH}_{2} \mathrm{PO}_{4}$ em massa conhecida de material proveniente das Estações Experimentais. 
Os ensaios foram efetuados com amostras das Estą̧ões Experimentais coletadas a $30 \mathrm{~cm}$ de profundidade. A profundidade escolhida abrange a zona de maior influência no preparo e tratamento do solo.

Os teores dos ânions foram calculados com base nos dados fornecidos por RENZONI et al. (1994) que relatam níveis de As no solo entre 0,2 e $40 \mathrm{mg} \cdot \mathrm{kg}^{-1}$. Desta forma, selecionou-se a mesma faixa de concentração tanto para o As como para o $\mathrm{P}$ com teores de 0,$2 ; 2,0 ; 10,0 ; 20,0$ e $40,0 \mathrm{mg} \cdot \mathrm{L}^{-1}$. Inicialmente, as soluções foram adicionadas em 1,000 g de solo, provenientes de cada estação; em seguida, foram agitadas e mantidas em repouso por 15 minutos. Este tempo foi estabelecido em função de experimentos prévios que refletem picos de maior adsorção para os primeiros minutos de contato. Após o tempo pré-estabelecido, as soluções foram separadas por filtração e analisadas quimicamente.

As porcentagens de fixação de cada ânion em função de suas concentrações iniciais acham-se reunidas na figura 7.1. 

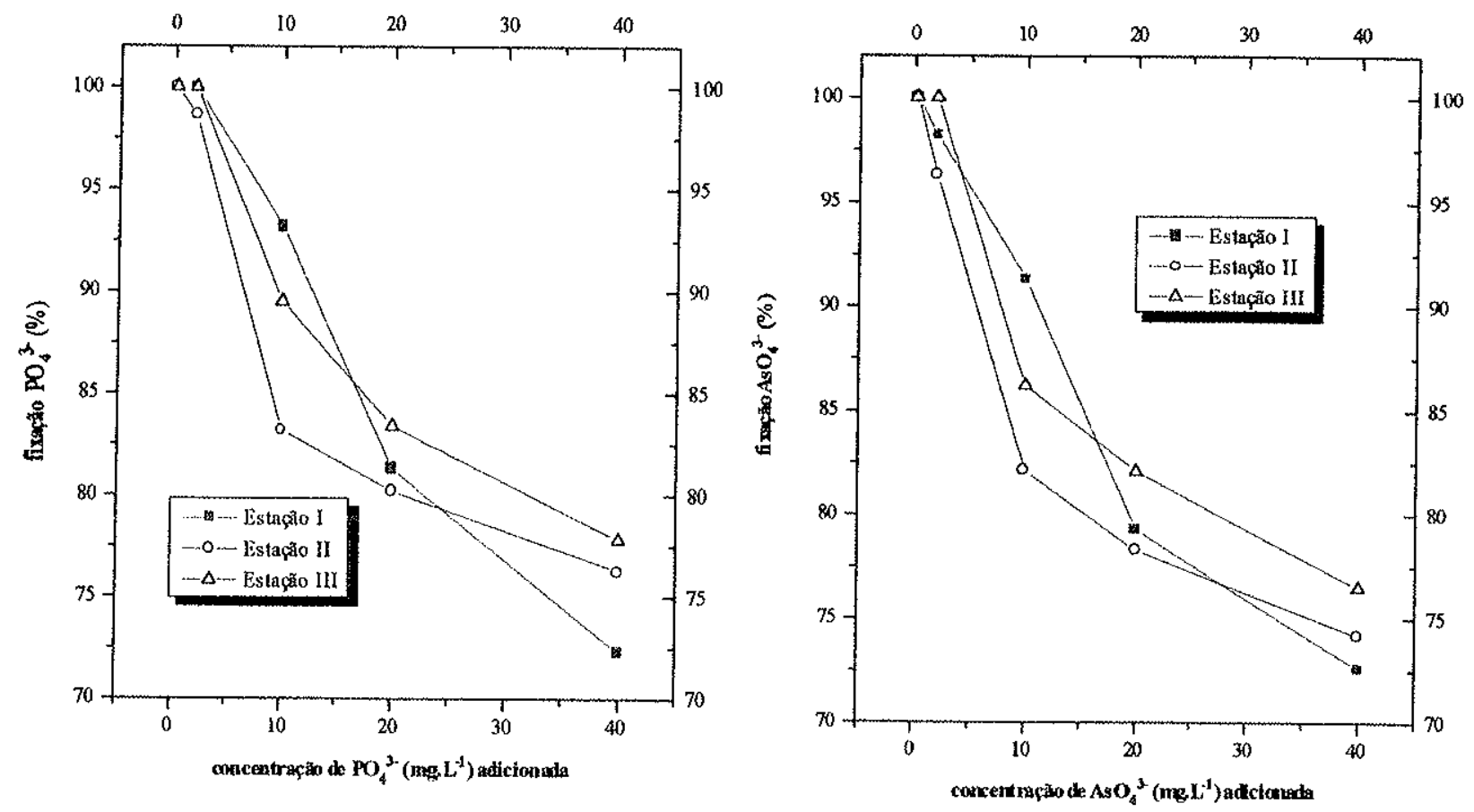

FIGURA 7.1. Teores de fosfato e arsenato assimilados em função da concentração de partida

A fixação dos ânions parece ser influenciada pela textura do solo e ausência de tratamento químico, observando-se maior adsorção nas Estações Experimentais I e III. A Estação I encontra-se isenta de resíduos que alterem a composição química do solo. A Estação III, por sua vez, apresenta solo uniforme, com maior porcentagem de argila em relação às demais. A retenção efetiva de ânions foi observada para baixos teores, em concentração inferior a $20 \mathrm{mg} . \mathrm{L}^{-1}$. A partir daí, verifica-se queda acentuada tanto para arsenato quanto fosfato. 
A seguir, foram realizados experimentos com a intenção de verificar o efeito de P sobre adsorção de As (V), em solo argilo-arenoso, procedente da Estação I.

Em béqueres contendo $1,000 \mathrm{~g}$ de solo, foi adicionada solução arsenatada $\left(0,25 \mathrm{mg} \cdot \mathrm{L}^{-1}\right)$, seguida de soluções fostatadas com teores que variaram de 0,25 a 2,5 mg. $\mathrm{L}^{-1}$. Como em solos agrícolas os teores de fósforo são superiores aos de arsênio, para este ensaio a concentração de fósforo foi estabelecida em dez vezes mais que o teor de arsênio. O tempo de residência solução/sólido foi de 30 minutos. Os valores obtidos de pH foram próximos a 6,6. Na figura 7.2 são fornecidos os resultados de As em \% em função da concentração de $P$.

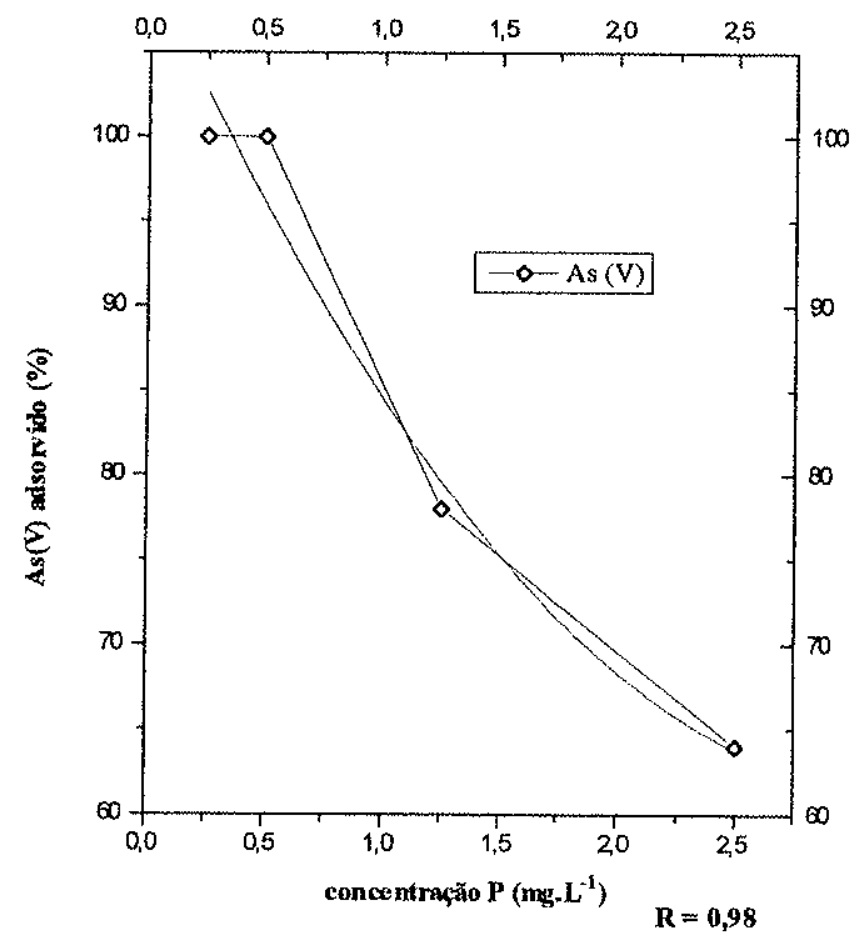

FIGURA 7.2. Teores de arsênio assimilados pelo solo em função do aumento da concentração de fósforo 
A presença de $2,5 \mathrm{mg} \cdot \mathrm{L}^{-1}$ de $\mathrm{P}$ causou decréscimo na adsorção do As, entretanto, a presença de 0,25 e $0,5 \mathrm{mg} \cdot \mathrm{L}^{-1}$ de $\mathrm{P}$ não teve efeito sobre adsorção de $\mathrm{As}$ pelos constituíntes do solo. $\mathrm{O}$ aumento da concentração de $\mathrm{P}$ na proporção 1:10 reduziu a adsorção do arsênio para $64 \%$, evidenciando que estes ânions competem entre si pelos mesmos sítios de adsorção.

Estes resultados servem como indicativo sobre os efeitos da competitividade entre arsenato $\left(\mathrm{H}_{2} \mathrm{AsO}_{4}{ }^{-}\right)$e fosfato $\left(\mathrm{H}_{2} \mathrm{PO}_{4}{ }^{-}\right)$quando em solução. Os elementos competem entre si, por sítios de adsorção ou, em condições naturais, por ligações complexantes disponiveis. Assim, a mobilidade do arsênio pode ser afetada pela concentração de fósforo em solução.

No solo, alta concentração localizada do ânion hidrogenofosfato pode desestabilizar ligações entre íons metálicos e minerais, propiciando a migração de elementos, como o arsênio, até a zona saturada. 


\section{CARACTERIZAÇÃo DOS AGROQUÚMICOS}

O sistema agrícola biocida, ainda fortemente dominante no país, condiciona o emprego de produtos altamente tóxicos, comprometendo a qualidade do meio ambiente e saúde do homem. Embora venha passando por profundas transformações, com sistemas de produção do tipo "alternativo", a agricultura ainda se depara com uso de pesticidas para minimizar a incidência de pragas e doenças.

A eficiência agrícola certamente encontra-se dependente da adição de fertilizantes fosfatados, principalmente em solos de baixa produtividade natural. Sob o ponto de vista econômico, o consumo de adubos sintéticos torna-se muito rentável e de grande interesse na fabricação e comercialização desses produtos.

A fertilização do solo inclui pelo menos 16 nutrientes essenciais ao desenvolvimento vegetal; entre eles, destacam-se os macronutrientes primários, como nitrogênio, fósforo e potássio, e os secundários, como cálcio, magnésio e enxofre. Entre os micronutrientes, têm-se zinco, manganês, cobre, ferro, molibdênio, boro e cloro.

Para melhor compreensão dos resultados analíticos que serão apresentados, encontra-se no quadro 9.1 o calendário de aplicação dos principais agroquímicos utilizados nos cultivares. Neste quadro, os pesticidas não são mencionados, uma vez que apresentam recomendações específicas de aplicação. 
QUADRO 8.1. Calendário de aplicação de agroquímicos em culturas de pêssego, no Sítio São Roque

\begin{tabular}{|cc|}
\hline produto & período (mês) \\
\hline NPK e yoorin & abril \\
calcário dolomítico & abril \\
esterco de galinha & abril \\
calda sulfocálcica & julho \\
*sulfato de amônio & de setembro a março \\
*cloreto de potássio & de setembro a março \\
\hline
\end{tabular}

* adubação de cobertura

Do depósito, foram coletados fertilizantes fosfatados, calcário dolomítico (utilizado na calagem), enxofre (constituínte da calda sulfocáícica) e pesticidas. Todos os produtos foram encaminhados para exame químico quanto aos teores de metais pesados e arsênio. A seguir, são tecidas considerações sobre os agroquímicos e apresentados os resultados analíticos. 


\section{PESTICIDAS}

Os pesticidas podem ser de natureza orgânica (organosintéticos como organoclorados, fosforados, clorofosforados, carbamatos, piretróides etc.) ou inorgânica (contendo metais pesados na composição química), repercutindo alta toxicidade ao meio e aos organismos vivos, diante da capacidade residual e cumulativa dos compostos.

No Brasil, existem vários termos empregados para identificar os produtos químicos utilizados nas culturas, os mais usuais são: pesticida, praguicida, agrotóxico e defensivo agrícola; este último, adotado somente pelo Ministério da Agricultura e Sindicato da Indústria de Defensivos Agrícolas (SINDAG). Neste estudo, para uso geral, decidiu-se pelo termo pesticida, independente da classificação segundo a finalidade: herbicida, fungicida, formicida, acaricida, raticida, entre outros.

Na primeira metade da década de vinte, o Sítio São Roque começava a se formar trazendo em sua paisagem as videiras. Naquele tempo, o país estava mergulhado na "era dos fumegantes inorgânicos". Mais tarde, final da década de sessenta, na "era dos hormônios e ferormônios"; já a década de noventa, foi assinalada pela intensa discussão sobre os alimentos transgênicos.

O histórico dos pesticidas revela que o sistema agrícola tradicional esteve associado ao uso maciço de agroquímicos com alto poder devastador-poluidor.

$\mathrm{O}$ aporte tecnológico tem acelerado o processo de renovação dos biocidas e nos últimos anos, vem crescendo o interesse na adoção de práticas agroecológicas. Alimentos com boa qualidade biológica, livres de resíduos tóxicos, já estão sendo produzidos segundo técnicas e princípios da Agricultura Orgânica.

A constatação da presença de elementos como $\mathrm{As}, \mathrm{Pb}, \mathrm{Cr}, \mathrm{Cu}$ e $\mathrm{Hg}$ nas zonas saturada e não-saturada do Sítio São Roque, exigiu a realização de análises químicas dos produtos químicos utilizados no campo. 
Os pesticidas amostrados no sítio São Roque foram relacionados de acordo com a classe e fabricante (quadro 8.2). Estes produtos, utilizados nos mais diversos tratamentos preventivo, curativo e erradicante, são aplicados nos cultivares conforme dosagem recomendada pelo fabricante.

QUADRO 8.2. Produtos químicos utilizados nas culturas do Sítio São Roque

\begin{tabular}{|ccc|}
\hline produto & classe & fabricante \\
\hline Dithane M-45 & Fungicida & Rohm \& Haas \\
Bravik 600 CE & Inseticida/Acaricida & Sanachen do Brasil \\
Glifosato & Herbicida & Nortox S.A. \\
Captan 500 PM & Fungicida & Zeneca Brasil \\
Systhane & Fungicida & Rohm \& Haas \\
Tamaron & Inseticida & Bayer S. A. \\
Lebaycid 500 & Inseticida/Acaricida & Bayer S. A. \\
Gramoxone 200 & Herbicida & Zeneca Brasil \\
Vertimec 18 CE & Acaricida/Inseticida & Merck \& Co \\
Roundup & Herbicida & Monsanto do Brasil Ltda \\
Supracid 400 & Inseticida & Ciba-Geigh \\
Match & Acaricida/Inseticida & Novartis \\
Benlate 500 & Fungicida & Du Pont do Brasil S.A. \\
Sialex 500 & Fungicida & Hokko do Brasil Ltda \\
Confidor 700 GRDA & Inseticida & Bayer S.A. \\
& & \\
\hline
\end{tabular}

Os resultados de análise química destes produtos, tanto em solução como em pó, são apresentados na tabela $8.1 \mathrm{e}$, posteriormente, projetados graficamente na figura 8.1. Os produtos acham-se dispostos em ordem alfabética, para que não se identifique a procedência. 
TABELA 8.1 - Resultados analíticos dos pesticidas estocados no Sítio São Roque

\begin{tabular}{|c|c|c|c|c|c|}
\hline amostra & As & $\mathrm{Cr}$ & $\mathbf{C u}$ & $\mathbf{P b}$ & $\mathbf{H g}$ \\
\hline $\mathbf{A}^{*}$ & 0,34 & 8,68 & 0,88 & 27,08 & 3,19 \\
\hline $\mathbf{B}^{*}$ & 0,34 & 5,13 & 1,69 & $\mathbf{3 7 , 5 0}$ & 1,79 \\
\hline$C^{*}$ & $\mathbf{0 , 3 3}$ & 3,75 & 1,63 & 24,30 & 0,98 \\
\hline $\mathbf{D}^{*}$ & $\mathbf{0 , 3 1}$ & 2,56 & $\mathbf{0 , 8 2}$ & $\mathbf{3 3 , 3 3}$ & 1,21 \\
\hline $\mathbf{E}^{*}$ & 0,26 & 2,07 & 0,78 & 20,83 & 1,79 \\
\hline$F^{*}$ & 0,26 & 3,65 & 0,96 & 16,66 & 1,75 \\
\hline$G^{*}$ & $\mathbf{0 , 3 3}$ & $\mathbf{5 , 5 2}$ & 0,98 & 34,72 & 1,89 \\
\hline $\mathbf{H}^{*}$ & $\mathbf{0 , 3 3}$ & 4,14 & 1,18 & 40,27 & 1,06 \\
\hline$I^{*}$ & $\mathbf{0 , 3 1}$ & 2,46 & 0,96 & 27,28 & 0,80 \\
\hline $\mathbf{J}^{\star}$ & 0,34 & 5,42 & 0,94 & 25,69 & 1,90 \\
\hline $\mathbf{K}^{*}$ & $\mathbf{1}, 46$ & 14,79 & 3,89 & 56,94 & 3,47 \\
\hline $\mathbf{L}^{* *}$ & 0,58 & $\mathbf{3 , 5 5}$ & 2,06 & 56,94 & 1,73 \\
\hline $\mathbf{M}^{* * *}$ & 0,63 & 5,92 & 2,51 & 40,27 & 1,84 \\
\hline $\mathbf{N}^{* *}$ & 0,63 & 5,72 & 2,71 & 47,22 & 1,78 \\
\hline $\mathbf{O}^{* *}$ & 0,62 & 3,94 & 2,14 & 76,38 & 1,75 \\
\hline
\end{tabular}

Os resultados analíticos mostram a presença de constituintes de interesse em todos os produtos. 


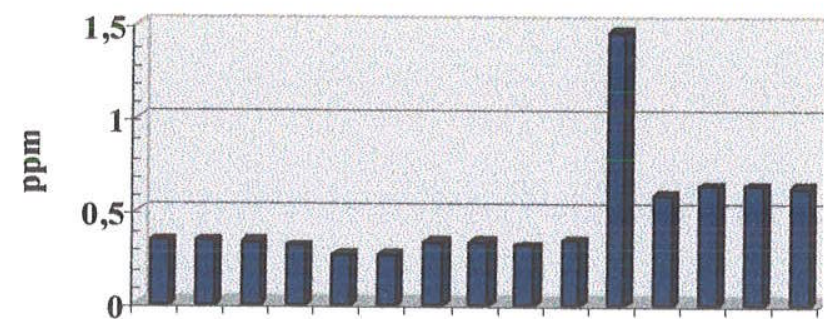

$\begin{array}{lllllllllllllllll}\text { A } & B & C & D & \text { E } & \text { F } & G & \text { H } & \text { I } & J & K & L & M & \mathbf{N} & \mathbf{O}\end{array}$

口As

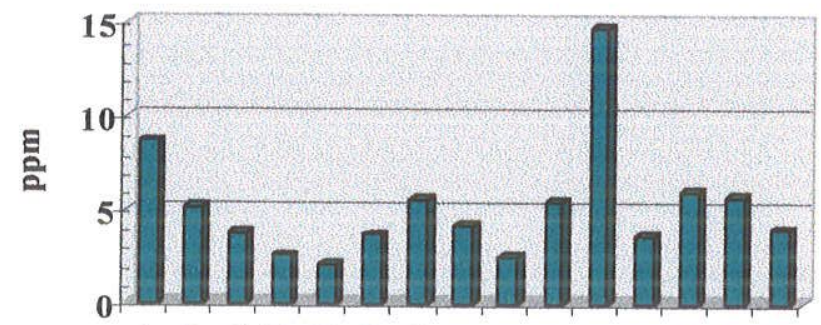

$\begin{array}{llllllllllllllll}A & \text { B } & C & D & \text { E } & \text { F } & G & \text { H } & \text { I } & \text { J } & K & L & \text { M } & \text { N } & \text { O }\end{array}$

$\square \mathrm{Cr}$

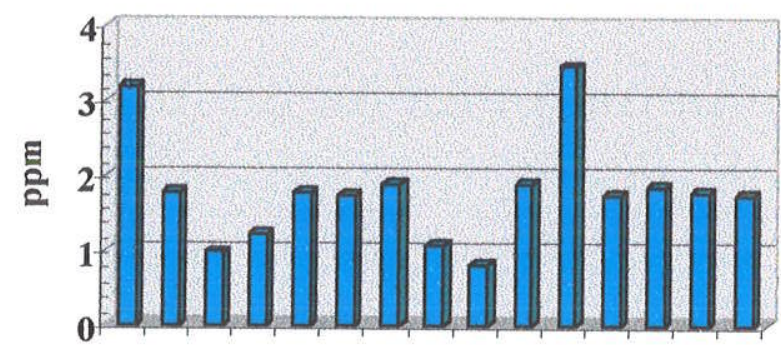

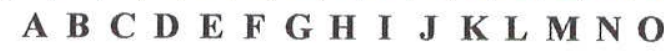

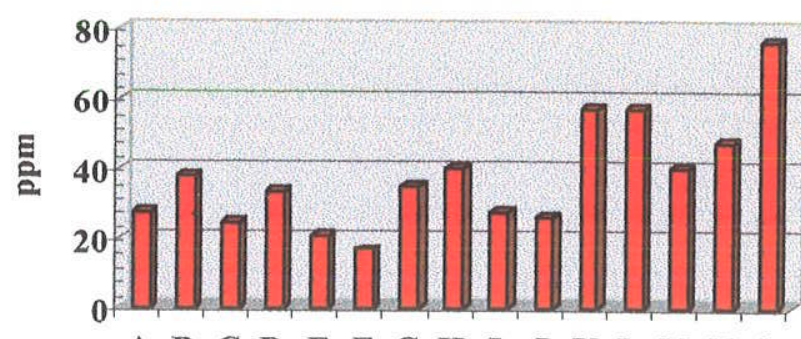

$\begin{array}{lllllllllllllllll}\text { A } & \text { B } & C & \text { D } & \text { E } & \text { F } & G & \text { H } & \text { I } & \text { J } & K & \text { K } & \text { L } & \text { M } & \mathbf{N} & \mathbf{O}\end{array}$

$\square \mathbf{P b}$

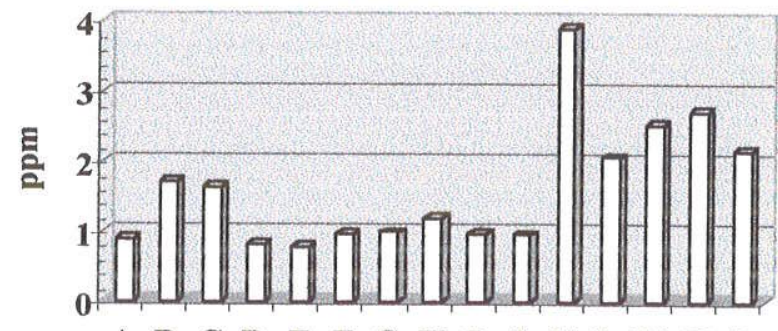

$\begin{array}{llllllllllllllll}A & \text { B } & C & D & \text { E } & \text { F } & G & \text { H } & \text { I } & J & K & L & M & \text { N } & \text { O }\end{array}$

$\square \mathrm{Cu}$

\section{$\square \mathrm{Hg}$}

FIGURA 8.1. Resultados analíticos de As e metais pesados nos pesticidas amostrados no Sítio São Roque 


\section{CALDA SULFOCÁLCICA}

O fungicida denominado calda sulfocálcica é utilizado nas culturas, no período de inverno, antes da poda anual. No preparo da calda, utiliza-se a proporção 10:2:1 de água, enxofre e cal, respectivamente.

Deste fungicida, foram analisados os componentes de interesse (As, $\mathrm{Cr}, \mathrm{Cu}$ $\mathrm{Pb}$ e $\mathrm{Hg}$ ) no produto "enxofre", uma vez que é matéria-prima de grande parte dos agroquímicos. A amostra de enxofre foi coletada no momento da preparação da calda sulfocálcica.

O enxofre é conhecido como o sexto elemento essencial às plantas e como o nitrogênio, entra na constituição de proteínas. Os vegetais absorvem o enxofre do solo na forma aniônica, como sulfato $\left(\mathrm{SO}_{4}{ }^{2-}\right)$, produto de sua oxidação.

Os resultados analíticos do "enxofre", utilizado no preparo da calda sulfocálcica, são apresentados na figura 8.2 .

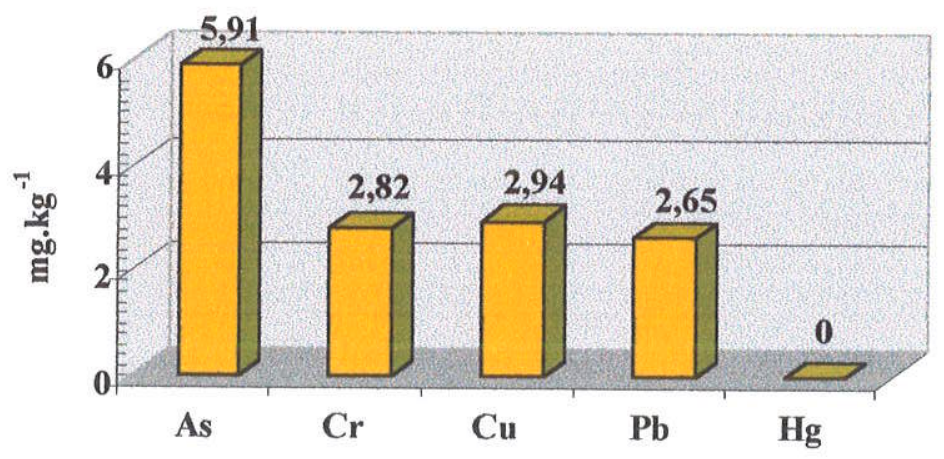

Nota: $n$.d., não detectado (limite de detecção: $\mathrm{Hg}<0,001 \mu \mathrm{g} \cdot \mathrm{kg}^{-1}$ )

FIGURA 8.2. Resultados analíticos de arsênio e metais pesados em amostra de

$$
\text { "enxofre" (mg.kg-1) }
$$


Em relação ao comércio do enxofre, o Canadá é tido como maior produtor e exportador mundial. Seu produto é de alta qualidade e reconhecidamente isento de elementos como selênio (Se), telúrio (Te) e arsênio. O cartel do "enxofre" canadense inclui a Prism Sulphur Corporation, Shell Canada Limited, Husky Oil Operations Ltd, Amaco Canada Petroleum Company Ltd e Petrosul International Ltd.

A PRISM SULPHUR CORPORATION (1999) apresenta uma série de especificações em relação ao "enxofre" canadense, com pureza mínima de $99,8 \%$, sendo o teor máximo para arsênio estimado em de $0,25 \mathrm{mg} \cdot \mathrm{kg}^{-1}$.

Mesmo diante desta isenção de elementos contaminantes, como é difundido pelo setor exportador, o fato é que o arsênio pode estar presente no "enxofre", principalmente, quando comparado ao produto utilizado pelo sitiante na produção da calda sulfocálcica. 


\section{CALCÁRIO}

O calcário dolomítico, utilizado na calagem, também foi analisado quanto aos teores de arsênio e metais pesados. O carbonato de cálcio $\left(\mathrm{CaCO}_{3}\right)$ é uma fonte de álcali para o ajuste e controle de $\mathrm{pH}$ no solo. $\mathrm{O}$ produto comercializado na forma de pó foi encaminhado para análise química e os resultados são apresentados na tabela 8.2 .

TABELA 8.2 - Resultados analíticos de arsênio e metais pesados em amostra de calcário dolomítico

\begin{tabular}{cccccc}
\hline produto & $\mathbf{A s}$ & $\mathbf{C r}$ & $\mathbf{C u}$ & $\mathbf{P b}$ & $\mathbf{H g}$ \\
\hline calcário & n.d. & 3,85 & 1,01 & n.d. & n.d. \\
\hline
\end{tabular}

Nota: n.d., não detectado (limites de deteç̧ão: $\mathbf{A s}<0,2 \mathrm{mg} \cdot \mathrm{kg}^{-1} ; \mathbf{H g}<0,001 \mu \mathrm{g} \cdot \mathrm{kg}^{-1} \mathrm{e} \mathbf{P b}$

$$
1,5 \mathrm{mg} \cdot \mathrm{kg}^{-1} \text { ) }
$$

GABE \& RODELLA (1999) analisaram alguns metais pesados (cobre, chumbo e cromo) em calcário utilizado na cultura da soja, verificando que a maioria das amostras apresentou valores inferiores a $10 \mathrm{mg} \cdot \mathrm{kg}^{-1}$.

\section{FERTILIZANTES SINTÉTICOS}

Os fertilizantes sintéticos Can-Fal e Plant-Fal, bem como, o NPK (14:14:8) e Yoorin Master, aplicados nos solos do sítio São Roque, foram encaminhados para análise química. Os resultados analíticos de metais pesados e arsênio são apresentados na figura 8.3. Os resultados destes produtos são apresentados em ppm, visto que o produto Can-Fal é adquirido em solução enquanto os demais em pó. 

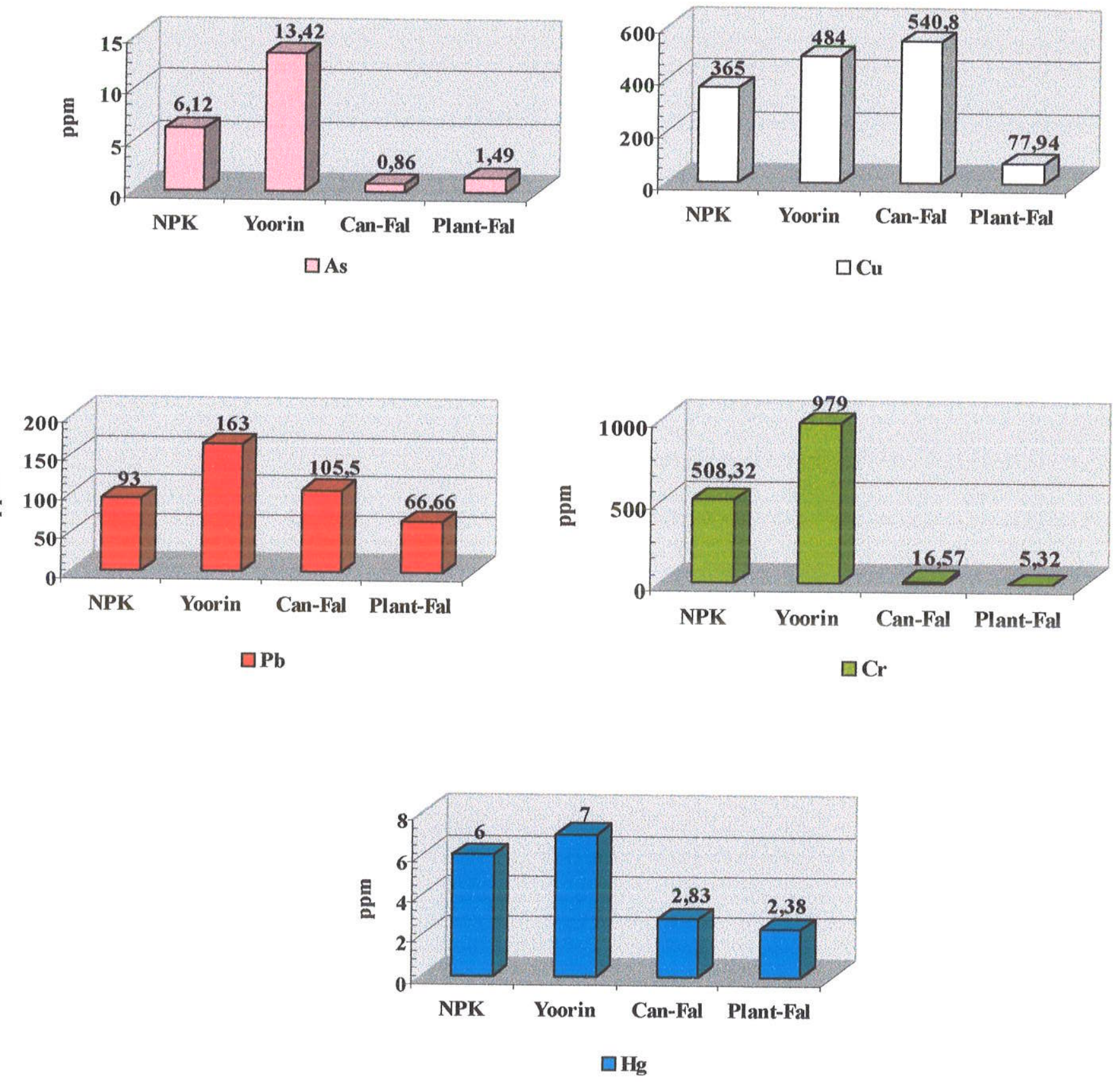

FIGURA 8.3. Resultados analíticos de arsênio e metais pesados dos fertilizantes utilizados na área de estudo 
GABE \& RODELLA (1999) analisaram alguns metais pesados em produtos químicos utilizados na cultura da soja, entre eles, calcário e fertilizantes sintéticos (NPK 4:14:8 e termofosfato Yoorin). Os autores observaram alta concentração de cromo no termofosfato $\left(949 \mathrm{mg} \cdot \mathrm{kg}^{-1}\right)$ e elevada concentração de cobre no NPK $(1,16$ $\left.\mathrm{mg} \cdot \mathrm{kg}^{-1}\right)$.

A agricultura nos moldes atuais não se depara unicamente com a contaminação ambiental por pesticidas mas, de acordo com os resultados apresentados, principalmente, através da adubação sintética.

Atualmente, a utilização de substâncias químicas para o combate de pragas e doenças que afetam a atividade agrícola vem sofrendo reformulações, mas é fato que, metais pesados e semi-metais ainda são encontrados nos agroquímicos.

De acordo com HUTTON \& SYMON (1986), o fertilizante fosfatado é considerado como fonte potencial de arsênio. A concentração de arsênio encontrado em fertilizantes pode variar como decorrência do tipo de depósito de rocha fosfática (ígnea, sedimentar ou biogênica) utilizado na produção do adubo químico, estimando-se em média teor de 7,7 mg. $\mathrm{kg}^{-1}$ de As.

\begin{abstract}
A adubação fosfatada parece constituir a principal fonte de contaminação de arsênio e metais pesados nos solos e água subterrânea do Sítio São Roque. À vista destas determinações, decidiu realizar-se breve estudo da composição química de minérios fosfáticos utilizados como matéria-prima na produção de fertilizantes fosfatados.
\end{abstract}




\section{ROCHA FOSFÁTICA}

Em termos globais, os depósitos sedimentar e ígneo são mais abundantes. A maior parte do fosfato lavrado no mundo provém de fosforitos marinhos. No Brasil, os maciços carbonatíticos são responsáveis pelos maiores depósitos, enquanto que os fosfatos sedimentares formam reservas pequenas e de difícil explotação.

Na década de sessenta, o Brasil tornou-se autosuficiente na produção de matérias-primas fosfáticas para indústria de fertilizante, com desenvolvimento de tecnologia na produção de concentrados apatíticos a partir de minérios de baixo teor, principalmente de origem ígnea ou provenientes do intemperismo dessas rochas.

A rocha fosfática é constituida essencialmente de apatita, com fórmula estrutural $\mathbf{M e}_{10}\left(\mathbf{X O}_{4}\right)_{8} \mathbf{Y}_{2}$ onde $\mathbf{M e}$ pode ser substituído por $\mathrm{Ca}, \mathrm{Pb}, \mathrm{Zn}, \mathrm{Na}, \mathrm{Sr}, \mathrm{Cd}$; $\mathbf{X}$ por $\mathrm{P}, \mathrm{As}, \mathrm{V}, \mathrm{S}, \mathrm{C}$, Si e Y por F, OH, Cl, Br (HARBEN \& BATES, 1990).

A utilização do fosfato como não-fertilizante representa apenas $10 \%$ do consumo mundial em $\mathrm{P}_{2} \mathrm{O}_{5}$. Os $90 \%$ restantes sendo destinados à produção química de componentes fosfatados, destinados à agricultura.

Os depósitos de rocha fosfática sedimentar (fosforitos marinhos) constituem quase $85 \%$ da produção de fosfato comercializada no mundo, enquanto os $15 \%$ restantes provêm de depósitos ígneos. Já os depósitos de guano não se revelam importantes para a produção comercial de fosfato. No Brasil, a maioria dos depósitos fosfatados como Araxá, Catalão, Jacupiranga são depósitos ígneos. Nas jazidas ígneas, a apatita, fosfato de cálcio, é proveniente de complexos alcalinocarbonatíticos. Os minérios fosfáticos, sob ação intempérica, podem enriquecer-se significativamente formando depósitos lateríticos, como os do território brasileiro, africano e australiano (ALCOVER NETO, 1991).

Industrialmente, o termo "rocha fosfática" refere-se tanto ao minério fosfático in situ como ao fosfato beneficiado. Na linha de produção, o concentrado fosfático é transformado em ácido fosfórico ou em fósforo elementar, podendo também ser 
aplicado diretamente nos solos Este procedimento é observado no Brasil e Leste Europeu. A matéria-prima é restrita a um número reduzido de países e em ambientes geológicos específicos (geralmente sedimentares). Efetivamente, dos 250 depósitos de fosfato existentes no mundo, os competitivos encontram-se em três regiões: EUA (1,6 bilhão de toneladas de reservas), Noroeste do Continente Africano (7,5 bilhões de toneladas) e Oriente Médio (1 bilhão de toneladas) (GUEYE, 1998).

O Continente Africano é um dos maiores produtores de rocha fosfática do mundo, sendo responsável por cerca de $25 \%$. O Senegal representa $4,5 \%$ da produção africana de fosfato com ocorrência em Taïba e Lam-Iam. A jazida de Tobene, localiza-se na região fosfática de Taïba.

Neste trabalho para caracterização química de rochas fosfáticas (sedimentar e ígnea), utilizaram-se amostras provenientes de Tobene (fosforito marinho) e Araxá (carbonatito e piroxenito).

\section{Depósito Fosfático de Tobene - Senegal}

Os elementos traços das fluorapatitas de Tobene Ouest, Senegal, pode variar quimicamente segundo a mineralogia presente. Os principais minerais constituintes são crandallita $\left[\mathrm{CaAl}_{3}\left(\mathrm{PO}_{4}\right)_{2}(\mathrm{OH})_{5} . \mathrm{H}_{2} \mathrm{O}\right]$ e francolita $\left[\mathrm{Ca}_{5}\left(\mathrm{PO}_{4}, \mathrm{CO}_{3}\right)_{3}(\mathrm{OH})\right]$. A amostra analisada, neste trabalho, apresenta como principal constituinte mineralógico crandallita (Tobene Ouest), cujos resultados analíticos encontram-se, para melhor visualização, na figura 9.1. 


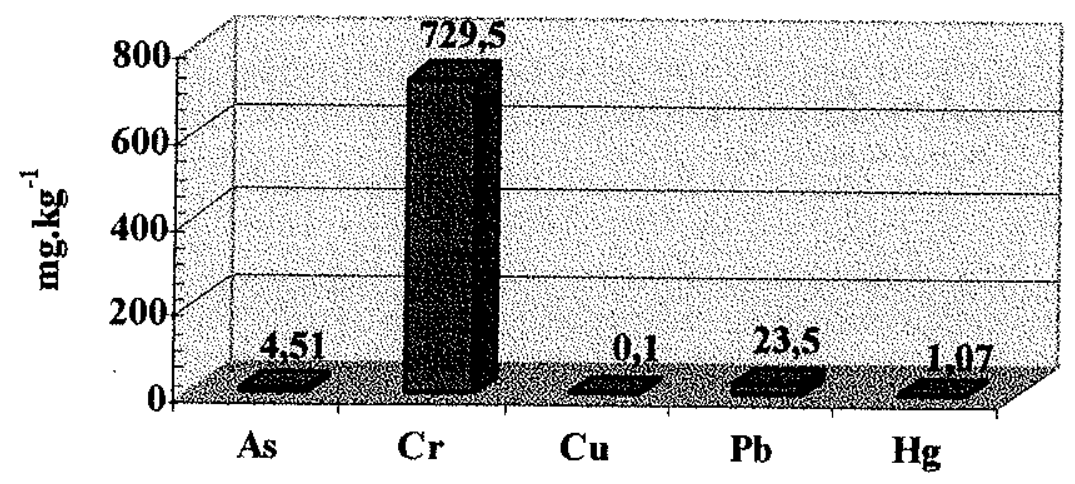

FIGURA 9.1. Resultados analíticos de fosforito marinho de Tobene Ouest, com predomínio do mineral crandallita

$\mathrm{Na}$ figura 9.2, encontra-se o diagrama de colunas com respectivos valores de referência para depósitos sedimentares fornecidos pelas INDUSTRIES CHÍMIQUES DU SÉNÉGAL - ICS (1999).

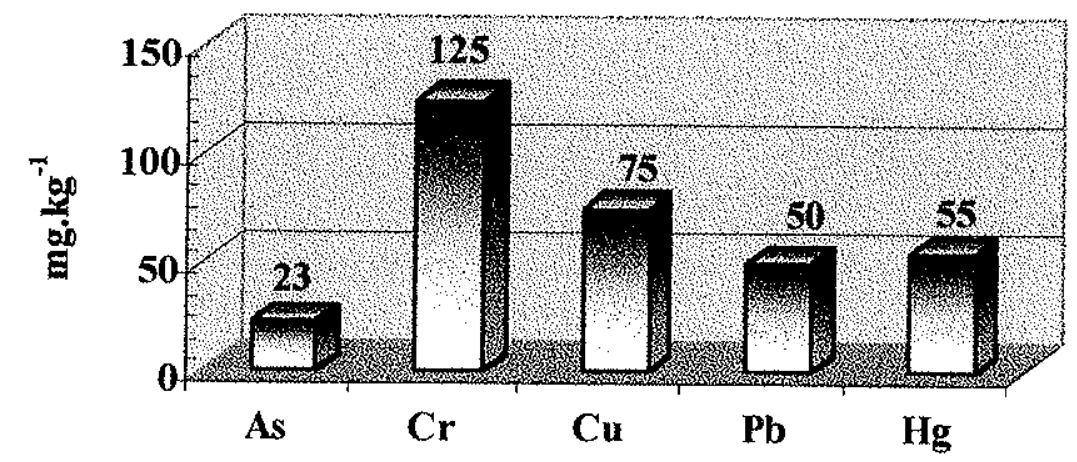

FIGURA 9.2. Resultados analíticos de referência para depósito sedimentar segundo Industries Chímiques du Sénégal (1999) 


\section{Depósitos fosfáticos de Araxá - Brasil}

No Brasil, foram determinados teores de arsênio e metais pesados em minérios fosfáticos de ocorrência em carbonatitos e piroxenitos de Araxá, Minas Gerais. Na figura 9.3, são apresentados os valores médios de arsênio e metais pesados para três determinações. As amostras correspondem a rochas brutas coletadas em afloramentos.

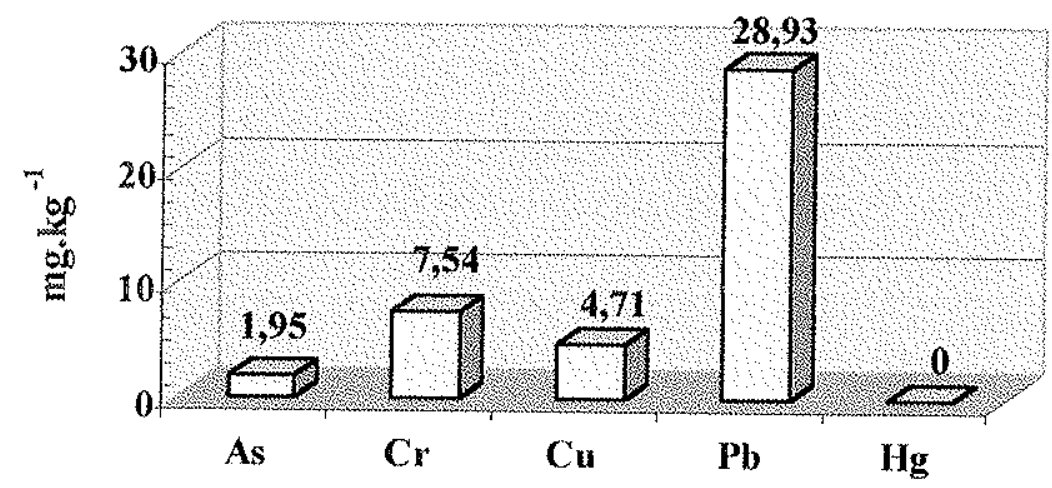

Nota: $\boldsymbol{n . d}$., não detectado (limite de deteç̧ão: $\mathrm{Hg}<0.8 \mu \mathrm{g} . \mathrm{kg}^{-1}$ )

FIGURA 9.3. Resultados analíticos do carbonatito de Araxá, Brasil 
Na figura 9.4 são apresentados os valores médios de arsênio e metais pesados para três determinações.

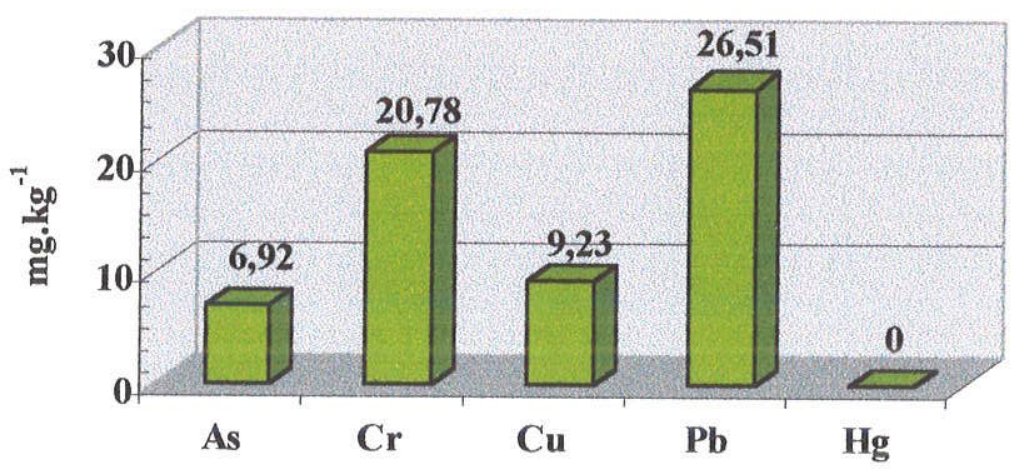

Nota: n.d., não detectado (limite de detecção: $\mathrm{Hg}<0.8 \mu \mathrm{g} \cdot \mathrm{kg}^{-1}$ )

FIGURA 9.4. Resultados analíticos do piroxenito de Araxá, Brasil

GABE (1998) determinou cobre, chumbo e cromo em rocha e concentrado fosfáticos de Tapira, Minas Gerais. O autor observou que o concentrado fosfático apresentou teores mais elevados destes elementos quando comparado à rocha fosfática de origem, concluindo que junto ao processo de concentração de pentóxido de fósforo $\left(\mathrm{P}_{2} \mathrm{O}_{5}\right)$, ocorre também o aumento dos teores de metais pesados.

Como observado, os resultados analíticos revelam que o minério fosfático é um componente importante a ser considerado quanto à presença de metais pesados $\mathrm{e}$ arsênio em fertilizantes fosfatados. Embora tenha sido notado também, diante dos teores determinados no NPK e Yoorin Master, que o produto final pode sofrer alterações, devido principalmente a origem do depósito (matéria-prima), de acréscimos advindos da linha de produção, ou mesmo, mediante processos de concentração de $\mathrm{P}_{2} \mathrm{O}_{5}$. 


\section{FOLHAS E FRUTOS}

O pessegueiro pertence à família das rosáceas, de ciclo perene, adaptado às regiões de clima temperado. No Brasil, a cultura do pêssego teve início nas regiões mais frias e em meados da década de 80 , como resultado de melhoramento genético, introduziram-se variedades de pessegueiro que se tornaram tolerantes ao clima subtropical. As áreas de clima mais quente, das quais faz parte o Estado de São Paulo, começaram então a participar do contexto produtor. $O$ fruto pode ser consumido in natura ou mesmo após processamento industrial.

A ferrugem do pessegueiro é uma doença típica da cultura que se agrava nas condições subtropicais, onde as plantas permanecem nove meses enfolhadas. $O$ controle químico é a forma de prevenção mais utilizada, através da aplicação de fungicidas, uma vez que não existem cultivares comerciais resistentes à doença (MARTINS, 1994). Para aumentar a efíciência operacional, a aplicação de pesticidas está associada a pulverizações com suspensão aquosa dos produtos químicos. Desta forma, foram efetuadas também análises químicas em folhas e frutos (polpa e casca) cujos valores são apresentados na tabela 10.1.

A amostragem foliar foi conduzida tomando por base as folhas extraídas de ramos frutíferos. Os frutos, com maturidade comercial, foram coletados ao acaso e acondicionados em embalagens plásticas esterelizadas.

TABELA 10.1 - Resultados analíticos de frutos (polpa e casca) e folhas do

\begin{tabular}{cccccc}
\multicolumn{7}{c}{ pessegueiro $\left(\mathrm{mg} \cdot \mathrm{kg}^{-1}\right)$} \\
\hline amostra & As & $\mathbf{P b}$ & $\mathbf{C u}$ & $\mathbf{C r}$ & $\mathbf{H g}$ \\
\hline folha & 0,08 & 0,44 & 6,82 & 0,29 & 0,03 \\
casca & n.d & 0,15 & 2,61 & n.d & n.d \\
polpa & n.d & n.d. & 2,33 & n.d & n.d
\end{tabular}

Nota : $n . d$, não detectado (limites de quantificação do método: $0,1 \mathrm{mg} . \mathrm{kg}^{-1}$ para As, Cr e 0,01 $\mathrm{mg} \cdot \mathrm{kg}^{-1}$ para $\mathrm{Hg}$ ) 
Os resultados foram comparados com a legislação em vigor segundo a Portaria n 685 (BRASIL, 1998) quanto aos limites de tolerância para $\mathrm{As}, \mathrm{Pb}, \mathrm{Cu}$, Cr e Hg em alimentos (tabela 10.2).

TABELA 10.2 - Limites máximos de tolerância para contaminantes inorgânicos em alimentos em $\mathrm{mg} \cdot \mathrm{kg}^{-1}$

\begin{tabular}{cc}
\hline elemento & mg.kg $^{-1}$ \\
\hline $\mathbf{A s}$ & 0,50 \\
$\mathbf{C r}$ & 0,10 \\
$\mathbf{C u}$ & 10,00 \\
$\mathbf{P b}$ & 0,50 \\
$\mathbf{H g}$ & 0,01 \\
\hline
\end{tabular}

Segundo ADRIANO (1986), tecidos normais de vegetais contêm teores de cobre entre 5 a $20 \mathrm{mg} \cdot \mathrm{kg}^{-1}$. Concentrações menores a $4 \mathrm{mg} \cdot \mathrm{kg}^{-1}$ são encontradas em plantas defícientes. Já em tecidos foliares teores acima de $20 \mathrm{mg} \cdot \mathrm{kg}^{-1}$ são indicativos de toxicidade.

Os resultados analíticos mostram teores abaixo dos limites de tolerância. Constatou-se, também, que as folhas, por sofrerem tratamento químico mais prolongado (ciclo perene), apresentaram maiores teores de arsênio e metais pesados. 


\section{REMEDIAÇÃO (ARSÊNIO EM ÁGUA)}

Os processos de remediação de arsênio em água são tratados em vasta literatura, com vários métodos e diversas patentes. A atenção dada ao arsênio foi intensificada, principalmente, após incidentes ocorridos em Bangladesh e Oeste de Bengala, onde estima-se que 76 milhões de pessoas ingerem água contendo altas concentrações de arsênio (50 a $3500 \mu \mathrm{g} \cdot \mathrm{L}^{-1}$ ). Trabalhos objetivando a remoção de arsênio em água são em grande número podendo destacar-se os mais recentes: EWALD et al. (2000), KHAIR et al. (2000), CORTOPASSI et al. (2000), KOSMUS (2000), HAMASWAMI et al. (2000), entre outros.

Para NIKOLAIDIS (2000), a remoção de arsenato e arsenito da água, ocorre com a utilização de dispositivo técnico patenteado como AsRT. Os produtos das reaçðes podem formar precipitados como $\mathrm{Fe}(\mathrm{OH})_{3}$ e $\mathrm{FeAsO}_{4}$.

Alguns dos processos de descontaminação de arsênio em água foram testados e avaliados por (HAMANN et al. apud FAUST \& ALY 1999) podendo-se citar o de coagulação-sedimentação-filtração, resinas trocadoras, osmose reversa, alumina ativada e carvão ativado. Os autores elaboraram uma tabela contendo informações gerais quanto a eficiência dos diferentes métodos de remoção de arsênio em água (quadro 11.1). 
QUADRO 11.1 - Informações gerais sobre processos de tratamento de água para remoção de arsênio.

\begin{tabular}{cccccccc}
\hline \multirow{2}{*}{ elemento } & \multirow{2}{*}{ PCSF } & Troca & Iônica (Resinas) & \multicolumn{2}{c}{ Membrana } & \multicolumn{2}{c}{ Adsorção } \\
\hline arsênio (III) & R - B & B - E & cátion & osmose reversa & CA & AA \\
arsênio (V) & B - E & B - E & F & R - B & R - B & B - E \\
\hline
\end{tabular}

Nota: $\mathbf{P C S F}$ - processos de coagulação, sedimentação e filtração; CA - carvão ativado; AA - alumina ativada

F - fraco (0 a 20\% de remoção de As); $\mathbf{R}$ - regular (20 a 60\% de remoção de As);

B - bom (60 a $90 \%$ de remoção de As); $\mathbf{E}$ - excelente (90 a 100\% de remoção de As)

De acordo com os autores, os processos de coagulação-sedimentaçãofiltração não são recomendados para pequenos sistemas de tratamento, como o doméstico. No sistema convencional de tratamento de água os processos de coagulação por sulfato de alumínio $\mathrm{Al}_{2}\left(\mathrm{SO}_{4}\right)_{3}$ e óxido de cálcio $(\mathrm{CaO})$ removem de 20 a $32 \%$ de arsênio total da água, em pH 6,80. Já o uso de cloreto de ferro III $\left(\mathrm{FeCl}_{3}\right)$ remove $90 \%$ de arsênio, em mesmo pH. A adição de oxidantes como $\mathrm{KMnO}_{4}$ ou $\mathrm{Cl}_{2}$ produz retenção da ordem de $98 \%$. A combinação de processos contendo cloro e cloreto de ferro chega a remover aproximadamente $100 \%$ de arsênio da água.

A alumina gama ativada $\left(\gamma-\mathrm{Al}_{2} \mathrm{O}_{3}\right)$ é recomendada para remoção de vários constituíntes inorgânicos, inclusive o arsênio. Esse óxido amorfo é preparado em temperatura na faixa de 300 a $600^{\circ} \mathrm{C}$, a partir da desidratação do hidróxido de alumínio. O processo de adsorção de As (III) e As (V) em alumina ativada, tanto de água doce quanto salina ocorre praticamente em 36 horas. A eficiência na adsorção de arsênio diminui em valores de $\mathrm{pH}$ próxximos a 9,0.

O sistema de troca iônica, por sua vez foi avaliado mediante o uso de resinas trocadoras, mas este mostrou-se também ineficientes em condições de $\mathrm{pH}$ próximas 
a 9,0. Já o carvão ativado granular é citado como bom adsorvente de arsênio, após contato com solução contaminante em 48 horas.

O processo de osmose reversa envolve equipamento técnico especializado sendo recomendado na remoção de muitos outros contaminantes inorgânicos, que não o arsênio. Para As (V) a retenção é de $99 \%$, já para As (III) ocorre variação de 46 a $75 \%$ de acordo com o tipo de membrana utilizada (acetato de celulose, fibra côncava, compósito de filme-delgado, entre outras).

Em contraposição, HATHAWAY \& RUBEL JUNIOR (1993) verificaram que o uso de alumina ativada é indicada somente para pH 5,5 e que a presença de sulfato pode comprometer a eficiência na remoção de arsênio pentavalente da água. Esses mesmos autores relatam que o uso de resina aniônica também foi ineficiente para remoção de As (V) devido a competitividade com sulfato presente na água.

Estes dados tornam-se relevantes visto que, na área de estudo, observam-se altos teores de sulfato na água o que comprometeria o bom desempenho desses processos. 
A filtração doméstica aplicada ao tratamento de água para consumo, é um processo simples com custo bastante diferenciado, variando de acordo com o meio filtrante utilizado, como o carvão ativado, areia, resinas trocadoras, carbonatos de cálcio, magnésio, entre outros. $O$ uso de vela filtrante é de prática preventiva, principalmente, em residências que recebem água diretamente de poços. $O$ meio filtrante amplamente utilizado em sistemas de purificação de água doméstica é o carvão ativado, de origem vegetal, proveniente da casca do coco.

Diante da constatação de arsênio na água do sítio São Roque, uma série experimental foi realizada, com objetivo de remover esse elemento da água, mediante utilização de material adsorvente de baixo custo. A talha de terracota, normalmente utilizada em zonas rurais foi selecionada para os estudos de remediação.

Foram testados vários materiais como adsorventes para arsênio, entre eles: $\boldsymbol{l} \tilde{\boldsymbol{a}}$ de aço, ferro em pó, zinco e carvão ativado. A lã de aço foi testada devido seu baixo custo e facilidade de aquisição em estabelecimentos comerciais. O ferro em pó foi escolhido por seu grau de pureza e sua reconhecida aptidão em adsorver ânions. O pó de ferro é proveniente da reciclagem de aço carbono e apresenta, em sua composição química, apenas $0,01 \%$ de carbono. O zinco foi escolhido por ser mais eletropositivo quando comparado ao ferro. O carvão ativado foi testado, uma vez que é amplamente utilizado em dispositivos de purificação.

O carvão ativado granular apresenta aplicações específicas no controle da coloração, remoção de odor e substâncias orgânicas da água. A capacidade de adsorção do carvão ativado deve-se a presença de poros e à superfície específica ativa. A carga superficial do carvão ativado é influenciada pelo pH do meio (AMERICAN WATERS WORKS ASSOCIATION, 1992).

A escolha do material como meio filtrante acha-se na dependência, não só da capacidade em adsorver ânions, mas também do seu comportamento diante do pH. É certo que os materiais ferrosos são mais suscetíveis à corrosão em meio ácido, como 
também, em meio contendo cloreto (RODRIGUES, 1997). Na área de estudo, cabe lembrar que a água dos poços é, em geral, ligeiramente ácida com presença acentuada de cloreto. Em sua condição natural, a água produz corrosão acentuada em materiais à base de ferro, levando à oxidação dos mesmos. Nos experimentos contendo lã de aço e ferro em pó, verificou-se o ataque corrosivo dos materiais, evidenciado diante da mudança na coloração da água devido a presença de óxidos e hidróxidos de ferro, segundo reações químicas:

$$
\begin{aligned}
& 2 \mathrm{Fe}_{(\mathrm{s})}+4 \mathrm{OH}_{(\mathrm{aq})}+1 / 2 \mathrm{O}_{2(\mathrm{~g})} \rightarrow 2 \mathrm{FeOOH}_{(\mathrm{s})}+\mathrm{H}_{2} \mathrm{O}_{(\mathrm{l})} \\
& 8 \mathrm{FeOOH}_{(\mathrm{s})}+\mathrm{Fe}^{2+}{ }_{(\mathrm{aq})}+2 \mathrm{e}^{-} \rightarrow 3 \mathrm{Fe}_{3} \mathrm{O}_{4(\mathrm{~s})}+4 \mathrm{H}_{2} \mathrm{O}_{(\mathrm{l})}
\end{aligned}
$$

A seguir, na figura 11.1 são apresentadas as micrografias obtidas por microscopia eletrônica de varredura dos materiais testados na retenção do arsênio: $\mathbf{a}$. lã de aço com morfologia de filamentos contínuos e achatados; b. ferro apresenta-se na forma de agrupamento de partículas irregulares sinterizada; c. o zinco granular como agrupamento partículas irregulares a esféricas; d. carvão ativado como partícula longitudinal, com poros de forma e tamanho variáveis. 

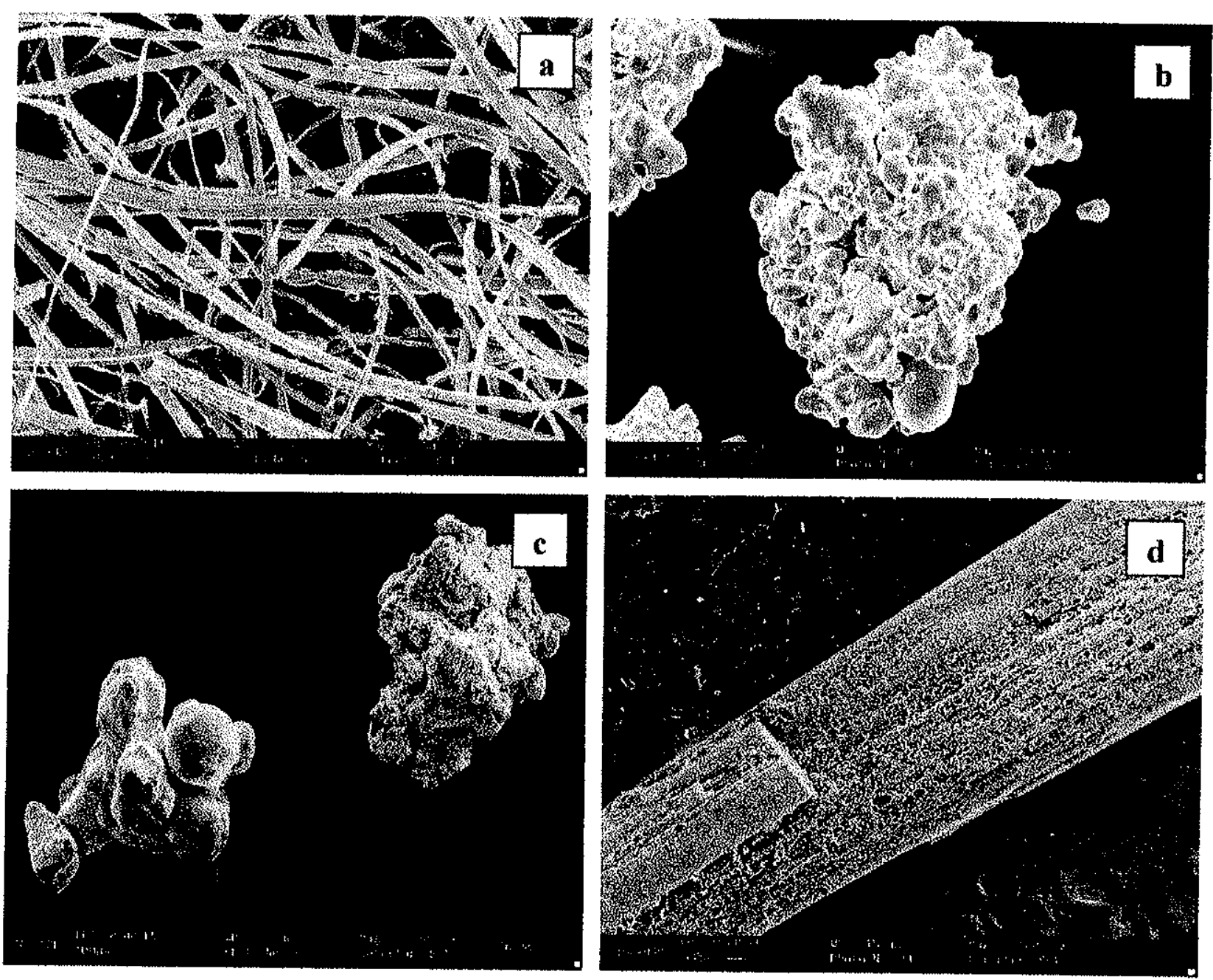

FIGURA 11.1. Micrografia eletrônica de varredura dos materiais utilizados na retenção de arsênio: a. lã de aço; b. ferro em pó; c. zinco granular e d. carvão ativado 
A retenção do arsênio foi testada experimentalmente com lã de aço, ferro em pó, zinco granular e carvão ativado.

Efetuaram-se experimentos a temperatura ambiente utilizando, inicialmente, soluções de arsênio com concentrações de 0,$5 ; 2,5 ; 5,0 ; 7,5$ e $10 \mathrm{mg} . \mathrm{L}^{-1}$, tomando-se como referência os experimentos realizados por BOYER \& GALLY (1998).

As soluções de arsênio utilizadas nos experientos foram preparadas a partir de $\mathrm{As}_{2} \mathrm{O}_{3}$ dissolvido em $\mathrm{NaOH}$ e o pH do meio ajustado a 7,0, pela adição de $\mathrm{HCl}$. $\mathrm{O}$ trióxido de arsênio é moderadamente solúvel em água, entretanto, dissolve-se facilmente em meio alcalino, produzindo o arsenito, $\mathrm{AsO}_{2}{ }^{-}$(KING, 1995).

A massa de cada material adsorvente foi estabelecida em $1 \mathrm{~g}$, com precisão até a quarta decimal. As misturas foram mantidas em repouso e para controle foram lidos $\mathrm{pH}$ iniciais e finais. Os valores médios de equilíbrio foram de 6,6 para materiais ferrosos, 6,4 para o zinco e 6,8 para carvão ativado.

As soluções de partida, após 30 minutos de contato com os diferentes materiais foram filtradas e submetidas a análise química. $\mathrm{O}$ tempo de contato foi estabelecido em 30 minutos, uma vez que a retenção do arsênio ocorre nos primeiros minutos de contato.

As projeções dos teores de arsênio retidos pelos diferentes materiais utilizados em função das concentrações de partida encontram-se na figura 11.2. 

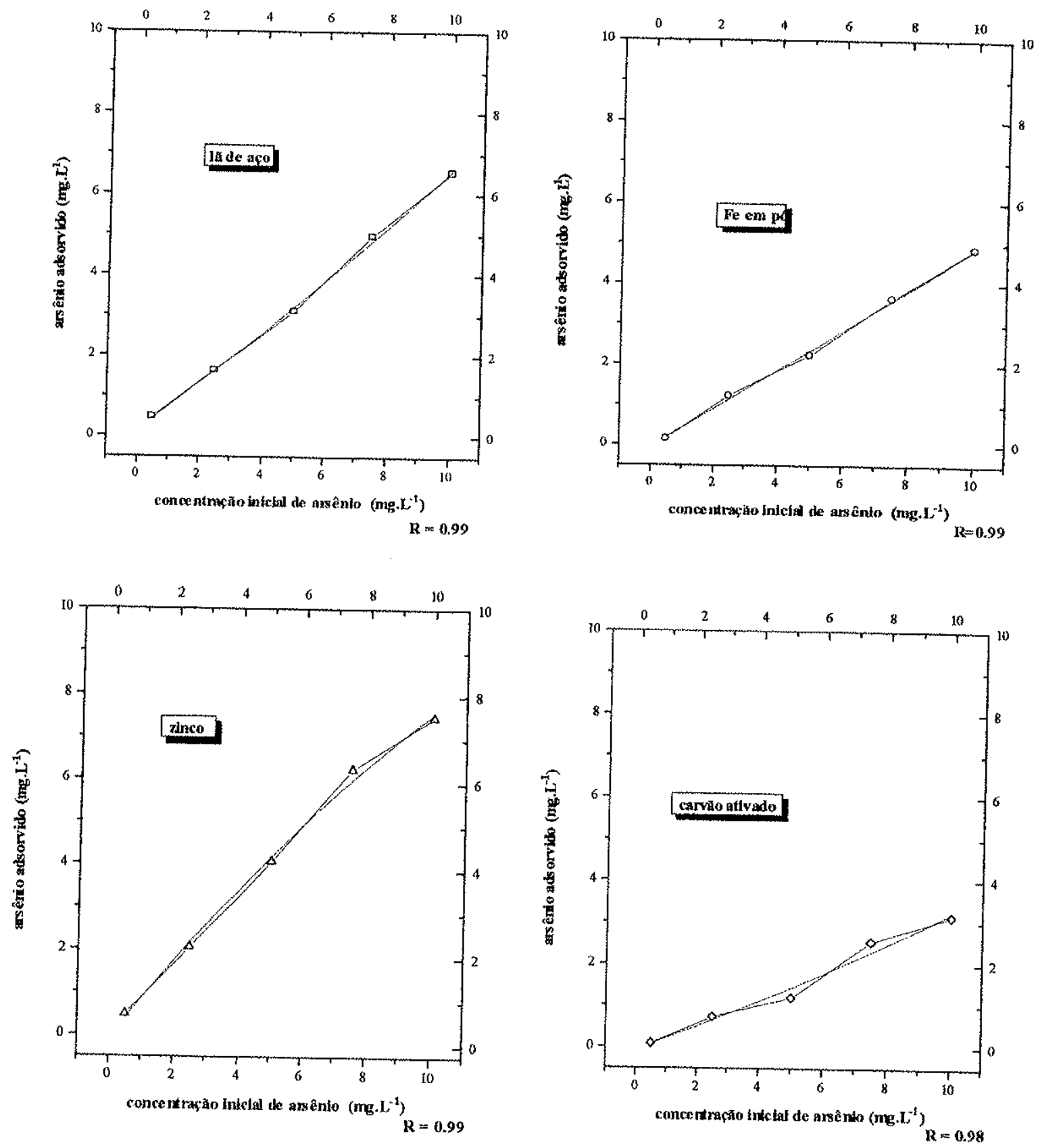

FIGURA 11.2. Projeção gráfica dos teores de arsênio adsorvidos em lã de aço, ferro em pó, zinco granulado e carvão ativo. 
Constatou-se que houve retenção de arsênio pelos materiais utilizados. O aumento na dosagem resultou no acréscimo de sorção embora, em diferentes graus de intensidade: zinco granular > lã de aço > ferro em pó > carvão ativado.

A retenção de arsênio pelo zinco e lã de aço foi notadamente mais eficiente em relação aos outros materiais, principalmente, em concentração de $0,5 \mathrm{mg} \cdot \mathrm{L}^{\mathrm{l}}$. O zinco granular reteve cerca de $96 \%$ de arsênio, na forma de arsenito e a lã de aço $92 \%$. Os menores valores de retenção de arsênio foram observados para o ferro em pó com $32 \%$ e carvão ativado com $18 \%$.

O comportamento desses materiais quanto a remoção de arsênio da solução foi significativo diante da variação da concentração, levando-se em conta o tempo de contato pré-estabelecido em 30 minutos.

Essa série experimental foi repetida com ânion arsenato, observando-se o mesmo comportamento qundo comparado ao arsenito, isto é, a retenção gradativa de arsênio, com maior eficiência também para zinco e lã de aço.

Os resultados experimentais permitiram, portanto, a exclusão do ferro em pó em razão de seu comportamento pouco satisfatório quando comparado a lã de aço. $O$ carvão ativado mostrou-se aceitável, uma vez que somam-se às suas propriedades, a capacidade de sorver arsênio.

Uma das preocupações com a utilização do zinco e lã de aço como meio filtrantes, apesar dos resultados promissores, passou a ser a liberação na água de constituintes indesejáveis como zinco e óxidos e hidróxidos de ferro. 
Novos ensaios foram realizados, agora, entretanto, frente as condições observadas na área de estudo, ou seja, foi tomada como referência a maior concentração de arsênio determinada na água dos poços $\left(0,17 \mathrm{mg} . \mathrm{L}^{-1}\right)$.

Nesta série experimental foram testados apenas zinco e lã de aço. A solução de partida contendo $0,25 \mathrm{mg} . \mathrm{L}^{-1}$ de arsênio foi adicionada em um grama de zinco granular e de lã de aço. Após intervalos de tempo pré-estabelecidos em 1, 7, 15 e 30 dias, as soluções foram encaminhadas para determinação química de Fe, Zn e As. Os ensaios foram acompanhados de brancos. Os valores determinados para de ferro e zinco foram projetados na figura 11.3, já o arsênio não foi detectado em solução. No sistema contendo lã de aço/As o pH ficou em média de 6,6, com Eh próximo de $+0,11 \mathrm{~V}$ e para o sistema contendo zinco/As, o pH foi de 6,4 com Eh $+0,38 \mathrm{~V}$.

Os diagramas $\mathrm{pH}=\mathrm{f}(\mathrm{Eh})($ BROOKINS, 1988) comprovam, diante destas condições, a estabilidade de $\mathrm{Fe}^{2+}$ e $\mathrm{Zn}^{2+}$ em solução. 

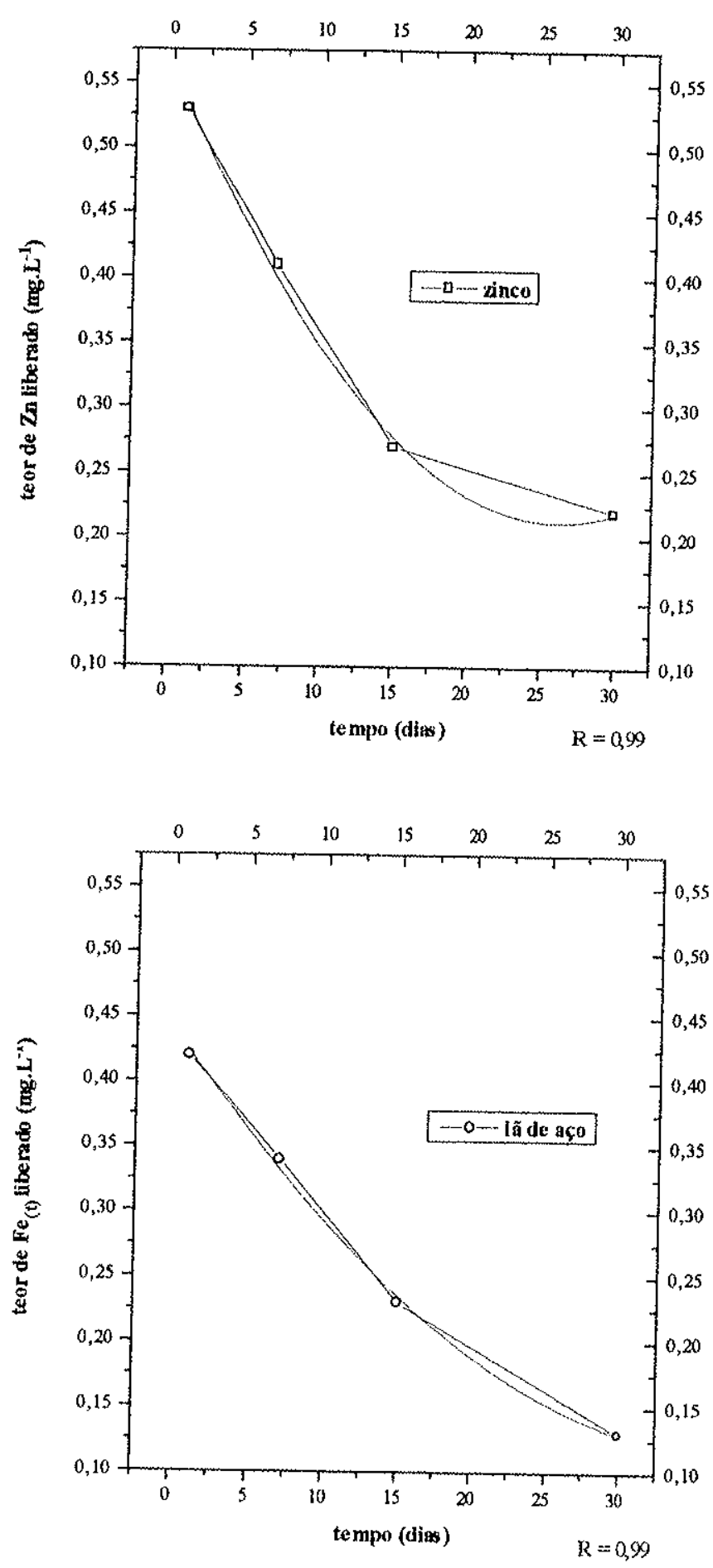

FIGURA 11.3. Teores de ferro e zinco em solução, após $1,7,15$ e 30 dias de contato entre lã de aço e zinco granular com $0,25 \mathrm{mg} . \mathrm{L}^{-1}$ de As 
No primeiro dia de contato, tanto lã de aço quanto zinco, removeram todo arsênio da solução.

A liberação dos íns metálicos de ferro e zinco diminuiram em função do tempo, o teor de $\mathrm{Zn}$ em solução foi superior ao do ferro cerca de $60 \%$.

Finalmente, foram realizados experimentos em talha de terracota com velas de filtro de cerâmica, segundo modelo apresentado na figura 11.4. Em cada vela de filtro acondicionou-se $1 \mathrm{~g}$ de lã de aço e a mesma massa de zinco, sem a presença de carvão ativado. Os ensaios de filtração receberam concentração de $0,25 \mathrm{mg} \cdot \mathrm{L}^{-1}$ de arsênio.

A vazão média obtida foi de $80 \mathrm{~mL} \cdot \mathrm{min}^{-1} \mathrm{e}$ os primeiros mililitros mostraramse isentos de arsênio para limite de deteç̧ão de $0,03 \mu \mathrm{g} \cdot \mathrm{L}^{-1}$. A presença de ferro não foi detectada na água filtrada para um limite de $0,14 \mathrm{mg} \cdot \mathrm{L}^{-1}$.

A vela de cerâmica atuou perfeitamente como barreira impedindo a passagem de óxidos e hidróxidos de ferro para solução. $\mathrm{O}$ mesmo comportamento não foi observado para o zinco que continuou presente na água filtrada apresentando um valor médio de $3,8 \mathrm{mg} . \mathrm{L}^{-1}$.

A WORLD HEALTH ORGANIZATION (1984) estabeleceu, em relação aos aspectos estéticos da água (cor, sabor e cheiro), valores de limites de tolerância para Fe de $0,3 \mathrm{mg} \cdot \mathrm{L}^{-1}$ e para o $\mathrm{Zn}$ de $5,0 \mathrm{mg} \cdot \mathrm{L}^{-1}$.

O ferro é essencial ao organismo humano, indispensável à constituição da hemoglobina, da mioglobina e de enzimas. O ferro armazena-se no organismo sob a forma de ferritina e hemossiderina, cuja carência causa anemia do tipo microcítica hipocrômica. Para adultos, recomenda-se a ingestão diária de ferro de 3 a $5 \mathrm{mg}$ (MACRAE et al. 1993). 
A dosagem diária de zinco para recém-nascidos é de $1,2 \mathrm{mg} . \mathrm{L}^{-1}$, já para adultos de 2,2 mg. $\mathrm{L}^{-1}$. Mulheres no período de lactação requerem diariamente 5,4 mg. $L^{-1}$ de zinco. A principal rota de expulsão do $\mathrm{Zn}$ ocorre por meio da excreção renal. Adultos em estado crônico de ingestão, da ordem de 10 a $15 \mathrm{mg}$ ao dia, podem excretar diariamente aproximadamente $500 \mu \mathrm{g} . \mathrm{L}^{-1}$ de zinco através da urina (MACRAE et al. 1993).

Levando-se em conta essas considerações e os resultados obtidos, inferiu-se que o zinco metálico não é indicado para sistemas de purificação de água, em virtude de teores significativos encontrados nas soluções, além de induzir uma variação ácida no sistema.

O ferro, no entanto, graças ao baixo custo somado a sua capacidade de retenção do arsênio, foi selecionado como material viável e adequado a minimizar o arsênio da água de consumo.

A proposta inicial quanto a utilização da lã de aço esteve atrelada ao compromisso custo-beneficio, de modo que assegurasse a viabilidade de seu emprego. A mudança na coloração da água, devido a presença de óxidos e hidróxidos de ferro foi plenamente controlada diante do uso da vela de cerâmica microporosa. A utilização de talhas de terracota contendo, como meio filtrante, carvão ativado e lã de aço pode ser recomendada em áreas onde a contaminação de arsênio faz-se presente, principalmente, em regiões com população de baixa renda, uma vez que o custo da lã de aço, no varejo, é irrisório.

Esta medida simples poderá ser efetuada pelos próprios usuários, necessitando apenas acondicionar pequena massa de lã de aço no interior da vela de filtro, sugerindo, também que a vedação da vela de filtro seja efetuada por rosqueamento, para facilitar a operação. 
Como sugestão, tem-se a vela filtrante (figura 11.4) constituida por carvão ativado e lã de aço; o carvão ativado, por adsorver cloro, turbidez, odor e sabor desagradáveis da água, além de contribuir também na adsorção de arsênio; já a lã de aço deve ser utilizada como meio filtrante para purificação de arsênio da água.
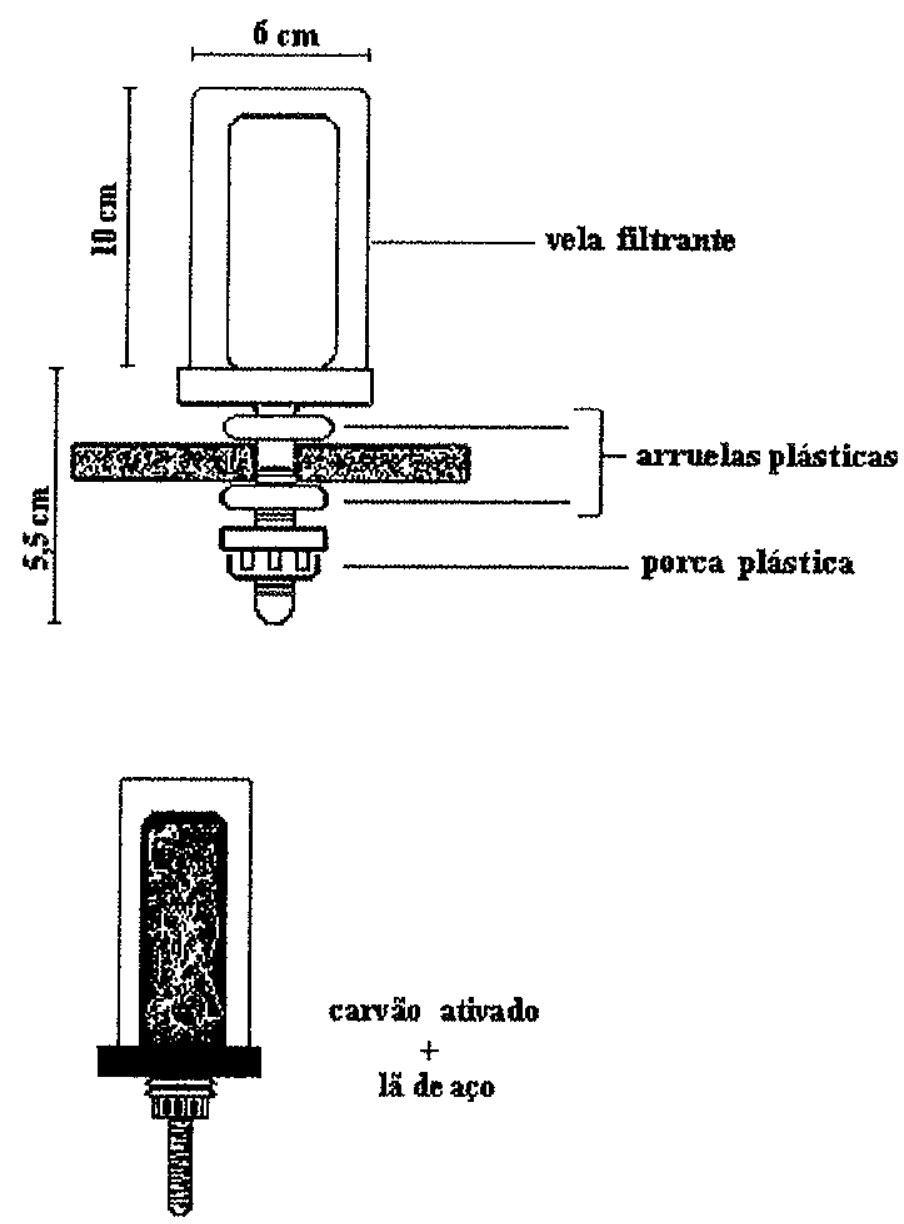

FIGURA 11. 4. Representação esquemática da vela de filttro utilizada em filtros domésticos, desenho técnico fornecido pela Cerâmica Stéfani S.A. 
Este trabalho apresentou como proposta final, o desenvolvimento de método alternativo de purificação de arsênio da água. As reações possíveis são apresentadas e carecem de um estudo minuncioso quanto a investigação dos mecanismos envolvidos. As reações citadas, no entanto, não são únicas e a medida que prosseguem, desencadeiam uma série de outros processos.

A complexidade química das reações que envolvem os compostos de arsênio não permite que se utilize um determinado reagente para sua fixação. Assim, sua eliminação da água de consumo baseou-se no uso de substâncias inorgânicas que propiciassem o fenômeno de adsorção, co-precipitação e precipitação de compostos de arsênio.

Exploraram-se os fenômenos óxi-redução para liberação de íons metálicos com reações químicas secundárias que envolvam arsênio. Os compostos mais simples de arsênio são arsina $\left(\mathrm{AsH}_{3}\right)$, arsenitos $\left(\mathrm{H}_{3} \mathrm{AsO}_{3}, \mathrm{H}_{2} \mathrm{AsO}_{3}{ }^{-}, \mathrm{HAsO}_{3}{ }^{2-}, \mathrm{AsO}_{3}{ }^{3-}\right.$ ) e arsenatos $\left(\mathrm{H}_{2} \mathrm{AsO}_{4}{ }^{-}, \mathrm{H}_{3} \mathrm{AsO}_{4}, \mathrm{HAsO}_{4}{ }^{2-}, \mathrm{AsO}_{4}{ }^{3{ }^{3}}\right)$.

Os potenciais de óxido-redução dos compostos de interesse são apresentados a seguir:

$$
\begin{array}{ll}
\mathrm{H}_{3} \mathrm{AsO}_{4(\mathrm{aq})}+2 \mathrm{H}^{+}{ }_{(\mathrm{aq})}+2 \mathrm{e}^{-} \rightleftarrows \mathrm{HAsO}_{2(\mathrm{aq})}+2 \mathrm{H}_{2} \mathrm{O}_{(\mathrm{l})} & (+0,56 \mathrm{~V}) \\
\mathrm{AsO}_{4}{ }^{3-}{ }_{(\mathrm{aq})}+2 \mathrm{H}_{2} \mathrm{O}_{(\mathrm{l})}+2 \mathrm{e}^{-} \rightleftarrows \mathrm{AsO}_{2}^{-}{ }_{(\mathrm{aq})}+4 \mathrm{OH}_{(\mathrm{aq})}^{-} & (-0,71 \mathrm{~V}) \\
2 \mathrm{Fe}^{2+}{ }_{(\mathrm{aq})}+2 \mathrm{e}^{-} \rightleftarrows 2 \mathrm{Fe}_{(\mathrm{s})} & (-0,44 \mathrm{~V}) \\
\mathrm{Fe}^{3+}{ }_{(\mathrm{aq})}+\mathrm{e}^{-} \longleftrightarrow \mathrm{Fe}^{2+}{ }_{(\mathrm{aq})} & (+0,77 \mathrm{~V})
\end{array}
$$

Ao se introduzir fios de ferro em água contendo arsênio inorgânico em $\mathrm{pH}$ próximo a 7, verificou-se total desaparecimento do arsênio e íns ferro da solução. Dada a complexidade das diferentes formas, tanto do ferro quanto do arsênio que podem surgir no sistema, torna-se extremamente difícil que se prescrevam os 
mecanismos de suas reações químicas. Algumas possibilidades, no entanto, poderão ser apresentadas a partir das propriedades químicas das diferentes espécies.

O ferro metálico pode sofrer oxidação em ambiente aquoso, aeróbio ou na presença de elementos com potencial de óxi-redução superior $\mathrm{a}-0,44 \mathrm{~V}$, com redução de arsenatos a arsenitos. A liberação de ions para solução e a velocidade com que isso ocorre é função da presença de elementos que reagem com $\mathrm{Fe}_{3} \mathrm{Fe}^{2+} \mathrm{e}$ $\mathrm{Fe}^{3+}$, deslocando o equilíbrio no sentido da formação de uma outra espécie.

A oxidação do metal leva sempre à presença de cargas positivas expostas em sua superfície e favorece condições para adsorção de partículas carregadas negativamente como, por exemplo, $\mathrm{AsO}_{4}{ }^{3-}, \mathrm{AsO}_{2}{ }^{-}$, etc. Os compostos de arsênio nos processos de oxidação do ferro, tendem a se apresentar na forma reduzida :

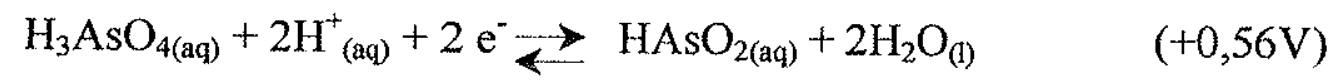

Quando em solução, o ferro pode sofrer hidrólise produzindo localmente diminuição do pH. Lembrando que, em condições de Eh próximo a 0,80 e pH 2,5 tem-se $\mathrm{Fe}^{3+}$ como na reação:

$$
\begin{gathered}
\mathrm{Fe}^{3+}+\mathrm{H}_{2} \mathrm{O} \rightleftarrows[\mathrm{Fe}(\mathrm{OH})]^{2+}+\mathrm{H}^{+} \\
{[\mathrm{Fe}(\mathrm{OH})]^{2+}+\mathrm{H}_{2} \mathrm{O}} \\
\longleftrightarrow\left[\mathrm{Fe}(\mathrm{OH})_{2}\right]^{+}+\mathrm{H}^{+} \\
{\left[\mathrm{Fe}(\mathrm{OH})_{2}\right]^{+}+\mathrm{H}_{2} \mathrm{O} \longleftrightarrow \mathrm{Fe}(\mathrm{OH})_{3(\mathrm{~s})}}
\end{gathered}
$$

O hidróxido de ferro (III) pouco solúvel propicia, em sua forma coloidal o fenômeno de adsorção que poderá precipitar, dependendo da concentração de sais e do $\mathrm{pH}$ do meio. A precipitação do $\mathrm{Fe}(\mathrm{OH})_{3}$ além de facilitar a sorção aniônica, também pode apresentar íons estranhos a sua composição devido a co-precipitação. 
Na superfície do metal pode ocorrer ainda, adsorção de arsênio com formação de compostos pouco solúveis. Esses mecanismos podem se estender também para outros metais como, por exemplo, o zinco. Quando se mantiveram ferro e zinco submetidos por algumas horas imersos em solução $40 \mathrm{mg} \cdot \mathrm{L}^{-1}$ de arsenato, constatouse formação de produto de cor branca, amorfo (conforme exame em difratometria de raios $\mathrm{X}$ ), revestindo os metais. Tratando-se, certamente de compostos pouco solúveis de arsênio e ferro e arsênio e zinco, com fórmulas químicas complexas não estequiométricas. 


\section{CONCLUSÕES}

A área de estudo é constituída por Latossolo Vermelho-Amarelo (Estação Experimental III) e Cambissolo Háplico (Estações Experimentais I e II). Os solos refletem a composição mineralógica das rochas originais, com texturas variando de franco argilo arenoso a franco arenoso. Neste local, identifica-se aqüifero de manto de alteração, de natureza livre.

$\mathrm{Na}$ área encontram-se, principalmente, culturas de pêssego distribuídas ao longo da encosta frontal, com emprego de produtos contendo constituíntes tóxicos como pesticidas, utilizados para minimizar a incidência de pragas e doenças e fertilizantes sintéticos, usados para aumentar a produtividade dos solos. Esses produtos, amostrados em campo, quando encaminhados para exames químicos, revelaram a presença de arsênio, cromo, cobre, chumbo e mercúrio em todos pesticidas, indicando que estes apresentam certa parcela na contribuição desses elementos ao meio.

A adubação fosfatada, por sua vez, constitui-se a principal fonte de contaminação de arsênio e metais pesados $(\mathrm{Cr}, \mathrm{Cu}, \mathrm{Pb}$ e $\mathrm{Hg}$ ) nos solos e, conseqüentemente, na água subterrânea. Isso ocorre em virtude da alta dosagem empregada anualmente e diante da aplicação direta no solo. O fornecimento de macronutrientes nos solos, acarreta também na adição indireta de metais pesados e semi-metais nos solos.

É importante ressaltar que, a presença de elementos traço nos fertilizantes fosfatados, é decorrente da origem da rocha fosfática utilizada na produção do adubo químico, isto é, o minério fosfático torna-se um componente importante a ser considerado quanto a existência de metais pesados e arsênio em fertilizantes fosfatados. Observou-se também que o produto final pode sofrer alterações, em virtude de acréscimos advindos da linha de produção. 
A análise dos resultados pluviométricos dos últimos dez anos, revela maior freqüência de chuvas para os meses que caracterizam o verão. As águas de chuva analisadas, para todos os periodos, apresentaram caráter ligeiramente ácido. $\mathrm{O}$ índice de acidez em julho deve-se a presença de compostos derivados de enxofre, introduzido pela aplicação por aspersão da calda sulfocálcica, que se reflete também no potencial de oxi-redução, imprimindo-lhe valor negativo. Nesse periodo, foi constatado que por ocasião da pulverização da calda sulfocálcica criou-se, nos solos das Estações II e III, ambiente redutor na camada superficial do solo.

A água superficial correspondente ao córrego da Toca e nascente São Roque, apresentaram baixos teores de arsênio e metais pesados, em virtude do arraste aéreo, por ocasião do tratamento químico nos pomares. A contaminação da água constatada nos reservatórios deve-se à limpeza de equipamentos e maquinários utilizados na lavoura.

O término da estação chuvosa (abril), coincidente com o fim da adubação de cobertura e início do calendário de aplicação de agroquímicos, explicam os valores elevados de condutividade elétrica e de sólidos totais dissolvidos na água da zona saturada . O teor de nitrato na água da zona saturada foi elevado estando associado à aplicação de NPK e esterco de galinha; da mesma forma, a concentração elevada de cloreto e sulfato é devido à adubação de cobertura.

$\mathrm{Na}$ zona não-saturada, constatou-se que é bastante significativa a contaminação por ocasião dos tratamentos químicos, condição esta pouco pronunciada na Estação Experimental I. Nas Estações II e III, em todos os períodos, tem-se associado ao arsênio, a presença de cobre e, em menores quantidades de chumbo e cromo. Dada a semelhança química, é provável também a presença de fósforo, sob a forma de fosfato, associado a esses cátions.

$\mathrm{Na}$ Estação de Referência, o mercúrio foi detectado apenas no horizonte superficial, provavelmente em razão da contaminação, via aérea, durante os tratamentos das culturas com agroquímicos nas quadras de plantio. Nas demais 
Estações foram observados teores mais elevados nos níveis superficiais do solo, mostrando baixa mobilidade e acentuada afinidade (adsorção) do $\mathrm{Hg}^{2+}$ pela matéria orgânica e argilominerais dos solos associados. O mercúrio em nenhum momento esteve presente nas águas atmosférica, superficial e subterrânea.

As concentrações de cromo, chumbo e cobre nos solos são provenientes dos pesticidas e fertilizantes fosfatados, uma vez que é pouco significativa a contribuição das rochas parentais. Na Estação Experimental III, a partir do nível d'água, constatou-se que arsênio e cobre chegam a zero; o cromo e chumbo permaneceram constantes. Excetuando-se o mercúrio, chumbo e cromo, que não atingiram o aqüífero, arsênio e cobre, provenientes principalmente da adubação fosfatada, migraram para zona saturada.

Os teores de $\mathrm{Pb}$ foram maiores nos horizontes superficiais das três Estações, diminuindo de forma acentuada até profundidade próxima de $150 \mathrm{~cm}$, provavelmente adsorvido pelas raízes, matéria orgânica e constituíntes minerais do solo. A retenção de chumbo pode ocorrer, também, devido processo de adsorção junto ao recobrimento de óxidos hidratados de ferro sobre grãos de quartzo, o que impede sua mobilidade. Não foi observado teor significativo de chumbo na água de chuva.

As presenças de fósforo e matéria orgânica nos solos podem ser apontadas como principais fatores de retenção do cromo, reduzindo consideravelmente sua migração até o aqüífero.

Na Estação Experimental III, diante dos resultados analíticos, observa-se maior concentração de fósforo disponivel quando comparada à matéria orgânica, levando a crer que o chumbo, além de ser retido pela matéria orgânica, também pode formar composto fosfatado, estável, insolúvel, resultante da reação:

$$
\mathrm{Pb}^{2+}{ }_{(\mathrm{aq})}+\mathrm{PO}_{4}^{3-}{ }_{(\mathrm{aq})} \longleftrightarrow \mathrm{Pb}_{3}\left(\mathrm{PO}_{4}\right)_{2(\mathrm{~s})}
$$


Como o quimismo do arsênio é similar ao do fósforo, também é de se esperar, no meio natural, a formação de arsenato de chumbo $\left[\mathrm{Pb}_{3}\left(\mathrm{AsO}_{4}\right)_{2}\right]$ :

$$
\mathrm{Pb}^{2+}{ }_{(\mathrm{aq})}+\mathrm{AsO}_{4}{ }^{3-}{ }_{(\mathrm{aq})} \longleftrightarrow \mathrm{Pb}_{3}\left(\mathrm{AsO}_{4}\right)_{2(\mathrm{~s})}
$$

O traçado migratório de arsênio e cobre até a zona saturada deve-se, não só, pelas características do meio (textura do solo e à natureza do aqüífero), mas diante da competitividade aniônica entre $\mathrm{HPO}_{4}{ }^{2-} \mathrm{e}_{2} \mathrm{AsO}_{4}{ }^{-}$, onde o quimismo do arsenato torna-se mais atuante e móvel diante da alta concentração de fósforo no solo. $\mathrm{O}$ efeito da pulverização da calda sulfocálcica favoreceu a formação de ambiente redutor, na camada superficial do solo, levando ao predomínio de arsenito $\left(\mathrm{H}_{3} \mathrm{AsO}_{3}\right)$ sobre arsenato $\left(\mathrm{H}_{2} \mathrm{AsO}_{4}{ }^{\circ}\right)$ que, sendo mais móvel, levou ao aumento da concentração do arsênio em solução, com possibilidades de atingir a zona saturada. Em geral, o $\mathrm{Cu}^{2+}$ forma com arsenito, sais insolúveis $\left[\mathrm{CuHAsO}_{3}, \mathrm{Cu}_{3}\left(\mathrm{AsO}_{3}\right)_{2} \cdot \mathrm{H}_{2} \mathrm{O}\right]$ que provavelmente foram liberados quando houve a transformação em arsenato solúvel. $O$ arsenito, em aproximadamente quatro dias, converte-se em arsenato.

Nos solos, a condição reinante de alta concentração localizada de fosfato pode desestabilizar ligações entre íons metálicos e minerais, favorecendo a mobilização de arsênio e metais até o aqüifero, principalmente àqueles de natureza livre e pouco profundos. $O$ arsênio também pode associar-se aos compostos orgânicos. A complexação de arsênio por matéria orgânica impede que seja sorvido ou coprecipitado por fases sólidas orgânicas ou inorgânicas, favorecendo sua mobilidade para o meio aquático.

No Brasil, decorridos mais de dez anos desde a aprovação da "Lei dos Agrotóxicos", marco da implantação prática do receituário agronômico, é patente sua ineficácia como intrumento de apoio ao controle de elementos tóxicos ao meio, uma vez que, como foi evideciado neste trabalho, os adubos químicos e pesticidas, são fontes potenciais de metais pesados e arsênio em solos de uso agrícola. 
Diante das análises de fósforo disponivel, com teores que chegam a 500 $\mathrm{mg} \cdot \mathrm{kg}^{-1} \mathrm{em}$ profundidade de até $30 \mathrm{~cm}$ do solo, infere-se que devem ser adotadas práticas que visem reaproveitamento do fósforo pelo vegetal, evitando assim, adições incessantes de adubos fosfatados. No solo, o emprego de fertilizantes são geralmente dispendiosos, podendo atuar como poluentes ambientais, uma vez que, a adição de macronutrientes pressupõe também no acréscimo de constituíntes tóxicos como arsênio, cromo, chumbo, mercúrio entre outros.

Em relação à entrada de arsênio no solo através da aplicação de calda sulfocálcica, deve-se optar por produtos credenciados, que fornecem Certificado de Qualidade do Enxofre, o que reduz drasticamente o teor de arsênio no produto.

Como sugestão natural para extrair arsênio do solo, tem-se uma samambaia aditivada que, recentemente, pesquisadores norte-americanos denominaram de hiperacumulador. Essa samambaia concentra em sua folhagem até 126 mais arsênio do que a quantidade encontrada no solo. É certo que esse trabalho encontra-se em fase inicial, mas ressalta a nova tendência na pesquisa cientifica, para o uso de biorremediadores.

$\mathrm{O}$ trabalho foi realizado em área agrícola onde são seguidos à risca, normas de aplicação de pesticidas e fertilizantes e, mesmo asssim, como pôde ser observado, a água subterrânea encontra-se contaminada por arsênio. Desta forma, como proposta de remediação, procurou-se eliminar, em pequena escala, arsênio da água que é consumida por pequenos sitiantes.

$O$ uso de ferro na forma de lã de aço mostrou-se eficiente na retenção de arsênio, somando-se a facilidade de aplicação em filtros caseiros. 


\section{REFERÊNCIAS BIBLIOGRÁFICAS}

ABERNATHY, J. R. (1983) Role of arsenical chemicals in agriculture. In: Arsenic. New York, Van Nostrand Reinhold. 129 p.

ABRAMOVAY, R. (1999) O tortuoso caminho da sustentabilidade: tendências recentes da agricultura na região Sul. In:_. Agenda 21 - Área temática: Agricultura Sustentável. Consórcio Museu Emílio Goeldi. 42 p.

ADRIANO, D. C. (1986) Trace elements in the terrestrial environment. New York, Springer-Verlag. $533 \mathrm{p}$.

AGGETT, J.; ASPELL, A. C. (1976) Determination of arsenic (III) and total arsenic by the silver diethyldithiocarbamate method. Analyst, v. 101, p. 912.

ALCOVER NETO, A. (1991) Evolução supérgena das rochas carbonatiticas ricas em apatita do complexo alcalino Juquiá, São Paulo. São Paulo, 131 p. Dissertação (Mestrado) - Instituto de Geociências, Universidade de São Paulo.

ANDERSON, M. A.; FERGUSON, J. F.; GAVIS, J. (1975) Arsenate adsorption on amorphous aluminum hydroxide. Journal Colloid Interface Science. v. 54, p. 391-399.

AMERICAN WATER WORKS ASSOCIATION (1992) Standardized protocal for the evaluation of $G A C$. Denver, Elmsford. $156 \mathrm{p}$. 
ASSOCIAÇÃO BRASILEIRA DE GEOLOGIA DE ENGENHARIA (1981)

Ensaios de permeabilidade em solos - primeira tentativa - Boletim Técnico. $A B G E$, n. 4.13 p.

BELZILE, N.; TESSIER. A. (1990) Interactions between arsenic and iron oxyhydroxides in lacustrine sediments. Geochemistry and Cosmology Acta. v. 54 p. 103-109.

BEVERIDGE, A; PICKERING, W. F. (1980) Influence of humate-solute interactions on aqueous heavy metals ion levels. Water Air Soil Pollutant. v. 14, p. 171-185.

BHUMBLA, D.K.; KEEFER, R. F. (1994) Arsenic mobilization and biovailability in soil. In: _. Arsenic in environmental: cycling and characterzation. New York, John Wiley \& Sons. 430 p.

BORGGAARD, O. K.; JORGENSEN, S. S.; MOBERG, J. P.; RABEN-LANGE,B. (1990) Influence of organic matter on phosphate adsorption by aluminium and iron oxides in sandy soils. Journal Soil Science, v. 41, p. 443-449.

BOYER, H. E; GALLY, D. (1998) Retention of arsenic in constituents with different structures. Metals \& Materials. v.57, p. 233-239.

BRASIL, LEIS, DECRETOS (1989) Dispõe sobre a produção, embalagem, rotulagem, transporte, armazenamento, comercialização, propaganda comercial, importação, destino final dos resíduos, embalagens, registro, controle, inspeção e fiscalização do uso de agrotóxicos, seus componentes 
afins e outras providências. In: Diário Oficial da União, Brasília, 12 de julho de 1989. (Lei n 7.802 de 11 de julho de 1989).

BRASIL, LEIS, DECRETOS (1992) Padrões de potabilidade de águas para o consumo humano.In: Diário Oficial da União, Brasilia, 23 de janeiro de 1992 Portaria $n^{\circ} 36$ de 19 de janeiro de 1990.

BRASIL, LEIS, DECRETOS (1998) Limites máximos de tolerância para contaminantes inorgânicos em alimentos. Diário Oficial da União, Brasília, 24 de setembro de 1998 - Portaria n 685 de 27 de agosto de 1998, parte I.

BRITISH PHARMACOPOEIA (1973) Limit test for arsenic. London, McGraw. p. A74-A75. appendix VI.

BROOKINS, D. G. (1988) Eh-pH diagrams for geochmistry. New York, SpringerVerlag. $176 \mathrm{p}$.

BUENO, L. (1999) Análise de radionuclideos naturais e chumbo em produtos alimentícios e dietas. São Paulo, 87 p. Dissertação (Mestrado) - Instituto de Pesquisas Energéticas e Nucleares, IPEN.

CAMPOS, V. (1996) Estudo da fixação de fosfato em minerais representativos de solos com características ácidas. São Paulo, 84 p. Dissertação (Mestrado) Instituto de Geociências, Universidade de São Paulo. 
CANELA, M, C. (1995) Determinação de mercúrio a nível traço: aplicação em amostras de interesse ambiental. Campinas, 79 p. Dissertação (Mestrado)Instituto de Química, Universidade Estadual de Campinas.

CELESTE, M. F. (1986) Estudo dos processos de contaminação por praguicidas organoclorados em ambiente aquático - o caso da represa de Ribeirão do Lobo (Brotas - Itirapina, São Paulo). São Carlos, 252 p. Dissertação (Mestrado), Universidade Federal de São Carlos.

CHENG, Z. (2000) Inhibition of growth of human immunodeficiency virus in vitro by arsenic trioxide and dimethylarsinic acid [online] San Diego, Disponivel: http://phys4.harvard.edu/ wilson/SanDiego2000/Abstracts11.html [capturado em 26 de janeiro de 2001].

CHILVER, D. C.; PETERSON, P. J. (1987) Lead, mercury, cadmium and arsenic in the environment. New York, John Wiley \& Sons, 347 p.

CHROTOWSKI, P.; DURDA, J. L.; EDELMANN, K. G. (1991) The use of natural processes for the control of chromium migration. Remediation, v. 12, p. 341351

COMPANHIA DE SANEAMENTO BÁSICO DO ESTADO DE SÃO PAULO (1994) Compilação de padrões ambientais. São Paulo, CETESB. 6 p.

COMPANHIA DE SANEAMENTO BÁSICO DO ESTADO DE SÃO PAULO (1999) Relatório de qualidade das águas: Interiores do Estado de São Paulo, São Paulo, CETESB. 391 p. 
CORTOPASSI, J. E.; DUNN, M. J.; KEPNER, B. E.; JOHN, M. (2000) Removal of arsenic using composite metal oxide particles from drinking waters in West Bengal, India. [online] San Diego. Disponível: http://phys4.harvard.edu/ wilson/SanDiego2000/Abstracts11.html [capturado em 26 de janeiro de 2001]

CUSTODIO, E.; LLAMAS, M. R. (1983) Hidrologia subterrânea. 2 ed. Barcelona, Omega. $2 \mathrm{v}$.

DEUEL, L. E.; SWOBODA, A R. (1972) Arsenic solubility in a reduced environment. Soil Science Society American Proceedings, v. 36, p. 215-218.

EMPRESA BRASILEIRA DE PESQUISA AGROPECUÁRIA (1997) Manual de métodos de análise de solo. Brasília, Centro Nacional de Pesquisa de Solos. $212 \mathrm{p}$.

EVANS, P. C. (1996) Brasil: Região Sudeste. Paraná, Asa. 127 p.

EWALD, E.; GREENE, D.; DRESCHER, A.; GADGIL, A. (2000) Low-cost UV disinfection of surface water in Bangladesh [online] p. 30. Disponível: http://phys4.harvard.edu/ wilson/arsenic_conf.html [capturado em 26 de janeiro de 2001].

FAUST, S. D. ; ALY, O. M. (1999) Chemistry of water treatment. 2 ed. New York, Lewis Publishers. 581 p.

FERGUSON, J. F.; GAVIS, J. (1972) A review of the arsenic cycle in natural waters. Water Research, v. 6, p. 1259-1274. 
FERREIRA, C. R. (1999) Defensivos agrícolas. Informações Econômicas, v. 29, p. 43-45.

FOLHA DE SÃO PAULO (1998) Água com arsênio envenena 18 milhões (Tragédia na Ásia - habitantes de Bangladesh e Bengala Ocidental bebem há 25 anos produto contaminado que causa câncer). Caderno 14 Mundo/ sextafeira, 13 de novembro de 1998 por Marcio Aith.

GABE, U. (1998) Teor e disponibilidade para soja de micronutrientes e elementos potencialmente tóxicos em fertilizantes minerais e calcário. Piracicaba, 84 p. Tese (Doutoramento), Escola Superior de Agricultura Luiz de Queiroz, Universidade de São Paulo.

GABE, U.; RODELLA, A. A. (1999) Trace elements in brazilian agricultural limestones and mineral fertilizers. Communications in Soil Science and Plant Analysis, v.30, p. 605-620.

GARDNER, M; RAVENSCROFT, J. (1991) The behaviour of copper complexation in rivers and estuaries: two studies in north East England. Chemosphere, v. 23, p. 695-713.

GIESY, J. P. (1984) Metal binding capacity of soft, acid, organic-rich waters. Toxicology Environment Chemistry, v. 6, p. 203-224.

GILLMAN, G. P. (1979) A proposed method the measurement of exchange properties of high-weathered soils. Australian Journal of Soil Research, v. 17, p. $129-141$. 
GODGUL, G.; SAHU, K. C. (1995) Chromium contamination from chromite mine. Environmental Geology, v. 25, p. 251-257.

GOVERNO DO ESTADO DE SÃO PAULO (1986) Carta geológica do Estado de São Paulo (1: 50 000). Folha de Jundiaí. Relatório Final. Rio Claro, $2 \mathrm{v}$.

GOVERNO DO ESTADO DE SÃO PAULO (1999) Mapa pedológico do Estado de São Paulo (1:500 000). Folha 4 - Sudeste de Jundiaí. Campinas: Embrapa/IAC.

GUEYE, P. A. (1998) Estudo das alternativas de transporte para a explotação de jazida de fosfato no Senegal. Campinas, 62 p. Dissertação (Mestrado) Instituto Geociências, Universidade Estadual de Campinas.

GORBY, S. M. (1994) Arsenic in human medicine. In: NRIAGU, J.O. Arsenic in environmental. New York, John Wiley \& Sons. 430 p.

HAMASWAMI, A.; ISLEYEN, M.; TAWACHSUPA, S. (2000) Zero-valent iron for treatment on high arsenic water [online] San Diego. Disponivel: http://phys4.harvard.edu/ wilson/SanDiego2000/abstracts11.html [capturado em 26 de janeiro de 2001]

HARBEN,P. W.; BATES, R. L. (1990) Industrial minerals geology and world deposits. In:_. Phosphate rock. London, Metal Bulletin. 394 p.

HATHAWAY, S. W; RUBEL JUNIOR, F. (1993) Removing Arsenic from drinking water. Research and Technology. v. 57, p. 61-65. 
HUTTON, M; SYMON, C. (1986) The quantities of cadmium, lead, mercury and arsenic intering the U. K. environment from human activities. The Science of the Total Environment, v. 47, p. 129-150.

INSTITUTO AGRONÔMICO DE CAMPINAS (2000) Dados meteorológicos de Jundiai no periodo de 1990 a 2000. Jundiaí, IAC/Estação Experimental de Agronomia de Jundiaí. $3 \mathrm{p}$.

INDUSTRIES CHIMIQUES DU SÉNÉGAL (1999) La composition chimique et minéralogique de l'apatite de Tobène. Rapport Scientifique. Tobene, ICS. 12 p.

INTERNATIONAL AGENCY FOR RESEARCH ON CANCER (1980) Monographs on the evaluation of the carcinogenic risk of chemical to man: some metals and metallic compounds. Lyon, IARC. $2 \mathrm{v}$.

KABATA-PENDIAS, A.; PENDIAS, H. (1984) Trace elements in soils and plants. New York, Boca Raton. 315 p.

KHAIR, A.; AZAD, A. K.; PAUL, G. N. (2000) Arsenic removal from drinking water by low cost materials. [online] p. 26. Disponível: http://phys4.harvard.edu/ wilson/arsenic_conf.htm] [capturado em 26 de janeiro de 2001].

KING, R. B. (1995) Encyclopedia of inorganic chemistry. In: ZINGARO, R. A. Arsenic: inorganic chemistry. New York, John Wiley \& Sons, $4 \mathrm{v}$. 
KOSMUS, W. A pocketsize device to measure arsenic in water (2000) [online] San Diego.Disponivel:http://phys4,harvard.edu/ wilson/SanDiego2000/Abstracts1 1.html [capturado em 26 de janeiro de 2001].

LIVESEY, N.T.; HUANG, P. M. (1981) Adsorption of arsenate by soils and its relation to selected chemical properties and anions. Soil Science, v. 131, p. 8894.

MACRAE, R.; ROBINSON, R. K.; SADLER, M. J. (1993) Encyclopaedia of food science, food technology and nutrition. New York, Academic Press. 8 v.

MANNING, B. A.; GOLDBERG, S. (1996) Modeling competitive adsorption of arsenate with phosphate and molybdate on oxide minerals. Soil Science American Journal. v. 60, p. 121-131.

MARSCHNER, H. (1995) Mineral nutrition of higher plants. 2 ed. London, Academic Press, 889 p.

MARTINS, M. C. (1994) Quantificação dos parâmetros monocíclicos e controle químico da ferrugem do pessegueiro. Piracicaba, 67 p. Dissertação (Mestrado) - Escola Superior de Agricultura Luiz de Queiroz, Universidade de São Paulo.

MASSCHELEYN, P. H.; DELAUNE, R. D.; PATRICK, W. H. (1991) Effect of redox potential and $\mathrm{pH}$ on arsenic speciation and solubility in a contaminated soil. Environmental Science and Technology, v. 25, p. 1414 1419. 
MATTIAZZO-PREZOTTO, M. E. (1994) Comportamento de cobre, cádmio, cromo, níquel e zinco adicionados a solos de clima tropical em diferentes valores de pH. Piracicaba, 197 p. Tese (Livre Docência)-Escola Superior de Agricultura Luiz de Queiroz, Universidade de São Paulo.

MCBRIDE, M. B. (1989) Reaction controlling heavy metal solubility in soils. Advances in Soil Science, v. 10, p. 1-56.

MCCONNELL, R.; HENAO, S.; NIETO, O.; ROSENSTOCK, L.; TRAPÉ, A. Z; WESSELING, C. (1993) Pesticides. In: FINKELMAN, J; COREY, G.; CALDERON, R. Environmental epidemiology: a project for Latin America and the Caribbean. Washington, PAHO. 342 p.

MILLER JUNIOR, G. T. (1990) Living in the environment. Belmont, Wadsworth. $620 \mathrm{p}$.

MOK, W. M.; WAI, C. M. (1994) Mobilization of arsenic in contaminated rivers waters. In: NRIAGU, J.O. Arsenic in environmental. New York, John Wiley \& Sons. $430 \mathrm{p}$.

MOORE, J. W. (1991) Inorganic contaminants of surface water. New York, Springer Verlag. $156 \mathrm{p}$.

MUNSELL SOIL COLOR CHARTS (1994) Munsell soil color charts. Revised Edition. New York, Macbeth Division of Kollmorgen Instruments Corporation. 
NIKOLAIDIS, N. P. (2000) Arsenic remediation technology-AsRT [online]. University of Connecticut, p.1-8. Disponivel: http://www.eng2.uconn.edu/cee/ bio/Nikolaidis.html [capturado em 26 de janeiro de 2001].

OLIVEIRA, J. B.; JACOMINE, P. K. T.; CAMARGO, M. N. (1992) Classes gerais de solos do Brasil: guia auxiliar para seu reconhecimento. Jaboticabal, Fundag. $201 \mathrm{p}$.

OSA, R. H. (1994) Mercury atmospheric processess: a synthesis report. In: Workshop Proceedings, Flórida, 17 p.

OSCARSON, D. W;; HUANG, P. M.; LIAW, W. K.; HAMMER, U. T. (1983) Kinetics of oxidation of arsenite by various manganese dioxides. Soil Science American Journal, v. 47, p. 644-648.

PARFITT, R. L. (1989) Phosphate reactions with natural allophane, ferrihydrite and goethite. Journal Soil Science, v. 40, p. 359-369.

PERYEA, F. J. (1991) Phosphate-induced release of arsenic from soils contaminated with lead arsenate. Soil Science American Journal, v.55, p. 1301-1306.

PIERCE, M. L.; MOORE. C. B. (1982) Adsorption of arsenite and arsenate on amorphous iron hydroxide. Water Research, v.16, p. 1247-1253.

PORCELlA, D.; HUCKABEE, J.; WHEATLEY, B. (1995) Mercury as a global pollutant. London, Kluwer Academic Publishers. $1336 \mathrm{p}$. 
PRISM SULPHUR CORPORATION (1999) From Canada to your World. Sulphur Survey Manual. Alberta, $9 \mathrm{p}$.

PREFEITURA DO MUNICÍPIO DE JUNDIAÍ (1998) Carta hidrográfica do rio Jundiaí-Mirim (1:50 000). Folha de Jundiaí, Jundiaí.

RAIJ, B.; QUAGGIO, J. A. (1983) Métodos de análise de solo para fins de fertilidade. Campinas, Boletim Técnico. Instituto Agronômico de Campinas, n. 81. p. 31 .

RODRIGUES, P. R. P. (1997) O benzotriazol como inibidor de corrosão para ferro e ligas ferrosas em meios ácidos. São Paulo, 219 p. Tese (Doutoramento)Instituto de Química, Universidade de São Paulo.

ROY, W. R.; HASSETT, J. J.; GRIFFIN, R. A (1986) Competitive coefficients for the adsoption of arsenate, molybdate and phosphate mixtures by soils. Soil Science Society American Journal. v. 50, p. 1176-1182.

RENZONI, A.; MATTEI, N.; LARI, L.; FOSSI, M. C. (1994) Cancer risks from arsenic in drinking water. In: SMITH, A. $\mathrm{H}$ et al. Contaminants in the environment. Lewis Publishers, Florida. 286 p.

SALOMONS, W.; FÖRSTNER, U. (1984) Metals in the hydrocicle. Germany, Springer Verlag. 449p.

SANYAL. S. K; DE DATTA, S. H. (1991) Chemistry of phosphorus transformations in soils. Advances in Soil Science, v. 16, p. 1-20. 
SILVA, S. R. L. (1994) Contaminação por mercúrio em ribeirinhas e índias da Amazônia: transferência mãe-filho. Brasília, 102 p. Dissertação (Mestrado), Universidade de Brasília.

SMITH, L A.; MEANS, J. L.; CHEN, A.; ALLEMAN, B.; CHAPMAN, C. C.; TIXIER JUNIOR, J. S.; BRAUNING, S. E.; GAVASKAR. A. R.; ROYER, M. D. (1995) Remedial options for metals-contaminated sites. Lewis Publishers, Boca Raton. 221p.

TAKAMATSU, T.; AOKI, H.; YOSHIDA, T. (1982) Determination of arsenate, monomethylarsonate, and dimethylarsinate in soil polluted with arsenic. Soil Science. v. 133, p. 239-246.

TIGLEA, P. (1995) Cromo em alimentos. São Paulo, 56 p. Dissertação (Mestrado)Instituto de Química, Universidade de São Paulo.

TÜMPLING, W. V. J.; WILKEN, R. D.; EINAX, J. (1993) Mercury contamination in the Pantanal Area, Brazil. In: Proceeding of the International Conference on Heavy Metals in the Environmental. Toronto, $2 \mathrm{v}$.

UNITED STATES ENVIRONMENTAL PROTECTION AGENCY (1999) Status of pesticides in registration and special review [online] USEPA, p. 462 Disponível: http://www.epa.gov/oppsrrd/rainbow [capturado em 19 de dezembro de 2000].

WALKLEY, A.; BLACK, J. A. (1934) An examination of the degtjareff method for determining soil organic matter, and proposed modification of the chromic acid titration method. Soil Science, v. 37, p. 29-38. 
WELCH, A. H.; LICO, M. S.; HUGHES, J. L. (1988) Arsenic in groundwater of the Western United States. Groundwater, v.36, p. 333-347.

WOOLSON, E. A; AXLEY, J. H.; KEARNEY, P. C. (1971) The chemistry and phytotoxicity of arsenic in soils: I. contaminated field soils. Soil Science Society American Proceedings, v.35, p. 938-943.

WORLD HEALTH ORGANIZATION (1984) Guidelines for drinking water quality. Geneva, WHO, p. 13-21.

WORLD HEALTH ORGANIZATION (1995) Environmental health criteria 165 inorganic lead. Geneva, WHO, p. 25-35.

WORLD HEALTH ORGANIZATION (1999) Guías para la calidad del agua potable. 2. ed. Ginebra, OMS. $40 \mathrm{p}$.

YUAN, G.; LAVKULICH, M. (1994) Phosphate sorption in relation to extractable iron and aluminum in spodosols. Soil Science Society American Journal, v. 58: p. 343-346. 